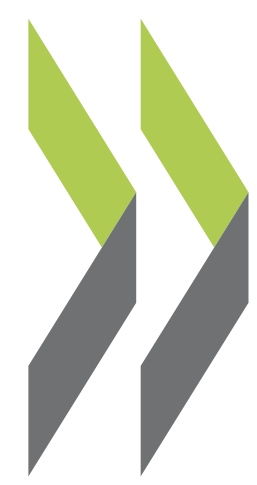

OECD Economics Department Working Papers No. 1545

Adapting business framework conditions to deal with disruptive technologies in Denmark
Mikkel Hermansen,

Valentine Millot 


\section{ADAPTING BUSINESS FRAMEWORK CONDITIONS TO DEAL WITH DISRUPTIVE TECHNOLOGIES IN DENMARK}

ECONOMICS DEPARTMENT WORKING PAPERS No. 1545

\section{By Mikkel Hermansen and Valentine Millot}

OECD Working Papers should not be reported as representing the official views of the OECD or of its member countries. The opinions expressed and arguments employed are those of the author(s).

Authorised for publication by Isabell Koske, Deputy Director, Country Studies Branch, Economics Department.

Document available in pdf format only.

All Economics Department Working Papers are available at www.oecd.org/eco/workingpapers.

JT03445452 
OECD Working Papers should not be reported as representing the official views of the OECD or of its member countries. The opinions expressed and arguments employed are those of the author(s).

Working Papers describe preliminary results or research in progress by the author(s) and are published to stimulate discussion on a broad range of issues on which the OECD works.

Comments on Working Papers are welcomed, and may be sent to OECD Economics Department, 2 rue André Pascal, 75775 Paris Cedex 16, France, or by e-mail to eco.contact@oecd.org.

All Economics Department Working Papers are available at www.oecd.org/eco/workingpapers.

This document and any map included herein are without prejudice to the status of or sovereignty over any territory, to the delimitation of international frontiers and boundaries and to the name of any territory, city or area.

The statistical data for Israel are supplied by and under the responsibility of the relevant Israeli authorities. The use of such data by the OECD is without prejudice to the status of the Golan Heights, East Jerusalem and Israeli settlements in the West Bank under the terms of international law.

On 25 May 2018, the OECD Council invited Colombia to become a Member. At the time of preparation the deposit of Colombia's instrument of accession to the OECD Convention was pending and therefore Colombia does not appear in the list of OECD Members and is not included in the OECD zone aggregates.

\section{(C) OECD (2019)}

You can copy, download or print OECD content for your own use, and you can include excerpts from OECD publications, databases and multimedia products in your own documents, presentations, blogs, websites and teaching materials, provided that suitable acknowledgment of OECD as source and copyright owner is given. All requests for commercial use and translation rights should be submitted to rights@oecd.org. 


\section{Abstract / Résumé \\ Adapting business framework conditions to deal with disruptive technologies in Denmark}

Danish firms are close to the technological frontier compared to other OECD countries, making the introduction of new - potentially disruptive - technologies key to boost productivity growth. Despite a high level of digitalisation and good framework conditions, aggregate productivity growth in Denmark has been only average compared to other advanced OECD countries and lags behind in less knowledge-intensive service industries. Policy needs to embrace innovative technologies by leaning against attempts to discourage or exclude them and by tackling unintended or outmoded obstacles in legislation and regulation. Analysis based on Danish firm-level data suggests that digital adoption through investment in ICT capital increases firm productivity and contributes to business dynamics and firm growth. Improving economic incentives for such investment as well as facilitating adoption of new business models require a shift of taxation away from capital and labour income. Ensuring supply of the right skills and maintaining effective upskilling will help workers cope with disruptive changes and ensure that economic growth benefits all.

JEL codes: E24, H25, L40, L50, O16, O33, O38

Keywords: productivity, competition, taxation, innovation, digitalisation, skills, disruption

This Working Paper relates to the 2019 OECD Economic Survey of Denmark (www.oecd.org/eco/surveys/economic-survey-denmark.htm).

$* * * * * * * * * * * * * * * * * * * * * * * * * * * * * * * * * * * * * * * * *$

\section{Adapter les conditions cadres applicables aux entreprises pour faire face aux technologies de rupture en Danemark}

Les entreprises danoises sont proches de la frontière technologique par rapport à celles des autres pays de l'OCDE, ce qui rend l'introduction de technologies nouvelles - potentiellement porteuses de bouleversements - essentielle pour doper la croissance de la productivité. Malgré un niveau élevé de déploiement du numérique et des conditions cadres favorables, la croissance de la productivité globale au Danemark est restée moyenne par rapport aux autres pays avancés de l'OCDE et affiche un retard dans les secteurs des services à plus faible intensité de savoir. L'action des pouvoirs publics doit favoriser l'adoption des technologies innovantes en contrant les tentatives visant à les freiner ou les exclure, et en levant les obstacles non voulus ou obsolètes imposés par la législation et la réglementation. L'analyse fondée sur les données au niveau des entreprises danoises révèle que l'adoption du numérique par le biais d'investissements dans les équipements TIC stimule la productivité et contribue à la dynamique et la croissance des entreprises. Pour améliorer les incitations économiques en faveur de tels investissements et favoriser l'adoption de nouveaux modèles économiques, le pays doit réorienter sa fiscalité, actuellement axée sur les revenus du capital et du travail. Assurer une offre de compétences adaptées et une valorisation efficace des qualifications aidera les travailleurs à affronter les évolutions radicales et permettra de faire en sorte que la croissance économique profite à tous.

Codes JEL : E24, H25, L40, L50, O16, O33, O38

Mots-clés : productivité, concurrence, fiscalité, innovation, numérique, compétences, rupture

Ce Document de travail a trait à l'Étude économique de l'OCDE du Danemark 2019 (http://www.oecd.org/fr/eco/etudes/etude-economique-danemark.htm). 


\section{Table of contents}

\section{Adapting business framework conditions to deal with disruptive technologies in Denmark ..........6}

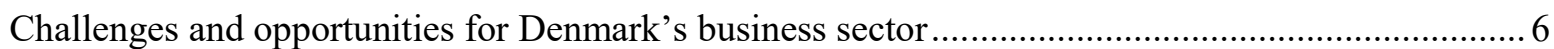

Refining competition and regulatory frameworks to promote business dynamics............................ 19

Upgrading capital markets and rebalancing taxation to boost investment ......................................25

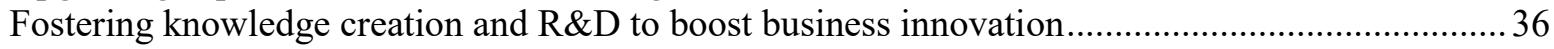

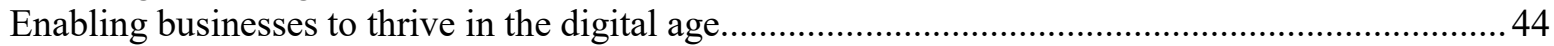

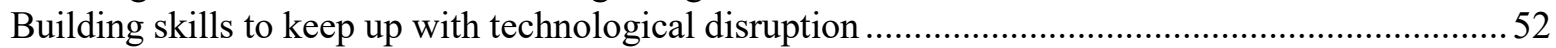

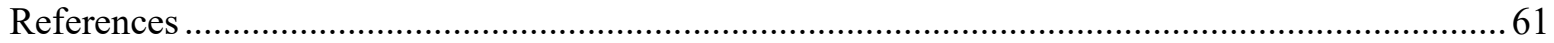

\section{Tables}

Table 1. Business services grouped by knowledge-intensity and internationalisation ........................... 14

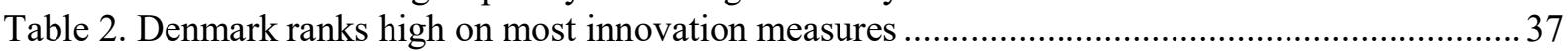

Table 3. Danish R\&D investors is strongly dominated by pharmaceutical companies ......................... 39

\section{Figures}

Figure 1. Danish firms are at the frontier in using new technologies

Figure 2. The business framework is among the most favourable across OECD countries ................... 7

Figure 3. A snapshot of the Danish economy and businesses ........................................................... 10

Figure 4. Productivity growth has slowed down in Denmark driven by services.................................. 11

Figure 5. Less knowledge-intensive services industries lag behind other countries.............................. 12

Figure 6. Productivity growth in internationalised services is showing weaknesses............................ 13

Figure 7. The gap to firms at the productivity frontier remains small in Denmark .............................. 15

Figure 8. Business dynamics has remained high compared to other countries.....................................2 20

Figure 9. Many young firms exit and those remaining employ a low share of workers.......................2 21

Figure 10. The composition of new firms has shifted towards knowledge-based and ICT services ..... 22

Figure 11. Mark-ups are stable on average, but on the rise in certain sectors .......................................2 23

Figure 12. Business investments are picking up and shifting towards intangibles ............................25

Figure 13. Corporations are accumulating financial assets despite a wide gap between return and

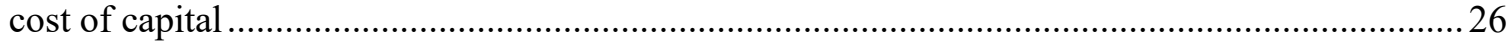

Figure 14. ICT investment is associated with higher business dynamics and higher TFP ...................2 27

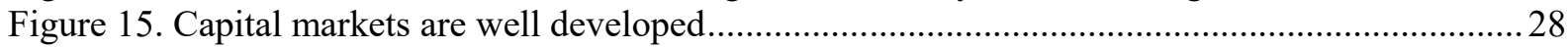

Figure 16. Debt-to-equity is low and dominated by mortgage loans ...................................................2 29

Figure 17. Denmark raises plenty of venture capital but the majority is invested abroad .......................30

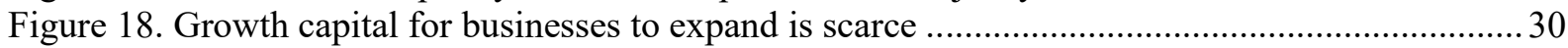

Figure 19. The tax wedge and the corporate income tax rate are close to OECD averages ..................32

Figure 20. The top marginal tax rate and dividend taxation are high and aligned.................................33

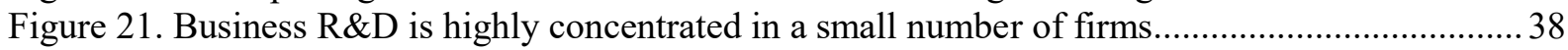

Figure 22. Denmark's patents are highly specialised in environment technologies ..............................40 
Figure 23. Denmark's relative performance in patent filings is unequal across different technological areas.

Figure 24. Information industries productivity and innovation performance relative to other sectors are lower than in most countries

Figure 25. The policy mix in public support for business R\&D increasingly relies on fiscal incentives, although they remain at a moderate level.

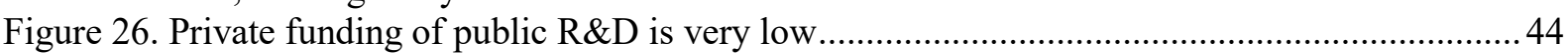

Figure 27. Adoption of digital technologies is uneven across technologies and firm size .....................45

Figure 28. Potential increase in digital adoption rate from structural policy reforms ..........................47

Figure 29. Digital access is high, but deployment of the latest technologies is low............................... 48

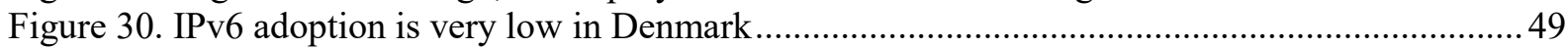

Figure 31. Denmark is a frontrunner in e-government use but lags in data openness ..........................50

Figure 32. Use of personal information on the Internet is a concern in Denmark ................................51

Figure 33. Formally defined security policies are mostly present in large firms .................................52

Figure 34. Knowledge areas and skills in shortage and surplus in Denmark .....................................5

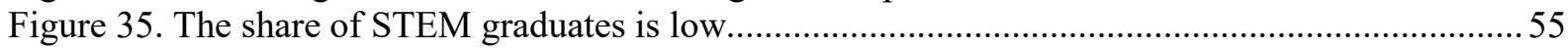

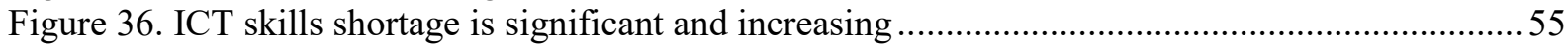

Figure 37. Labour market returns to ICT tasks are relatively low .......................................................56

Figure 38. Participation in life-long learning is high but decreasing ................................................58

Figure 39. A large proportion of foreign-born adults are highly educated, but they represent a small proportion of the total population

\section{Boxes}

Box 1. A disrupted economy? Snapshot shows characteristics close to OECD averages ...................... 8

Box 2. How to group service industries to detect weaknesses? ........................................................ 13

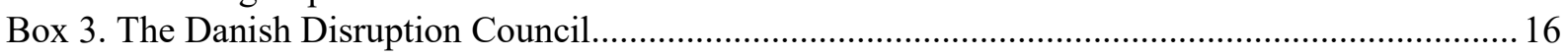

Box 4. Recent policy initiatives to enhance digitalisation and the business environment...................... 18

Box 5. ICT investment benefits business dynamics and firm productivity in Denmark .......................2 27

Box 6. Reducing the tax bias to debt finance by an allowance for corporate equity .............................. 34

Box 7. How much scope for structural reform to boost digital adoption in firms in Denmark? ............46

Box 8. Preparing for the next waves of digital innovation with the deployment of IPv6 .....................49

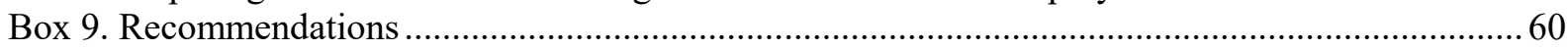




\title{
Adapting business framework conditions to deal with disruptive technologies in Denmark
}

\author{
Mikkel Hermansen and Valentine Millot ${ }^{1}$
}

\section{Challenges and opportunities for Denmark's business sector}

Businesses in Denmark, like around the world, are in the midst of a technological transformation. Compared to other OECD countries, Danish firms have been frontrunners in adopting digital technologies (Figure 1, Panel A) and extensive use of industrial robots underpins a high level of automation (Figure 1, Panel B). The economic environment is one of the most favourable to businesses, entrepreneurship and innovation across OECD countries (Figure 2). This reflects a flexible and well-functioning labour market, low regulatory barriers and high public spending on $R \& D$ among others.

Figure 1. Danish firms are at the frontier in using new technologies
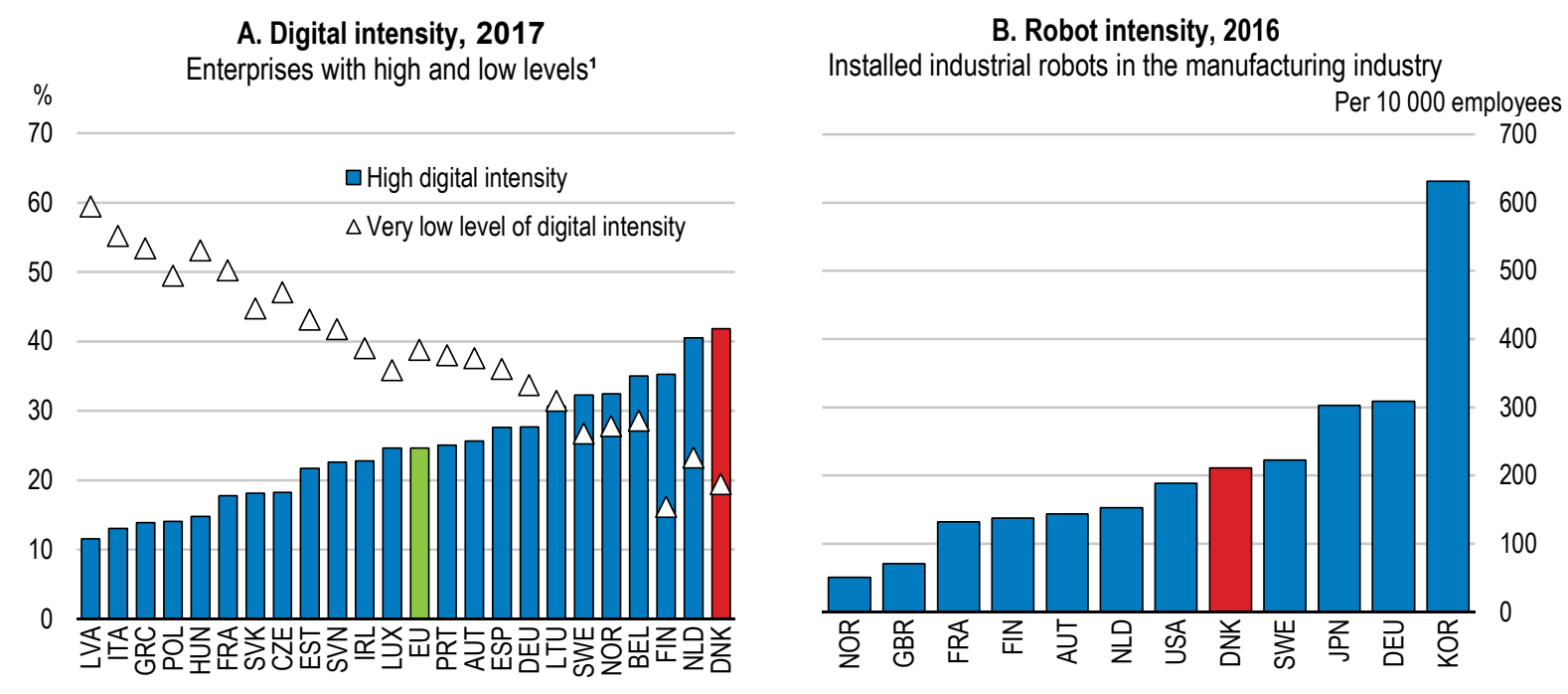

1. Share of firms using at least 7 out of 12 digital technologies (high intensity) and no more than 3 out of 12 technologies (very low level) in enterprises with 10 or more employees. Digital technologies are: usage of internet by a majority of the workers; access to ICT specialist skills; fixed broadband speed $>30 \mathrm{Mbps}$; mobile devices used by more than $20 \%$ of employed persons; has a website; has some sophisticated functions on the website; presence on social media; does e-sales for at least $1 \%$ of turnover; exploit the $\mathrm{B} 2 \mathrm{C}$ opportunities of web sales; pay to advertise on the internet; purchase cloud computing advanced services; send e-invoices.

Source: European Commission, Digital Scoreboard; International Federation of Robotics, World Robotics 2017.

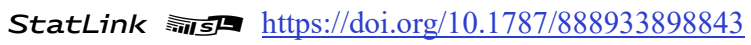

\footnotetext{
${ }^{1}$ Mikkel Hermansen and Valentine Millot are Economists in the Country Studies Branch of the OECD Economics Department. For valuable comments and suggestions the authors would like to thank OECD colleagues Pierre Beynet, Robert Ford, Caroline Klein, Patrick Lenain, Annabelle Mourougane, Alvaro Pereira, Stéphane Sorbe, Douglas Sutherland, Silvia Appelt, Philippe Larrue, Dirk Pilat, Bert Brys, Thomas Liebig, Fabio Manca, Antonio Capobianco and Serdar Celik. Consultants Valerie Smeets and Frederic Warzynski (Aarhus University) provided valuable empirical work supporting the analysis on ICT investment and firm productivity (summarised in Box 5). The paper also benefitted from comments by Sune Malthe-Thagaard and special thanks are due to Corinne Chanteloup for statistical assistance and to Stephanie Henry for editorial assistance.
} 
Figure 2. The business framework is among the most favourable across OECD countries

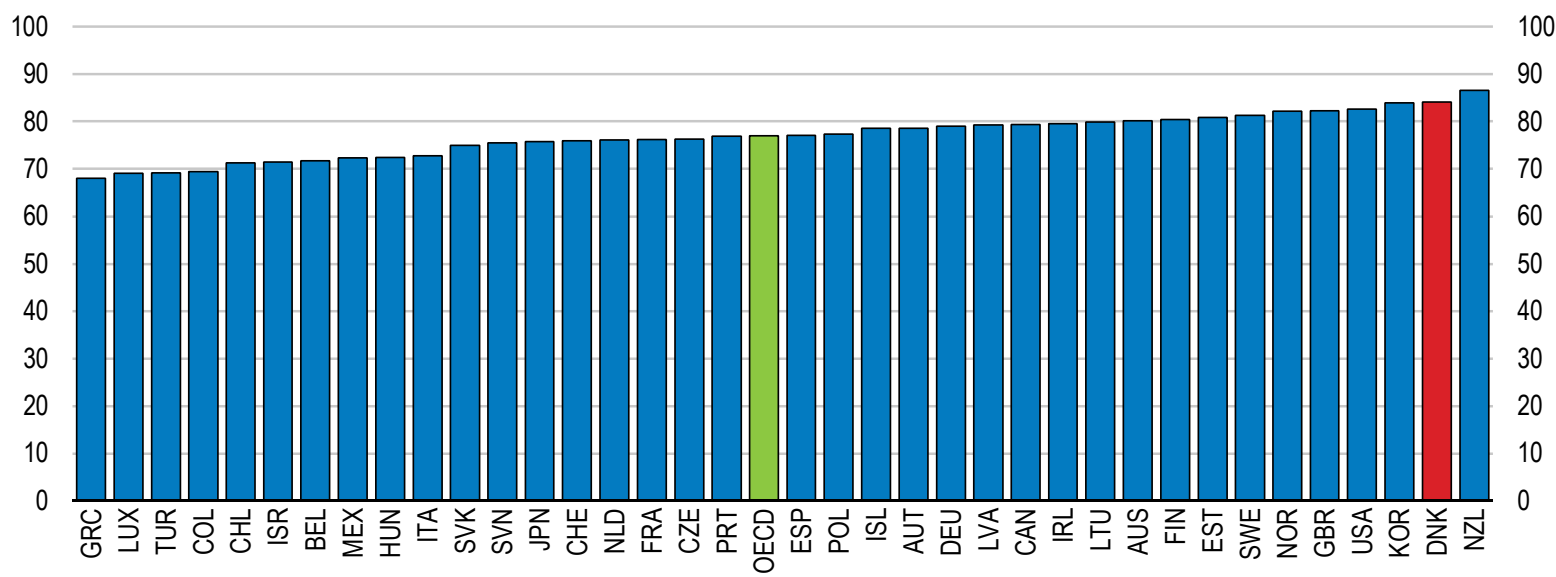

Note: The index measures the distance of each economy to the "frontier," which represents the best performance observed on each of the indicators across all economies. The distance to frontier is reflected on a scale from 0 to 100 , where 0 represents the lowest performance and 100 represents the frontier.

Source: World Bank, Doing Business 2018.

StatLink त्ञाs https://doi.org/10.1787/888933898862

A strong business sector with the capacity to exploit opportunities in globalised markets is key to sustain Denmark's well-performing welfare model. As advanced technologies and digitalisation continue to evolve, businesses are facing new opportunities as well as new challenges. Disruptions that reduce or even wipe out the market shares of incumbent firms or render some production processes or services obsolete are likely to become more frequent. For example, a smartphone app to facilitate electronic payments (MobilePay) was used by more than half of the population in Denmark just three years after its introduction and processed more than 170 million payments in 2016 (Danmarks Nationalbank, $2017_{[1]}$ ). At the same time, the scope for incumbent firms to prevent entries of new firms can rise as technologies facilitate economies of scale, while disruptors themselves can become dominating through winner-takes-most dynamics.

The size and type of disruptions (or shocks) to the economy are likely to be different compared to previous episodes of technological change and globalisation. First, the reduced costs of advanced technologies enables their wider diffusion, including to SMEs (such as cloud computing and online sales to consumers), even though this requires complementary investments in skills, process changes and innovation. Second, the ability to combine new advanced technologies (such as sensors, advanced robotics and 3D printing), new processes (such as data-driven production and artificial intelligence) and new business models (exploiting mass customisation, the collaborative and platform economies) enables new types of applications. This is expected to trigger complex changes in the way goods and services are produced and consumed (OECD, 2018 $\left.8_{[2]}\right)$, widening the scope and markets for doing business and inducing firms either to capture large returns from business openings or to miss out.

In Denmark, a successful cluster of robotic businesses and a startup hub have emerged in Odense, initially fostered by robotic welding in a now closed shipyard and successful 
collaboration with nearby University of Southern Denmark. While major impacts of disruptive technologies are not yet visible at the aggregate level (Box 1), the Government needs to act proactively by adjusting policies and regulatory framework conditions to ensure that households benefit the most from new technologies. In a nutshell, the challenge is to deliver inclusive growth by creating conditions for firms to boost productivity, while maintaining high employment and job quality to enhance wellbeing. This chapter takes a broad view on the Danish business sector and discusses how policies need to adjust for society to make the most of disruptive technologies.

A future with larger uncertainties will also require adjustments of labour market policies as disruptions can be painful for workers, requiring additional support. In this respect, the Danish labour market is in a favourable position as it combines high flexibility with ample passive and active support, including high participation in lifelong learning. Nevertheless, reforms are needed to improve cost-efficiency and better include rising non-standard work in protection systems (see Key Policy Insights).

Box 1. A disrupted economy? Snapshot shows characteristics close to OECD averages

\section{Key characteristics of the Danish economy and businesses}

- The industrial structure is close to the OECD average (Figure 3, Panel A). Public and private services account for more than three quarters of economic activity, wholesale and retail trade as well as financial and insurance activities being proportionally more important than in neighbouring countries.

- Agriculture and fishing represent a small share of total activity, yet arable and cropland cover more than half of total land area, the highest share across OECD countries, and more than $20 \%$ of total greenhouse gas emissions arise from agriculture. Still, the technological advancement in agriculture is high and productivity growth has been substantial compared to other sectors.

- Oil and gas production from the North Sea has peaked and with lower oil prices, related energy tax revenue has declined from more than $1 \%$ until 2013 to $0.2 \%$ of GDP in 2017.

- The firm size structure is similar to Sweden and Finland (Panel B). Small and medium-sized firms (less than 250 employees) account for around $60 \%$ of business sector activity, slightly more than in larger countries like Germany and France. Micro-firms (1-9 employees) represents a relatively small share, reflecting that Denmark has one of the lowest self-employment rates (9\%) across OECD countries. 
- Employment in manufacturing has declined substantially over recent decades as in most advanced countries, while it has increased in services with the exception of public administration (Panel C).

- The public sector absorbs almost $30 \%$ of employment, more than in other OECD countries, but similar to the other Nordics. Gender differences across occupations prevails with women filling more than two thirds of public sector jobs (see Key Policy Insights). 


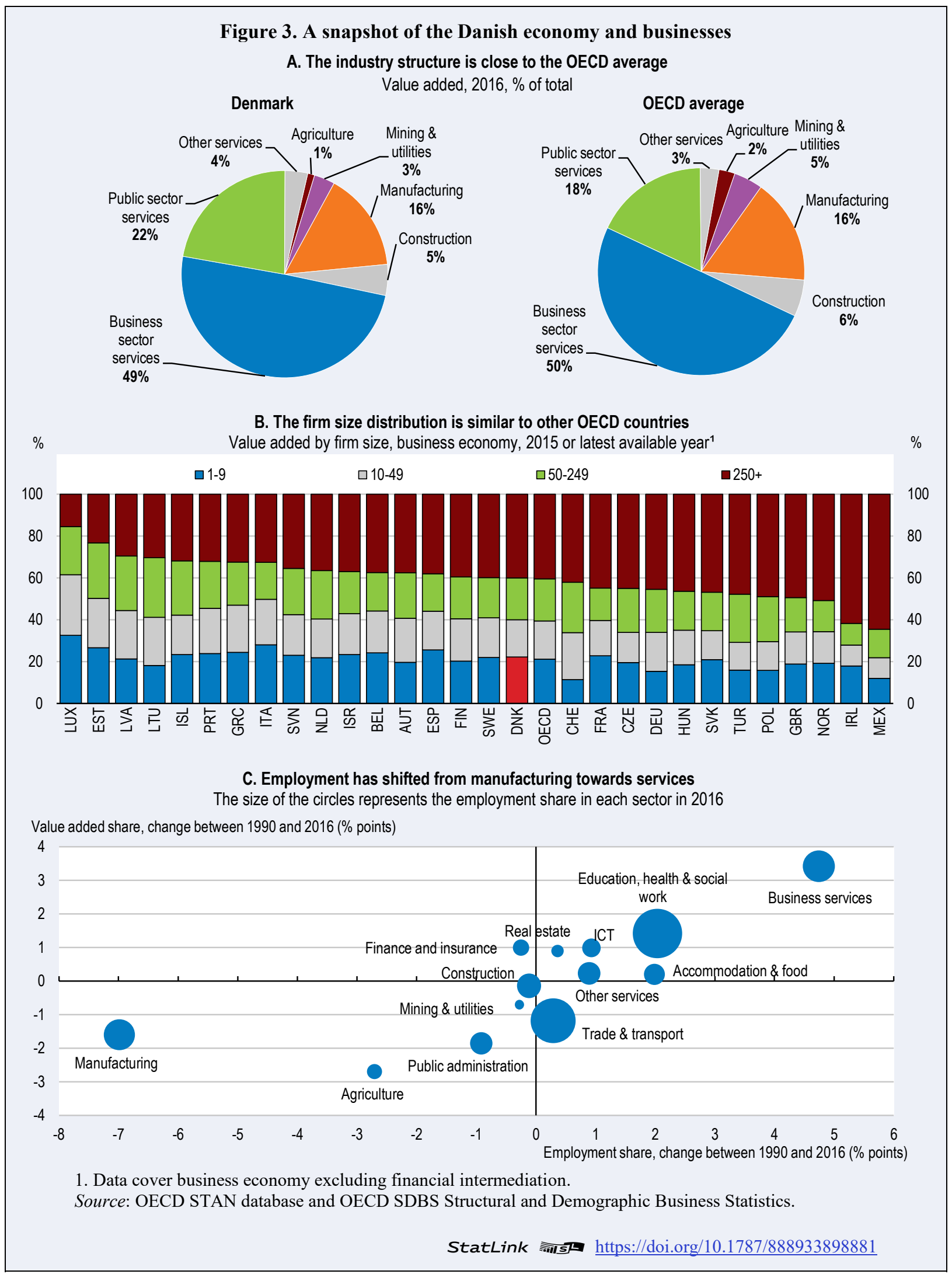




\section{Productivity growth lags behind in less knowledge-intensive services}

Despite widespread digitalisation and favourable conditions for doing business, productivity growth has weakened in Denmark. In the business sector, productivity growth has slowed down from more than $2 \%$ per year in the 1990 s to around $0.7 \%$ per year since 2010 (Figure 4, Panel A). This may reflect that the productivity level is high and pushing the frontier further becomes increasingly difficult (Gordon, 2012 $\left.{ }_{[3]}\right]$. Moreover, Denmark has not lost ground to neighbouring countries since most advanced countries have experienced a similar slowdown (Figure 4, Panel B). Private sector services have been the main driver of the slowdown in Denmark, with the exception of the ICT sector. Moreover, mining and utility has also dragged down aggregate productivity growth despite its relatively small share of the economy (Box 1), reflecting declining extraction of oil and gas in the North Sea as resources are being depleted.

Figure 4. Productivity growth has slowed down in Denmark driven by services

Average annual growth in labour productivity
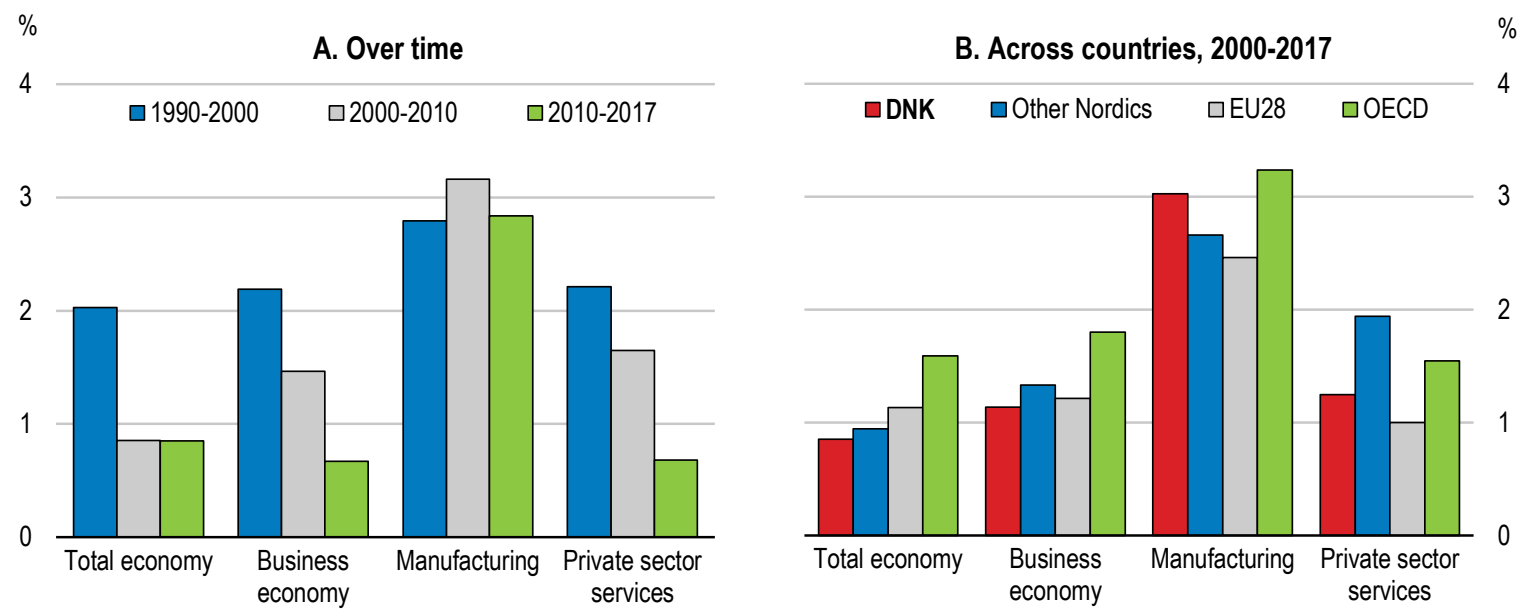

Note: Business economy covers non-agriculture business sector excluding real estate. Other Nordics is a simple average across Finland, Norway and Sweden; OECD is a simple average across 25 OECD countries with available data.

Source: OECD Productivity database.

StatLink त्राs https://doi.org/10.1787/888933898900

Productivity growth has been particularly weak in less knowledge-intensive services and lags behind the other Nordics (Figure 5). Less knowledge-intensive services comprise traditional services with a high content of non-routine manual labour such as wholesale and retail trade, land transport, accommodation and food services (Box 2). By contrast, in knowledge-intensive services, typically with a high share of tertiary graduates and/or high $R \& D$ activity, productivity growth has been stronger than in most neighbouring countries. However, the impressive productivity growth in knowledge-intensive services is largely driven by more than $15 \%$ average annual growth in telecommunication and air transport over the period 2000-2015 (Figure 5). Productivity growth in these sectors is difficult to measure since technological developments have boosted quality and at the same time lowered costs and prices substantially. Nonetheless, excluding the two industries does not change the finding that weak productivity is concentrated in less knowledge-intensive services, both over time and compared to other countries. 
Figure 5. Less knowledge-intensive services industries lag behind other countries

Average annual growth in labour productivity
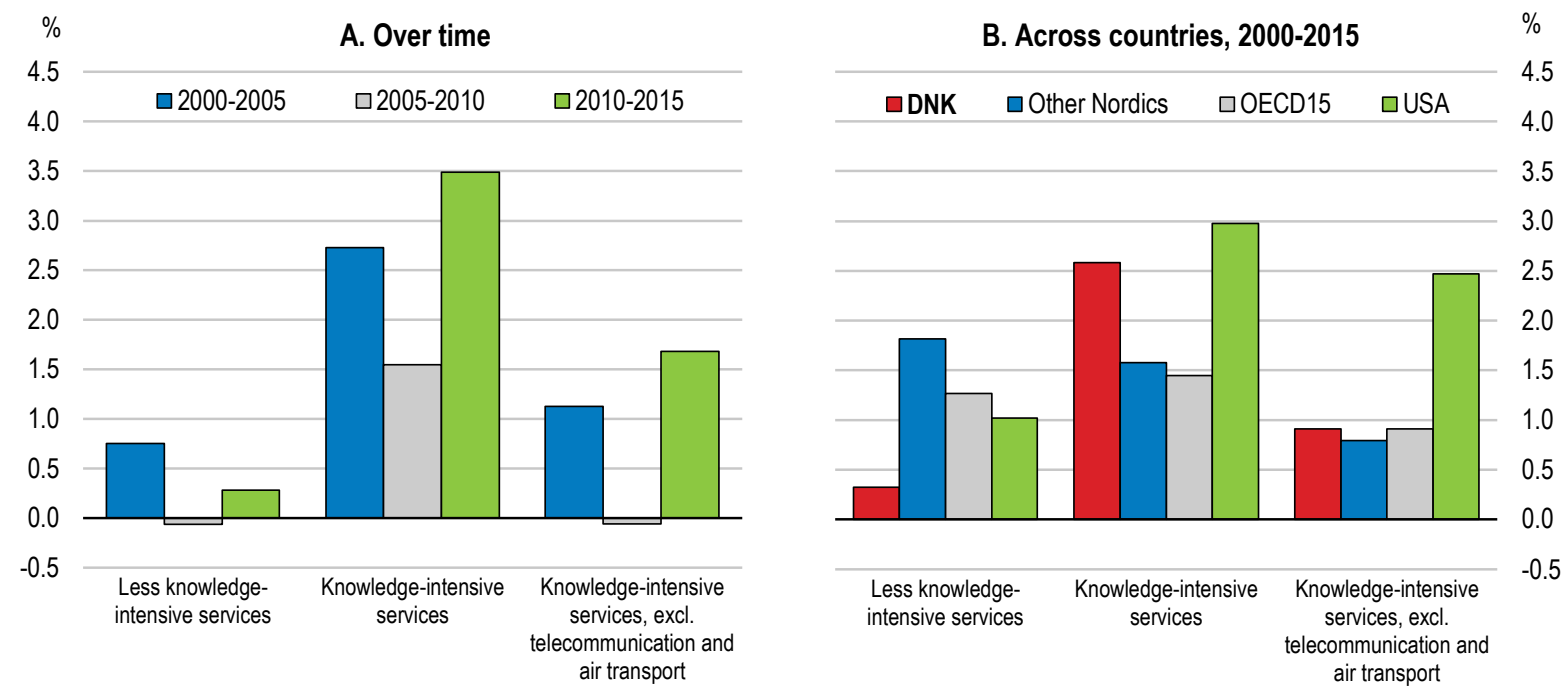

Note: Business sector services, excluding real estate, finance and insurance. Industry knowledge-intensity (at the 2-digit NACE level) is based on the Eurostat classification. Other Nordics is a simple average across Finland, Norway and Sweden; OECD15 is a simple average across 15 OECD countries with available data (Austria, Czech Republic, Denmark, Estonia, Finland, Greece, Ireland, Italy, the Netherlands, Norway, Slovak Republic, Slovenia, Spain, Sweden and the United States).

Source: OECD calculations based on OECD STAN database.

StatLink त्ञात् https://doi.org/10.1787/888933898919 
Box 2. How to group service industries to detect weaknesses?

Previous Surveys for Denmark (OECD, 2013 $[4]$; OECD, 2016 $[5]$ ) and the European Commission $\left(2018_{[6]}\right)$ have highlighted weak productivity growth in domestic-oriented services in contrast to internationalised services (defined as industries with a large export content or foreign-ownership share). This Survey applies a grouping by knowledgeintensity motivated by two reasons:

- First, major data revisions and the addition of more years modify earlier conclusions (Figure 6). Productivity growth has picked up in domestic-oriented services since 2010, whereas internationalised services have been on a downward trend since 2000 (Panel A), especially when excluding telecommunication and air transport. At the same time, the gap to other countries is mixed in both domestic-oriented and internationalised services (Panel B), suggesting no particular Danish productivity problem in either sector.

- Second, the substantial gap in growth rates between domestic-oriented and internationalised services is a less relevant comparison since reverse causality is likely as already pointed out by the Danish Productivity Commission $\left(2013_{[7]}\right)$. Internationalisation tends to increase competition and thus productivity growth, but industries with high productivity growth are also more competitive and thus more likely to operate in international markets. This can also be an issue for knowledge-intensity, but the extent of R\&D activity or share of high-skilled workers tend to be more closely related to the nature and output of the service industry than to productivity growth.

Figure 6. Productivity growth in internationalised services is showing weaknesses

Average annual growth labour productivity growth
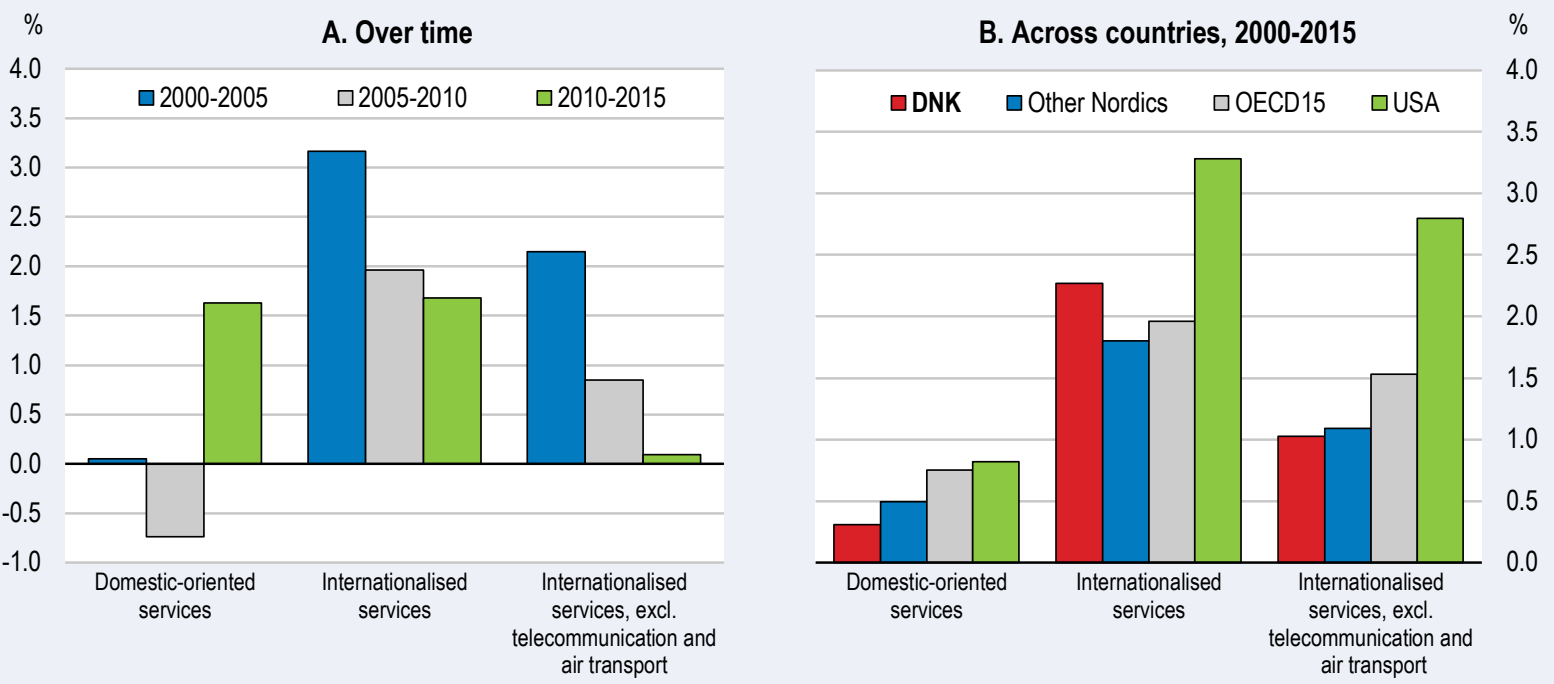

Note: See Table 1 for the grouping of services and Figure 5 for country coverage.

Source: OECD calculations based on OECD STAN database. 
Although internationalisation and knowledge-intensity have some overlaps, the two approaches are complementary as can be seen from the list of sectors (Table 1).

Table 1. Business services grouped by knowledge-intensity and internationalisation

Share of value added in business services for 2015 reported in each cell

\begin{tabular}{|c|c|c|}
\hline & Internationalised services & Domestic-oriented services \\
\hline $\begin{array}{l}\text { Knowledge- } \\
\text { intensive } \\
\text { services }\end{array}$ & $\begin{array}{l}\text { Water and air transport } \\
\text { Publishing activities } \\
\text { Audiovisual and broadcasting activities } \\
\text { Telecommunication } \\
\text { Computer programming, consultancy and } \\
\text { related activities } \\
\text { Security and investigation activities }\end{array}$ & $\begin{array}{l}\text { Information service activities } \\
\text { Legal and accounting activities } \\
\text { Activities of head offices, management consultancy } \\
\text { activities } \\
\text { Architectural and engineering activities } \\
\text { Scientific research and development } \\
\text { Advertising and market research } \\
\text { Other professional, scientific and technical activities } \\
\text { Veterinary activities } \\
\text { Employment activities }\end{array}$ \\
\hline & ( $18.7 \%$ of value added) & ( $20 \%$ of value added) \\
\hline $\begin{array}{l}\text { Less } \\
\text { knowledge- } \\
\text { intensive } \\
\text { services }\end{array}$ & $\begin{array}{l}\text { Wholesale trade } \\
\text { Postal and courier activities } \\
\text { Travel agency, tour operator reservation } \\
\text { service and related activities } \\
\text { Services to buildings and landscape activities }\end{array}$ & $\begin{array}{l}\text { Trade and repair of motor vehicles and motorcycles } \\
\text { Retail trade } \\
\text { Land transport } \\
\text { Warehousing and support activities for transportation } \\
\text { Accommodation and food services } \\
\text { Rental and leasing activities } \\
\text { Office administrative, office support and other business } \\
\text { support activities }\end{array}$ \\
\hline
\end{tabular}

Note: Classification by ISIC Rev. 4 of business services (45-82). Financial and insurance activities (64-66) and real estate activities (68) are excluded. Knowledge-intensity follows the definition by Eurostat. Internationalised services are defined by the Danish Productivity Commission (2013[7]) and compose industries with an export share of more than $25 \%$ and industries with foreign-ownership share above $25 \%$ in terms of value added.

\section{Weak growth in services even at the productivity frontier}

The global productivity slowdown has coincided with an apparent increasing performance gap between firms at the frontier and other firms at the global level (Andrews, Criscuolo and Gal, 2016 $[8]$; Berlingieri, Blanchenay and Criscuolo, 2017 $[9])$. A similar widening gap has been found within countries in Germany and Switzerland and to some extent in Belgium (OECD, 2018 ${ }_{[10]}$; OECD, 2017 $7_{[11]}$; OECD, 2017 $\left.{ }_{[12]}\right)$. Such a development has not been observed in Denmark (Kristoffersen, Spange and Malthe-Thagaard, 2017 $[13]$; Danish Economic Councils, 2017 $[14]$ ). The gap in labour productivity between firms at the frontier and other firms has not increased substantially both in manufacturing and in services (Figure 7). 
Figure 7. The gap to firms at the productivity frontier remains small in Denmark

Labour productivity, value added per worker

\section{A. Denmark}
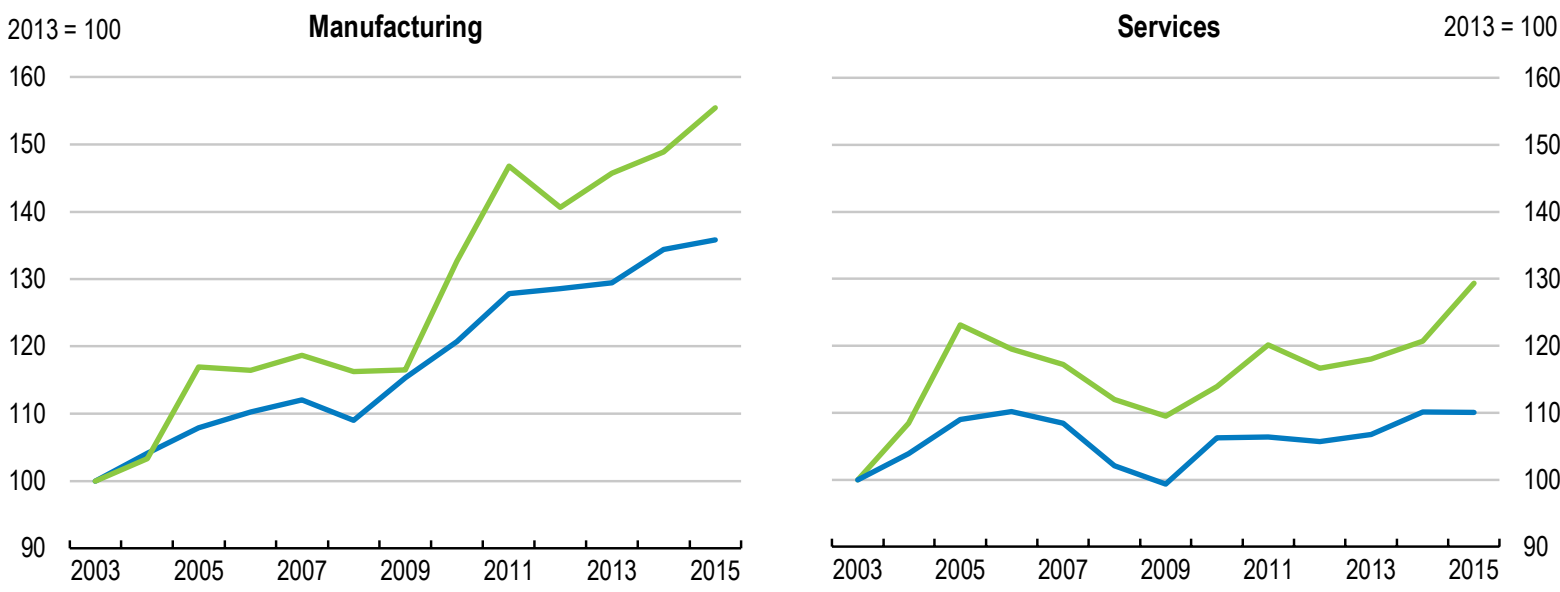

\section{B. OECD}
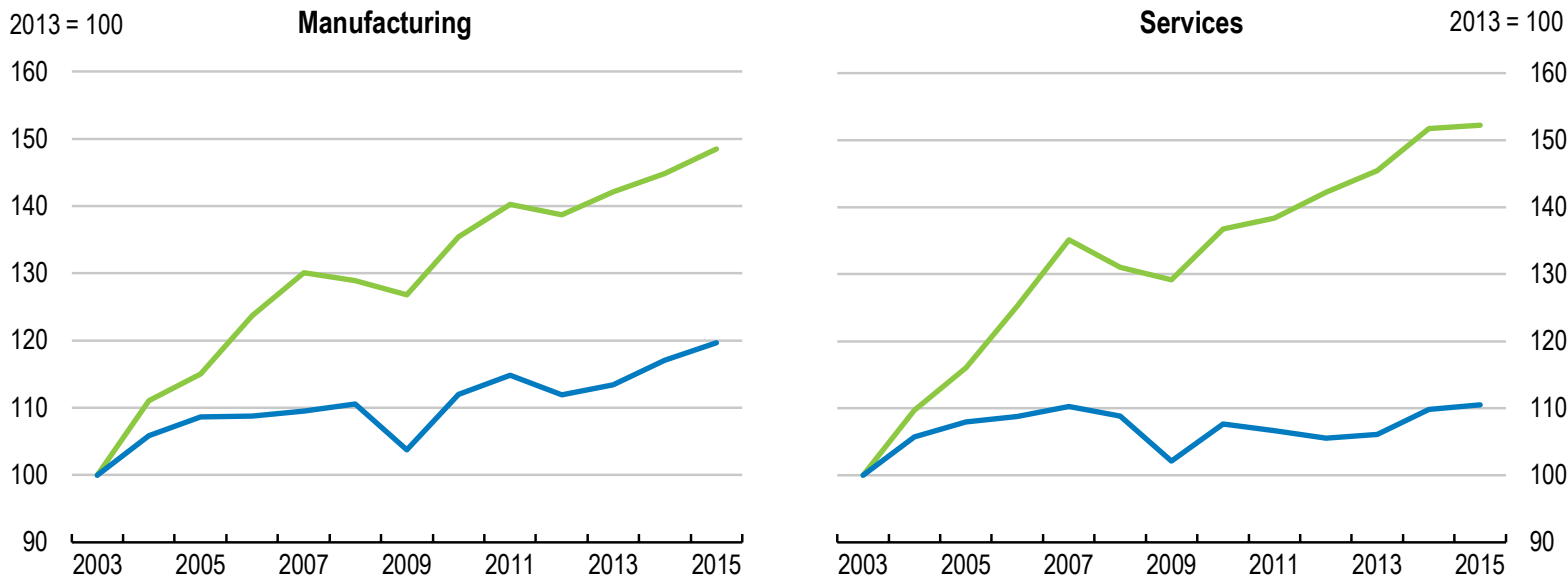

Note: In panel B, the "frontier" is measured by the average of log labour productivity for the top $5 \%$ of companies with the highest productivity levels globally across 24 countries, separately within each 2-digit industry and year. "Firms below the frontier" capture the log productivity for all other firms, constructed in a similar way. The series are normalised to 100 in the starting year $(2003=100)$ and the time variation is approximated by changes in the log measures $x$ 100. In panel A, a similar approach is applied for Danish firms only. OECD series are based on ORBIS data, while series for Denmark are based on national business register data. The comparison is suggestive since data sources and methodologies are not fully comparable (Panel A uses weighted averages across 2-digits industries, whereas unweighted averages are used in Panel B).

Source: Danish Economic Councils $\left(2017_{[14]}\right)$; OECD calculations using Orbis data of Bureau van Dijk, following the methodology in Andrews et al. (2016[8]).

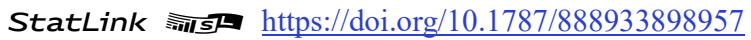

Comparing productivity trends within Denmark to global developments points to two main differences (Figure 7): firms below the frontier in manufacturing have largely kept up with the frontier, while no frontier has emerged in services as even firms at the top have 
experienced persistently slow productivity growth. In this respect, the micro-level perspective reinforces the challenges identified at the macro-level by pointing to strong and broad-based growth in manufacturing (albeit potentially distorted by integration in global value chains, see Key Policy Insights) and a worrying lack of innovation leaders to drive productivity growth in services (except for telecommunication and air transport), which will be increasingly critical as the economy transform further towards services.

\section{Key challenges for reviving productivity growth through new technologies}

Predicting future technological changes and their implications is impossible, but potential adverse shocks can be mitigated by being prepared. In this respect, the Government has launched a "Disruption Council" (Box 3) that brings together policy-makers, social partners and experts in Denmark to discuss how to seize opportunities of technological changes in the best possible way, so that all Danes take part in economic development.

\section{Box 3. The Danish Disruption Council}

In May 2017, the Danish Government established a "Disruption Council”, a partnership between the social partners, businesses, experts and the Government. The Prime Minister chairs the Council with 29 members and seven ministers participating. The mandate of the Council is to analyse, discuss and make recommendations on future challenges from technological changes and globalisation with two objectives (Danish Government, $\left.2017_{[15]}\right)$ :

1. Ensure a strong Denmark that seizes the opportunities of technological changes in the best possible way, so that all Danes take part in economic development.

2. Maintain and develop a labour market, which is dynamic and well organised and without social dumping.

The work is organised in a series of two-day meetings with presentations and discussions around five overarching topics:

- New technologies and business models

- Skills for the future

- Globalisation, free trade and foreign workers

- Framework conditions for businesses

- Flexicurity 4.0 - sustaining the Danish labour market model

Based on discussions and recommendations from the Council, the Government will launch a number of policy proposals and strategies. A final report reviewing the Government's initiatives is expected in the beginning of 2019 .

Maintaining an inclusive labour market is at the core of the Council's work. In this respect, this chapter is complementary by focusing more on the business sector and the need to adjust related policies in response to new technologies and business models. The following key challenges are identified in the rest of this chapter:

- Weak business dynamics in upscaling: Only few young firms are able to scale up their businesses and gain export market shares. This may point to various market failures, including strong market power by incumbents or lack of risk capital. 
- Slow investment: More investment should be expected given ultra-low borrowing costs and large corporate savings. The need for more market-based funding is rising as investment shifts towards intangibles and new business models emerge.

- Highly concentrated innovation: High aggregate R\&D spending conceals a strong concentration of business R\&D in a few large firms in a handful of sectors.

- Limited use of advanced digital technologies: Uptake and innovation in future key enabling technologies (e.g. artificial intelligence and the Internet of Things) is relatively low.

- Skill shortages: The share of graduates in science, technology, engineering and math is low compared to other countries, while businesses increasingly report shortages in these skills.

Addressing these challenges and preparing for disruption can go together and deliver synergies. Danish firms are close to the technological frontier compared to other countries, making disruptive innovation that raises the technology frontier key to boost productivity growth. Improving framework conditions to foster trials of new ideas and investment requires a multidimensional policy perspective to enable firms to exploit new opportunities. Most of all, policy needs to level the playing field by leaning against attempts to discourage disruptors or exclude them and by tackling unintended or outmoded obstacles in legislation and regulation. At the same time, policy needs to consider downsides for consumers and employees' welfare and to establish whether disruption marks a positive innovation, or for instance is founded on regulatory or tax loopholes.

Recent policy initiatives have further supported the already high level of digitalisation and embraced new business models and the collaborative economy (Box 4). A range of measures has also been taken to foster entrepreneurship and improve framework conditions for businesses. The Government developed many of the policy measures in collaboration with business CEOs and experts through the appointment of so-called growth panels (such as the Entrepreneurship Panel and the Digital Growth Panel), facilitating open discussion and knowledge sharing.

Most of the initiatives are welcome as they aim to remove barriers and adapt regulation with a technology-neutral focus. However, additional tax expenditures, such as tax deductions for investment in unlisted entrepreneurship SMEs, should be used with caution. 
Box 4. Recent policy initiatives to enhance digitalisation and the business environment

- Liberalised zoning and planning regulation (June 2016). Rules concerning shop size and location as well as placement of production eased. More decisionmaking power on zoning and planning regulation transferred to municipalities.

- Business and entrepreneurship reform package (November 2017). Introduction of a tax-favoured stock account, implying an additional lower tax bracket for income from dividends and realised capital gains. New tax deduction for households investing in unlisted entrepreneurship SMEs. Gradually increased tax deduction of R\&D expenditures from $100 \%$ to reach $110 \%$ in 2026 . Extension of favourable tax scheme for certain high-skilled foreign employees from five to seven years. Life science growth strategy to promote and offer qualitative support to businesses in pharmaceuticals. Total resources allocated to the package amounts to EUR 2 billion (0.7\% of GDP) during 2018-2025.

- Ensure legislation supports digitalisation (January 2018). Principles for simple and clear legislation to facilitate digitalisation adopted. New legislation to be assessed against them and ongoing revision to adjust existing legislation.

- Digital growth reform package (February 2018). Launch of a public-private partnership, Digital Hub Denmark, to strengthen growth and research in new digital technologies. Programme to support digitalisation of SMEs through guidance and knowledge sharing. A Technology Pact with businesses and the education sector to boost STEM skills and graduates, including more women. Measures to foster data-driven growth, among other development of a block chain solution for ship registration and free access to weather data. Initiatives to make business regulation technology-neutral and ready to support new business models.

- Strategy for cyber and information security 2018-2021 (May 2018). Measures and resources to strengthen surveillance, coordination and improve competences for secure communication and data protection.

- Growth and taxation of collaborative and platform economies (May 2018). Review of legislation and regulation to remove unintended barriers for collaborative activities. New and simpler tax deductions for income from accommodation and rental of cars, boats and caravans conditional on automatic reporting to tax authorities through a third party. Clarification of the rules for short-stay rentals, restricted to maximum 70 days per year.

- Simplification of business promotion services (May 2018). The Danish Growth Fund (Vcekstfonden) will be the one-stop for access to loan and equity to (knowledge-based) entrepreneurship, while subsidies for innovation and R\&D will be facilitated through the Innovation Fund. Access to supervision, guidance and mentoring will be provided through 12 local business centres with links to all municipalities as well as through a digital business promotion platform.

- Digital public service strategy (October 2018). Individual access to all personal data records by the public sector. Appointment of an advising Data Ethical Council. Digitalisation of identity documents. Investment fund (EUR 55 million) to boost development of new technologies and artificial intelligence. 
Additional reforms are needed to boost productivity and prosperity so that Denmark remains among the most successful OECD countries and champions in wellbeing. This chapter examines a broad set of policies to respond to the key challenges, centred on framework conditions and support of businesses when needed:

- Promoting competition and reducing regulatory barriers: Refining the competition framework and reforming regulation are needed to adapt to new business models and maintain high business dynamics.

- Rebalancing taxation and improving access to finance: Reducing top marginal tax rates on labour and capital income will improve economic incentives for labour supply and investment. Expanding the equity market requires corporate income tax reform and consideration of obstacles for pension funds to invest.

- Fostering broad-based knowledge creation and $R \& D$ support: Strengthening opportunities and incentives for more firms to engage in R\&D and become innovative will broaden knowledge creation and productivity growth.

- Enabling businesses to thrive in the digital age: Mainstreaming the use of advanced digital technologies, also in the public sector, and building trust in the new digital economy will accelerate digital transformation.

- Building skills and easing access to foreign workers: Ensuring supply of the right skills is crucial to utilise advanced technologies and boost productivity. Maintaining effective upskilling and lifelong learning will help workers cope with disruptive changes, while not least ensuring that economic growth benefits all.

\section{Refining competition and regulatory frameworks to promote business dynamics}

Recent waves of innovations in digital technologies may have contrasting effects on business dynamics. While digital technologies are likely to lower barriers to entry and facilitate reallocation, some features of digital-intensive sectors, such as economies of scale and scope and network effects, can also favour winner-takes-most dynamics and the emergence of dominant firms (e.g. related to big data, platforms, computer algorithms, intellectual property), increasing concentration and market power (OECD, 2018 ${ }_{[16]}$; OECD, $2017_{[17]}$; Bessen, 2017 $\left.[18]\right)$. More generally, there is evidence that the rise of intangibles is associated with a rise in concentration (Crouzet and Eberly, 2018 ${ }_{[19]}$ ). Competition and regulatory frameworks thus need to be refined to fit this new environment.

\section{Few young firms grow large, but business dynamics has remained high}

Business dynamics through entry and exit of firms is at a high level compared to other countries and has remained stable since the early 2000s (Figure 8), with the exception of cyclical movements around the financial crisis in 2008-2009. This provides a good foundation to support productivity growth via reallocation of resources from less to more productive firms. Indeed, over the last decades business dynamics has been the main source of (weak) productivity growth in services (Malchow-Møller, Munch and Skaksen, 2015 [20]; Danish Ministry of Finance, 2016[21]). 
Figure 8. Business dynamics has remained high compared to other countries

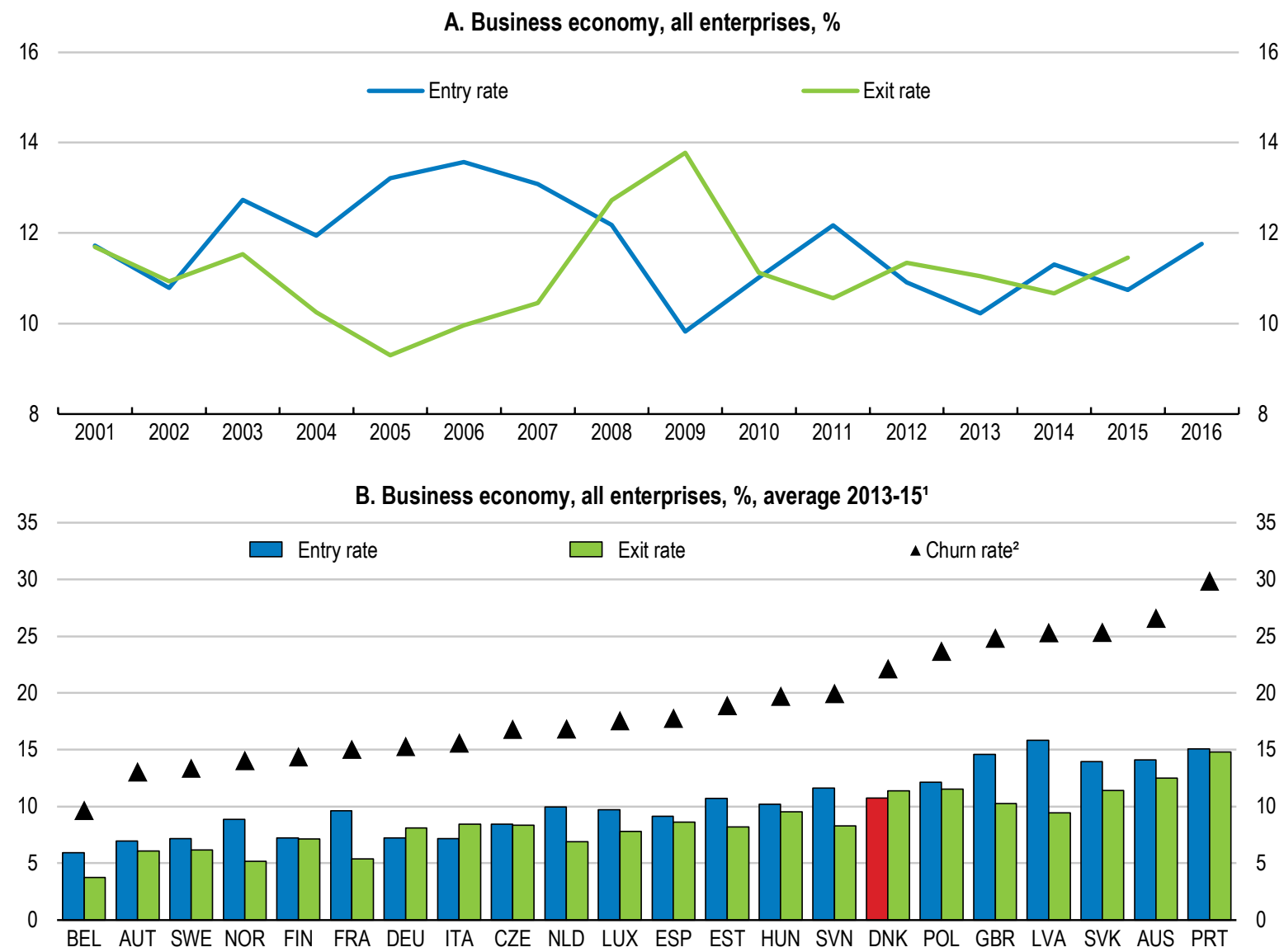

1. Data for Denmark and Poland refer to 2012-2014.

2. The churn rate is the number of enterprise births and deaths as a percentage of the number of active enterprises.

Source: Statistics Denmark; OECD Structural and Demographic Business Statistics.

StatLink त्ताs https://doi.org/10.1787/888933898976

Nevertheless, business dynamics display weaknesses with respect to survival and upscaling compared to other OECD countries. Young firms exit at a higher rate than in Sweden and the Netherlands (Figure 9, Panel A), while surviving young firms account for less than $10 \%$ of total business sector employment (Figure 9, Panel B), less than in most other OECD countries. On the one hand, this can point to a flourishing startup environment with plenty of experimentation and risk taking combined with effective procedures for firm closure (Adalet McGowan, Andrews and Millot, 2017 $7_{[22]}$. New technologies also facilitate "scale without mass", reducing the need to grow large to become productive in some service sectors (Berlingieri, Calligaris and Criscuolo, 2018 ${ }_{[23]}$ ). 
Figure 9. Many young firms exit and those remaining employ a low share of workers

\section{A. Survival rates, $\%$, average $2013-15$}

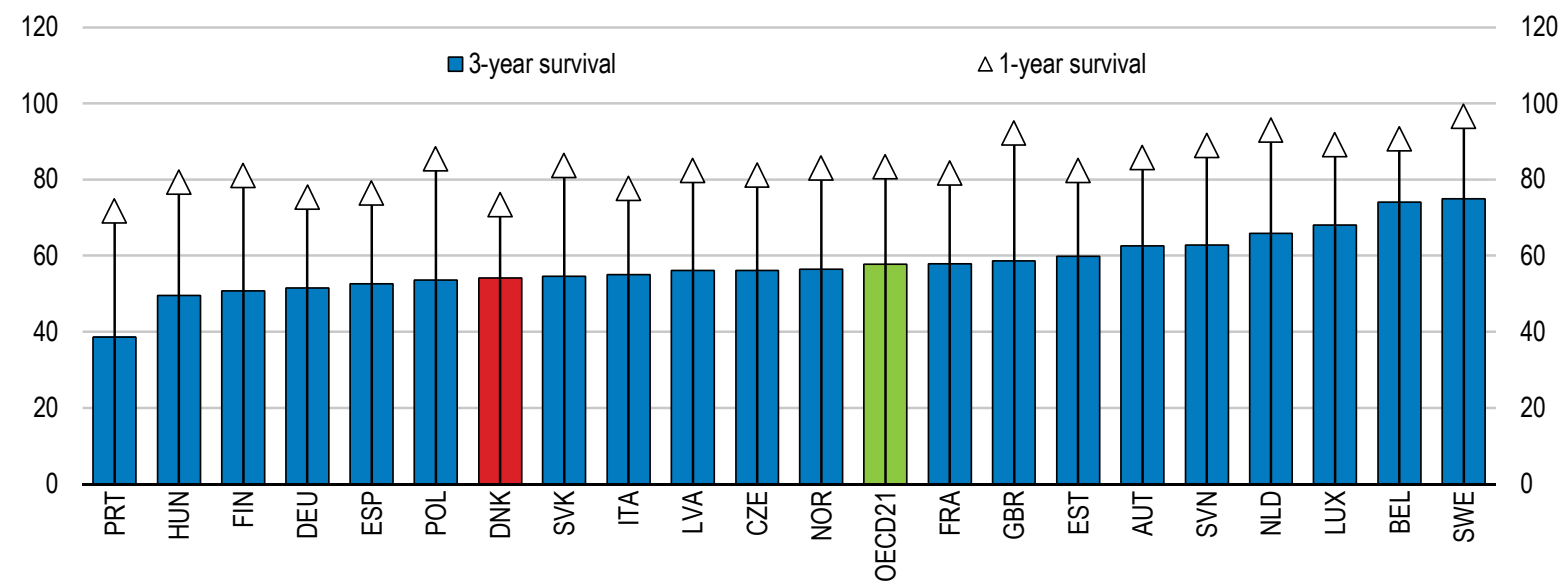

\section{B. Employment share, \%, average 2013-15}

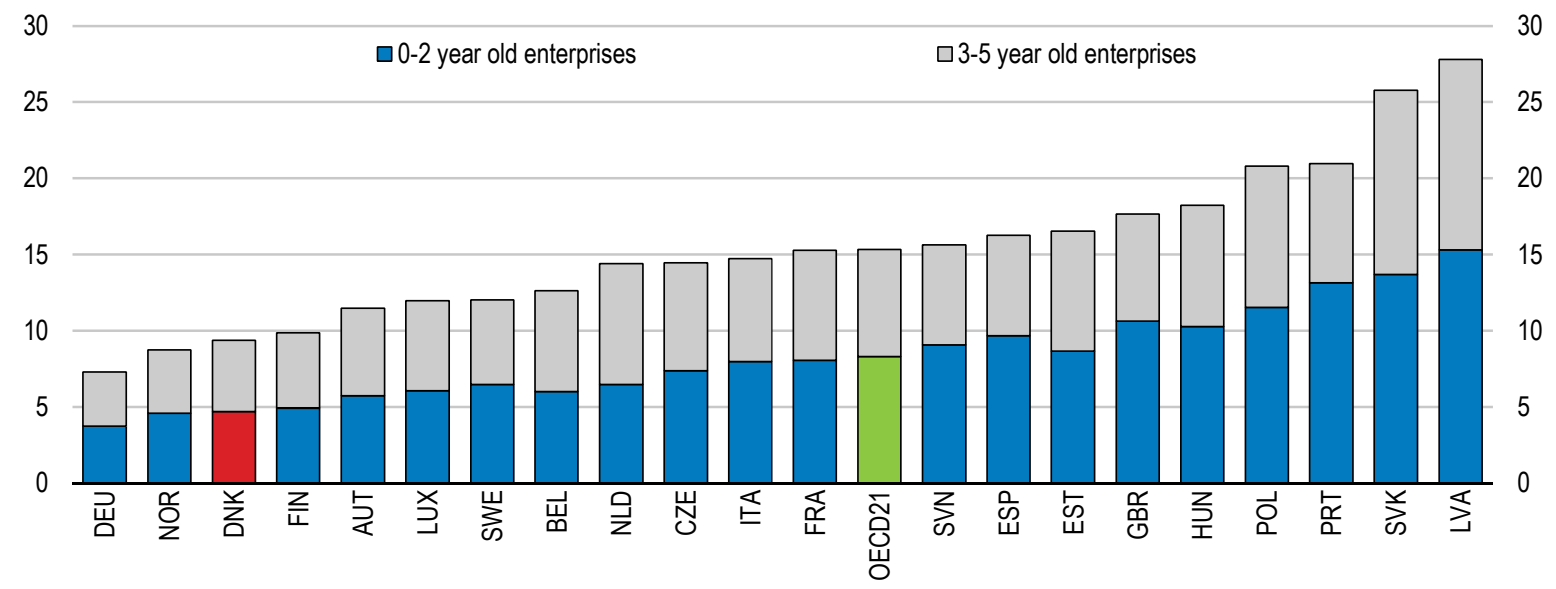

Note: Business economy, all enterprises. Data for Denmark refer to 2012-2014.

Source: OECD Structural and Demographic Business Statistics.

\section{StatLink त्गाड़ https://doi.org/10.1787/888933898995}

On the other hand, a low employment share in young firms can indicate barriers to growth such as lack of skilled workers and weak competition, protecting incumbent firms (Calvino, Criscuolo and Menon, 2016 [24] $)$. The technological transformation implies that many new firms are now created in knowledge-based services (i.e. professional, scientific and technical activities) and the ICT sector (Figure 10). If supply of high-skilled workers is insufficient or regulatory barriers excessive, successful startups will be more encouraged to move their businesses abroad; a concern that has been emphasised by the Danish Entrepreneurship Panel $\left(2017_{[25]}\right)$. Market size can also be a constraint as ICT startups typically aim for a global market and can be constrained by lack of integration in the EU digital market. 
Figure 10. The composition of new firms has shifted towards knowledge-based and ICT services

New firms by industry, business sector only

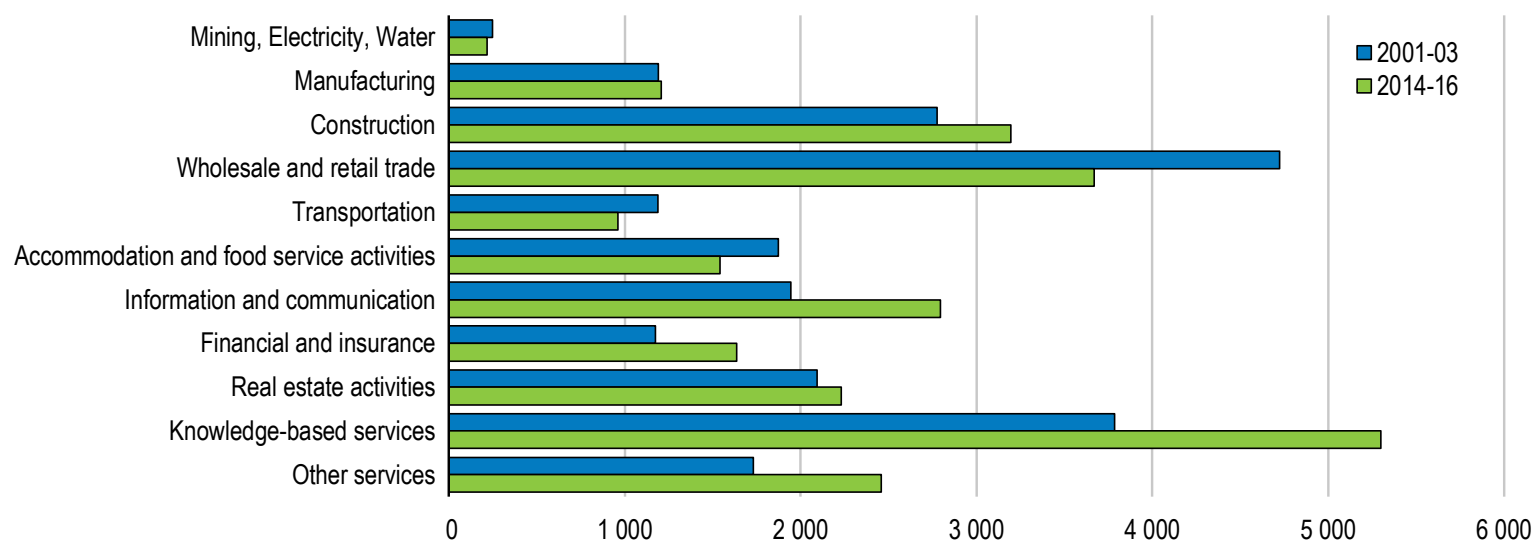

Source: Statistics Denmark.

\section{Promoting competition and reducing regulatory barriers}

The low number of startups scaling up in Denmark may be seen as a result of low competition pressure and of the rising market power of a few dominant firms. Competitive pressure can be assessed by computing mark-ups, i.e. the ratio of unit price over marginal cost. This ratio is higher than one when markets are not perfectly competitive for example due to product differentiation or barriers to entry. Other factors can also contribute to high mark-ups, such as large fixed costs or a high degree of innovation (Calligaris, Criscuolo and Marcolin, 2018 $\left.{ }_{[26]}\right)$.

Mark-ups have been stable on average over the past decades, but have displayed different patterns across sectors (Figure 11). In sectors like retail trade, where global competition and more recently online competition have put a downward pressure on prices, mark-ups have been steadily decreasing. The reverse pattern is observed in sectors relying heavily on intellectual property products, such as pharmaceuticals, or more recently in ICT services. The latter is consistent with patterns observed in other countries, where services and especially digital-intensive sectors have seen an important rise in mark-ups over time (Calligaris, Criscuolo and Marcolin, 2018[26]), which is consistent with winner-takes-most dynamics. While these effects so far remain limited in Denmark, they are likely to gain importance in the future to the extent that the digital economy will grow and disrupt additional sectors of the traditional economy. 
Figure 11. Mark-ups are stable on average, but on the rise in certain sectors

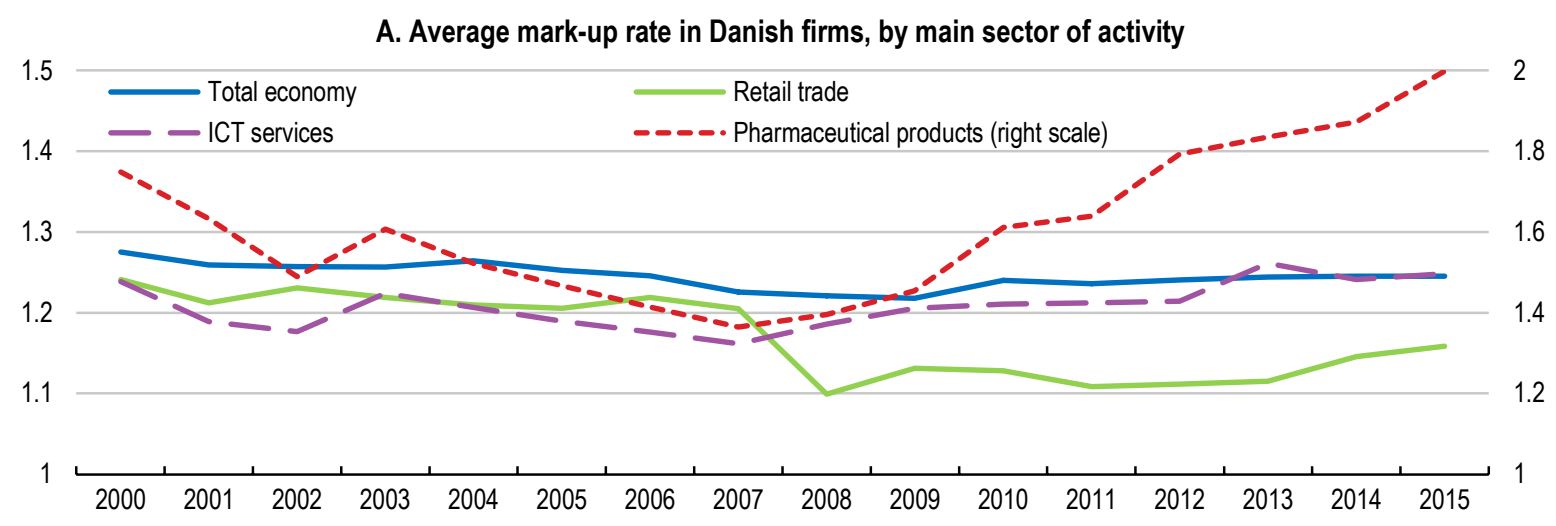

B. Average mark-up rate, by country, 2015

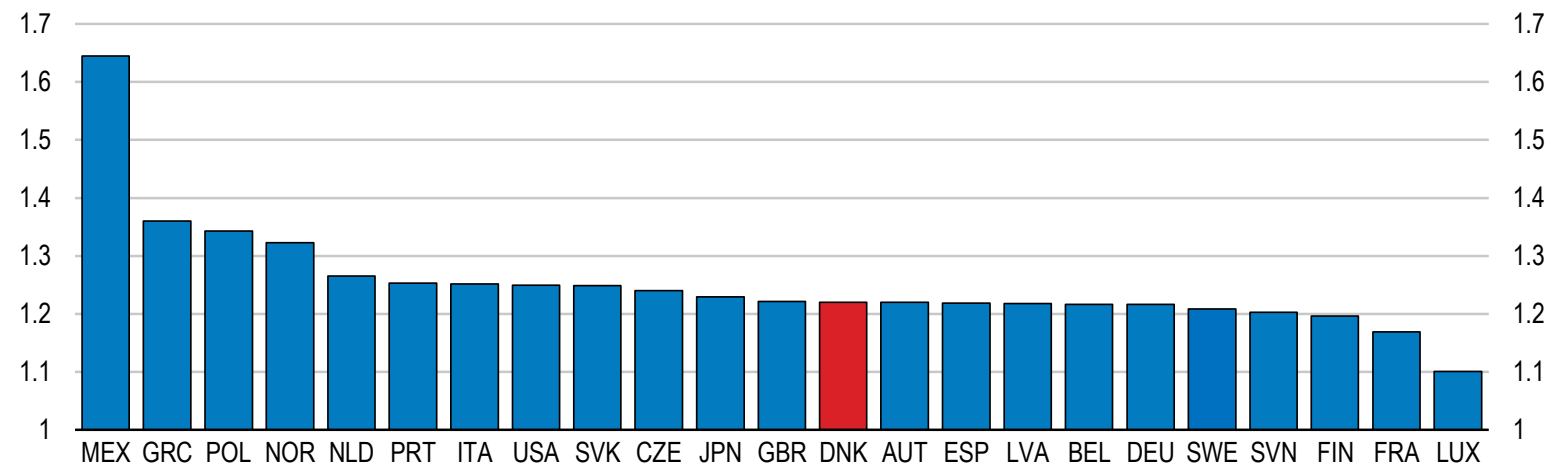

Note: Mark-up rates are calculated at the industry level as the ratio between operating surplus and input costs. Input costs correspond to the sum of intermediate inputs and labour costs. This indicator takes a value above one if the mark-up is positive. In Panel B, figures for Sweden and the United Kingdom are for 2014.

Source: Égert and Vindics (2018[27]).

StatLink त्राज् https://doi.org/10.1787/888933899033

General competition law provides the main instrument to combat anti-competitive practices aimed at shutting out disruptors. The Danish competition framework is generally in line with international recognised standards and practices, but the structure for competition enforcement and determinations is considerably different and more complex than in most EU countries $\left(\mathrm{OECD}, 2015_{[28]}\right)$. Denmark is one of a small number of EU countries that make imposition of fines criminal penalties, which must be imposed by the courts. Moreover, the burden of proof is higher than in many other countries and court procedures tend to be complex and lengthy. While this unusual practice derives from Danish legal tradition, the high standards nevertheless involve the risk of weak deterrence if firms view the likelihood of prosecution and ruling as low. Consideration should be given to streamline the institutional setup to make determinations of anticompetitive practices more effective. Competition authorities should be provided greater authority to impose administrative fines and to use structural remedies (such as divesture of assets) (OECD, 2015 ${ }_{[28]}$ ).

The Danish Competition Act is also unusual in having a specific provision that permits individual Ministers (and local authorities) to make exemptions where anticompetitive 
practice is assessed to be "a direct or necessary consequence of public regulation". The clause is utilised on a regular basis $\left(\right.$ OECD , 2015 $\left.5_{[28]}\right)$ and means that within a number of sectors, exemptions from the general competition law are applied and industry-specific regulation is used (such as for pharmacies and the taxi industry). Societal concerns can justify such exemptions, but clearer standards for identifying activities that should be subject to exemptions should be developed to reduce the risk of unfair high prices for consumers. For instance, the competition authorities could be assigned a greater role and authority in the determination of exemptions.

Specific adjustments of competition policy in the context of the digital economy will also become necessary as stressed in the Government's recent Digital Growth reform package (Box 4). Those challenges are common in OECD countries and recent OECD work suggests that most countries will have to: i) broaden the focus of competition policy beyond goods, services and revenues to also consider data as the most vital competitive asset in some markets (e.g. digital businesses that offer "free" services in exchange for customer data); ii) adjust the way relevant markets and market power are defined (e.g. to integrate the case of many online platform markets where products are free and markets are twosided); iii) adapt competition policy tools to prevent companies from using algorithms for collusion; and iv) have a greater focus on international co-operation and co-ordination among competition authorities, as more and more businesses are born global and operate across jurisdictions (OECD, 2017 ${ }_{[29]}$; OECD, 2016 [30]; OECD, 2017 [31]).

\section{Promoting competition and flexible markets through the regulatory framework}

Denmark's regulatory framework is currently one of the most favourable to competitive markets (Figure 2), with low restrictions in product market regulation as well as service trade. Since 2015 the Government has assumed a stop on new regulation that introduces additional burdens for businesses (Danish Government, 2018 ${ }_{[32]}$ ), except for compelling reasons. It has also eased existing burdens for businesses by approximately EUR 0.2 billion during 2015-2018. Still, the number of regulated professions is higher than in some neighbouring countries (158 in Denmark versus e.g. 98 in Sweden and 132 in the Netherlands) (European Commission, 2018 [33]). Moreover, some of the current regulations may not be appropriate for the digital economy (if for example they have been introduced due to market failures resulting from information asymmetry that are now reduced due to digitalisation) and unduly hinder the development of new products and services. The novelty of the digital economy may face a regulatory "vacuum", and the uncertainty created by the absence of regulation may discourage innovation (OECD, 2018[34]).

The government is currently revising regulations in various areas (e.g. finance, real estate and consumer protection), following a framework and principle-based approach to achieve technology-neutrality, which is a welcome initiative for competition as well. Continued monitoring of the development of market failures and need for revised regulation in fastevolving sectors would moreover need to be strengthened, as such reviews currently take place on an ad hoc basis.

Emergence of new business models of the digital economy, such as online platforms relying on non-standard work, require adjustments in specific sectors. To date, challenges to taxi services by ride-share companies such as Uber have been among the most prominent internet-platform based disruptions. In January 2018, a revision of the regulatory framework of taxi services - which applies to all businesses operating in the taxi market, including through ride-sharing platforms - entered into force. It simplifies the license system with a plan to abolish restrictions on the number of licenses by 2020 , but maintains 
some restrictions on technical requirements (e.g. taximeter and seat sensors) and a price cap on taxi fares in order to protect consumers (OECD, 2018 $\left.{ }_{[35]}\right)$. These restrictions, as well as the three-year transition period regarding the number of licenses, are likely to discourage ride-sharing platforms from operating in Denmark and creates barriers to entry for new players and new business models. Further deregulation and liberalisation would be welcome in the taxi market to provide consumers the benefits from new services.

\section{Upgrading capital markets and rebalancing taxation to boost investment}

\section{Investment is shifting towards intangibles}

Total business investment as a share of GDP is gradually rising, but remains below the precrisis level (Figure 12, Panel A). The slowdown in investment has been broadly consistent with the changes in output according to recent analysis (Danish Economic Councils, 2016[36]; European Commission, 2017 $7_{[37]}$, although one study finds evidence of a temporary shortfall (IMF, 2018 [38]).

Figure 12. Business investments are picking up and shifting towards intangibles
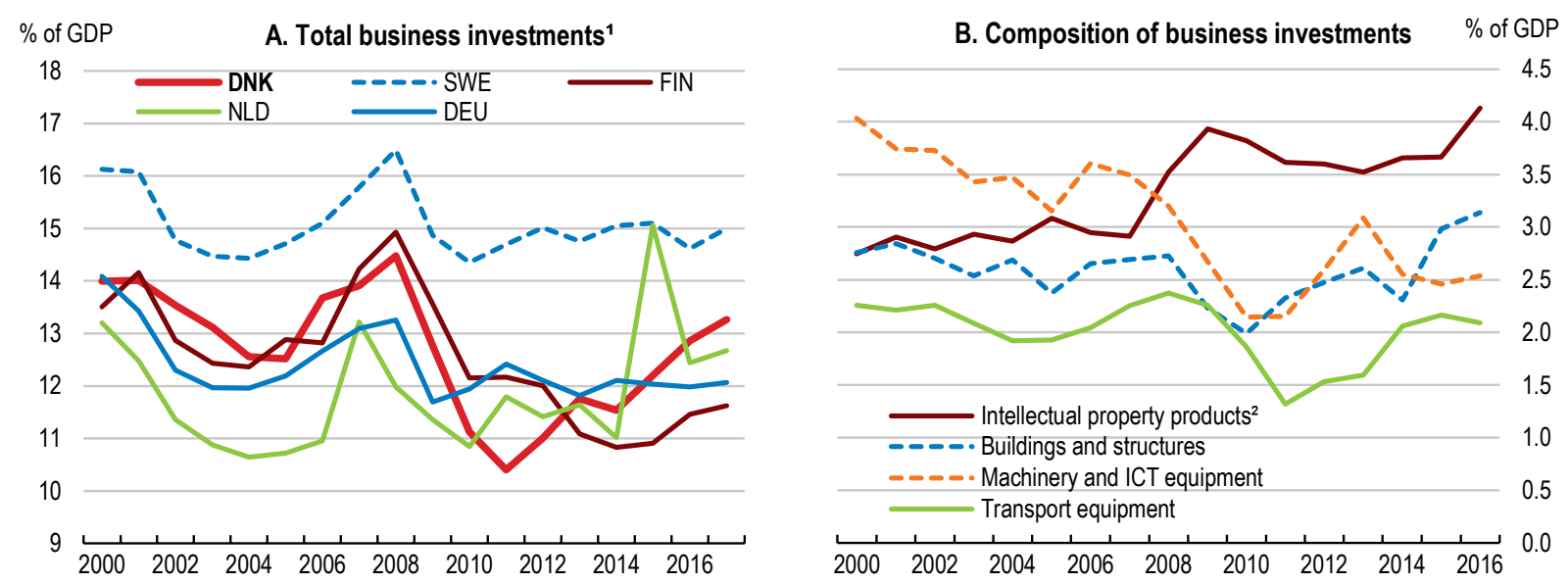

1. Private investment excluding residential buildings.

2. Intellectual property products include $\mathrm{R} \& \mathrm{D}$, computer software and databases; mineral exploration and evaluation; and entertainment, literary or artistic originals and other intellectual property products.

Source: OECD Economic Outlook database; Statistics Denmark.

StatLink त्गाजמ https://doi.org/10.1787/888933899052

Nevertheless, stronger investment in recent years could have been expected given ultralow borrowing costs. Non-financial corporations continue to accumulate low-yielding financial assets even though aggregate measures show that a wide gap has opened between the rate of return on non-financial assets and borrowing costs (Figure 13). High corporate savings may point to obstacles or lack of profitable projects, holding back firms from investing. Most firms report lack of skilled labour and uncertainty about the future as main impediments to invest (European Investment Bank, 2017 [39]). 
Figure 13. Corporations are accumulating financial assets despite a wide gap between return and cost of capital

Non-financial corporations
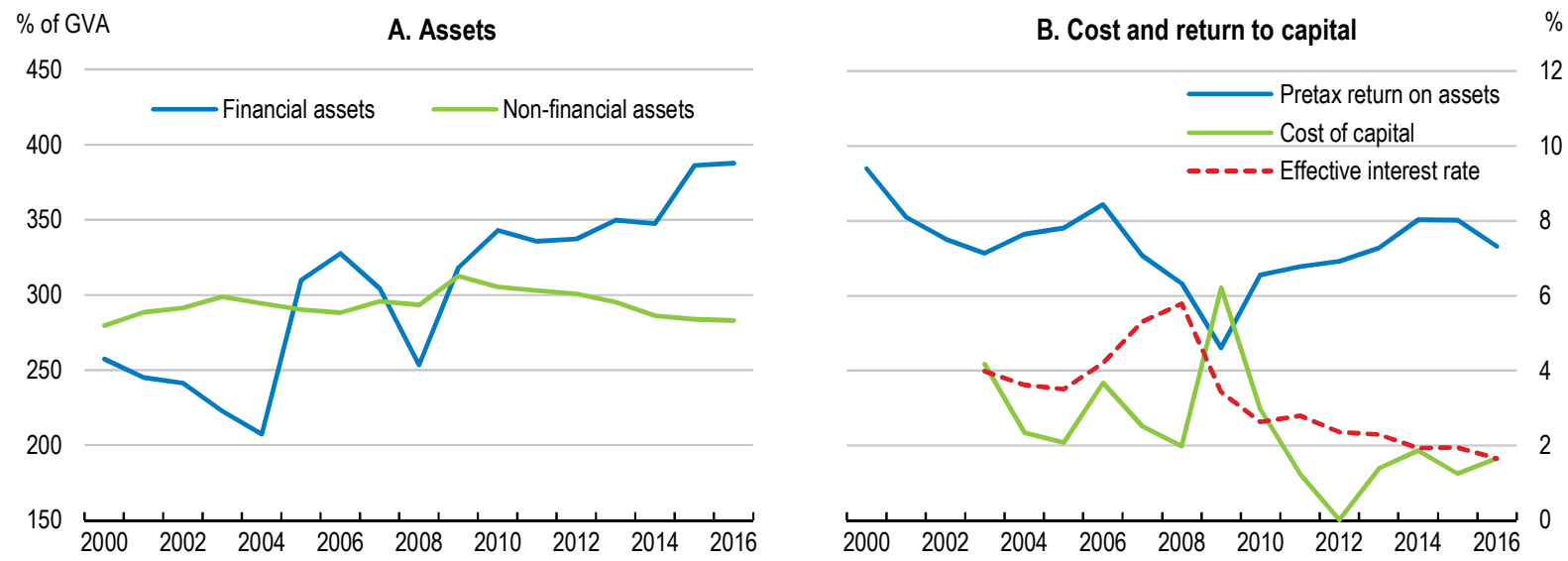

Note: Pre-tax return on assets is calculated as net operating surplus to non-financial assets. Effective interest rate for businesses is a weighted average of interest rates on new bank loans and new mortgage loans to nonfinancial corporations (average across all sizes, maturities and currencies). Cost of capital is effective interest rate minus the percentage change in the price deflator for non-residential fixed investment. A large increase in the deflator in 2012 temporarily drives cost of capital to zero.

Source: Statistics Denmark; OECD Economic Outlook database.

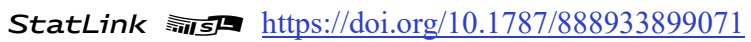

At the same time, intellectual property products (intangibles, including R\&D spending) has become the largest component of business investment, comprising about 35\% (Figure 12, Panel B). Yet, this is a national accounts measure of intangibles and only records a subset of total intangibles. Adding spending on e.g. training of workers, market research and organisational capital could double investment in business sector intangible assets (OECD, $2017_{[40]}$ ). The growing importance of intangibles implies that the association between investment and output may have become weaker over time due to the specific nature of intangibles (Thum-Thysen et al., 2017 ${ }_{[41]}$ ). In addition, the returns to knowledge-creating investment typically go well beyond the firm level and add to aggregate productivityraising innovation.

New analysis for this Survey based on Danish firm-level data suggests that digital adoption through investment in ICT increases firm productivity and contributes to business dynamics and firm growth (Box 5). However, ICT capital-deepening was close to zero over the period 2006-2015 for the aggregate business sector, while both tangible and intangible capital-deepening stalled in services (Danish Economic Councils, 2017 [14] $)$. As such, policy should focus on further unlocking ICT and intangible investment. In particular, since the evidence indicates that ICT capital boosts productivity in both knowledge and less knowledge-intensive services. 


\section{Box 5. ICT investment benefits business dynamics and firm productivity in Denmark}

Smeets and Warzynski $\left(2018_{[42]}\right)$ use rich Danish microdata to investigate the link between ICT investments, business dynamics and firm performance over the period 2000-2015. A novelty of the analysis is a distinction between the components of ICT investment (hardware, software and communication equipment) at the firm level.

\section{Industry-level analysis}

Firm entry and exit rates are computed by industry using register-based data of all Danish firms, while information about industry level components of ICT capital and investment is obtained from EU KLEMS. Panel data analyses indicate that higher shares of software and databases as well as communication equipment in total capital at the sectoral level is associated with a more dynamic environment (higher rates of firm creation and destruction) (Figure 14, Panel A).

\section{Firm-level analysis}

At the firm level, hardware and software spending are found to be positively related to employment growth. Structural analysis is used to estimate firm total factor productivity taking into account the endogeneity of ICT investment. Subsequently, all three ICT components are found to be positively associated with firm productivity (Figure 14, Panel B). A split by sectors indicates that this holds for both manufacturing and services.

\section{Figure 14. ICT investment is associated with higher business dynamics and higher TFP}
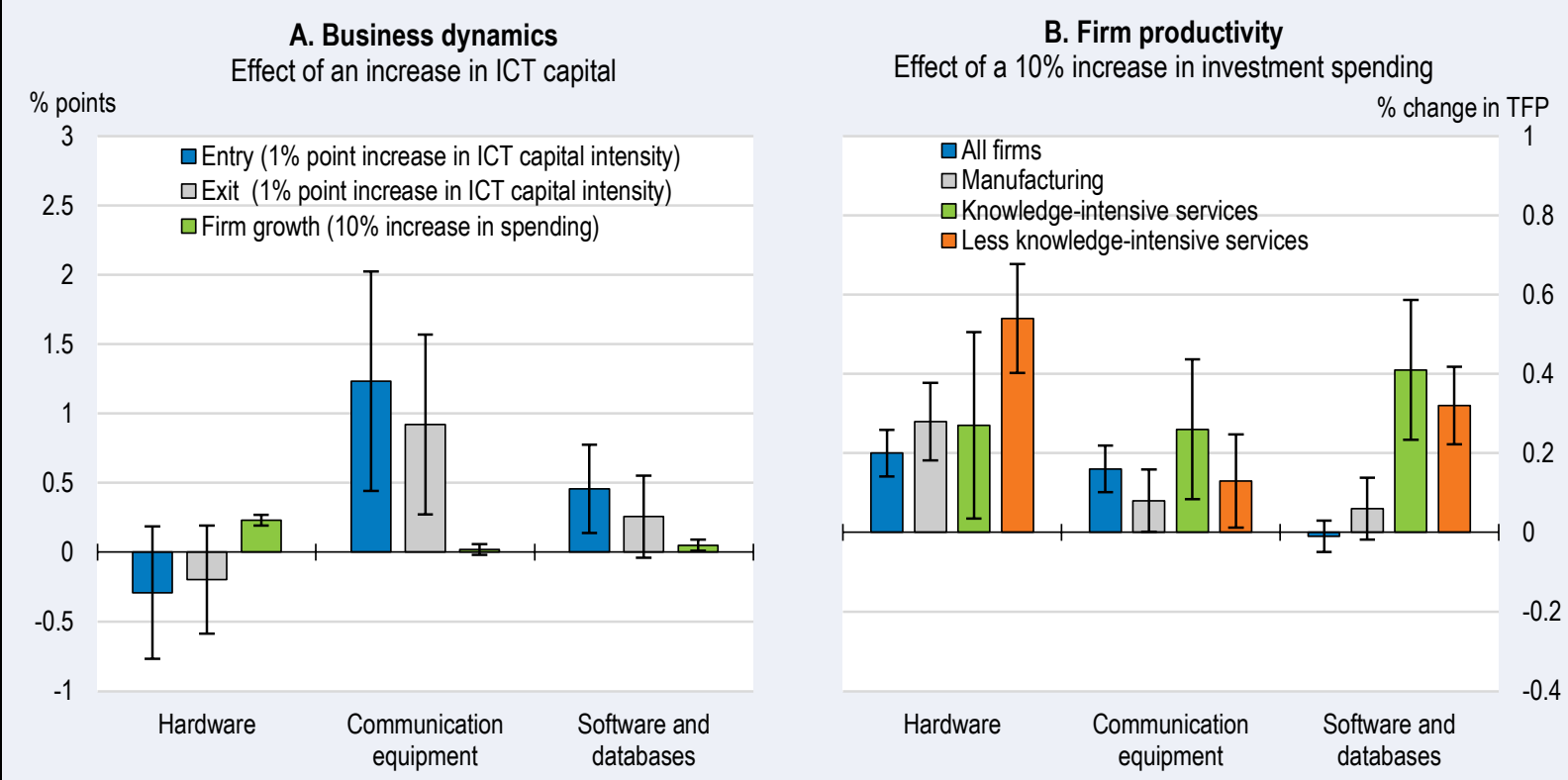

Note: The bars show point estimates and lines report confidence bands at the $5 \%$ significance level. Effects on entry and exit rates include controls for number of firms, capital per worker, year and industry fixed effects. Effects on firm growth and firm productivity use lagged ICT spending and controls for employment, capital per worker, year and industry fixed effects. See source for details.

Source: Smeets and Warzynski (2018[42]). 


\section{Upgrading firm financing to the knowledge economy}

Investment in intangible assets is often constrained by lack of external finance (Arquié, Demmou and Stefanescu, 2018 ${ }_{[43]}$ ). While patenting and licensing provide some means for collateralising, most intangibles, such as firm-specific human capital, cannot be used as collateral. In addition, intangible investments are typically riskier and the valuation more volatile, among others since they tend to be harder to transfer between firms. Ensuring that the financial system is able to channel finance to these kinds of investments is hence critical to accelerate productivity growth and the development of new business models (Thompson and Boschmans, 2018 [44] $)$.

On the surface, capital markets are well developed in Denmark (Figure 15). Stock market capitalisation is among the highest in OECD countries relative to GDP, while the corporate bond market has grown in size and is close to the euro area average. However, this masks the dominance of a limited number of very large firms and the bulk of Danish corporate bonds being issued abroad in foreign currency (Danish Ministry of Business and Growth, 2012 [45]; Danmarks Nationalbank, 2016 [46]). The equity market for smaller firms and the number of initial public offerings tend to be substantially smaller than in Sweden and other neighbouring countries (Copenhagen Economics, 2018 ${ }_{[47]}$ ).

While the aggregate debt-to-equity ratio is lower than in most OECD countries (Figure 16, Panel A), debt - mortgage loans in particular - are critical financing sources for the majority of firms (Figure 16, Panel B). Firms with real estate have increasingly used the well-functioning mortgage market to obtain inexpensive financing as rising capital requirements have tended to raise the cost of bank credit. In this context, better access to risky capital would help small and young firms develop or implement innovative technologies as such firms are usually confronted with higher interest rates and credit rationing.

Figure 15. Capital markets are well developed

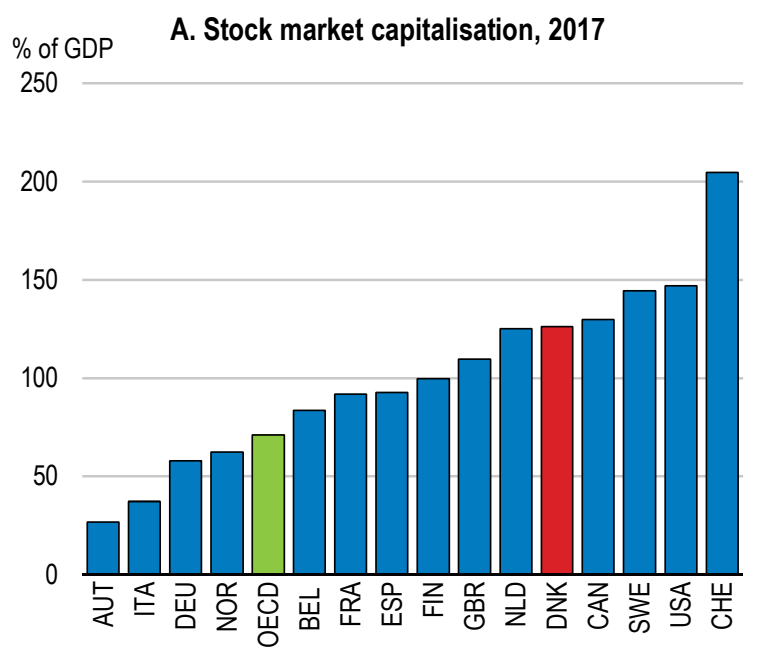

B. Corporate bond market, 2017

$\%$ of GDP

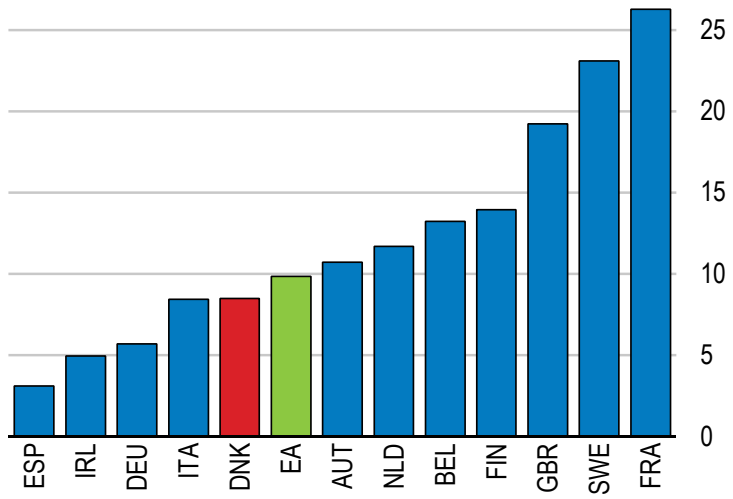

Note: Market value of outstanding shares listed on Copenhagen Stock Exchange in December 2017 (Panel A). Securities other than shares issued by non-financial corporations (Panel B).

Source: CEIC; European Central Bank. 
Figure 16. Debt-to-equity is low and dominated by mortgage loans
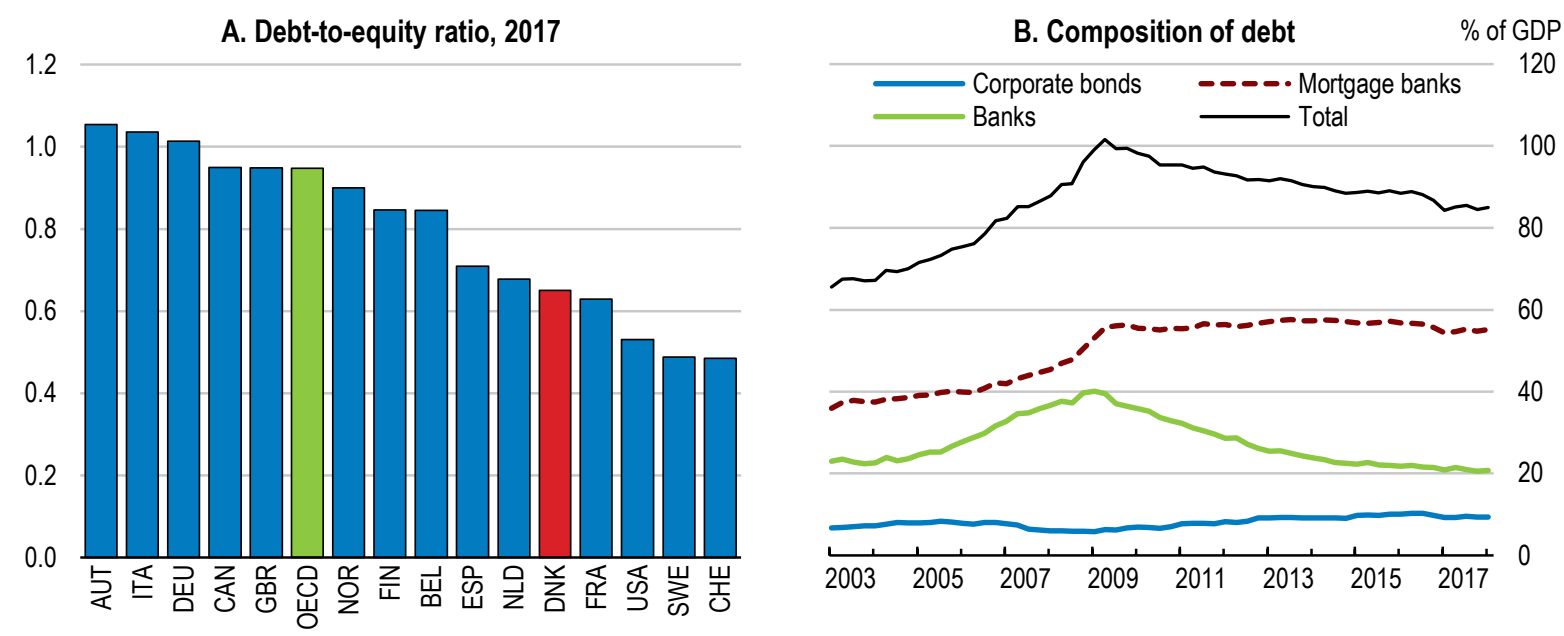

Source: OECD Financial Dashboard; Danmarks Nationalbank; Statistics Denmark.

StatLink הints https://doi.org/10.1787/888933899128

Financial markets in Denmark have seen some disruption as Fintech is evolving rapidly with a hub for Fintech entrepreneurs emerging in Copenhagen. Despite that, crowdfunding and peer-to-peer (or peer-to-market) lending occupy a small share of the market so far as in other countries (Havrylchyk, 2018 $8_{[48]}$ ). Given uncertainties in how best to regulate new financial services, authorities have taken an open approach by developing a regulatory "sand box", similar to initiatives introduced in the United Kingdom and Australia. This allows businesses that fit certain criteria to validate their concepts, while supervisory authorities benefit from new insights.

In contrast, the venture capital market is sizeable in Denmark as only Luxembourg raises more venture capital relative to GDP in Europe (Figure 17, Panel A). However, the bulk of these funds are invested abroad, predominantly reflecting a few Danish pharmaceutical

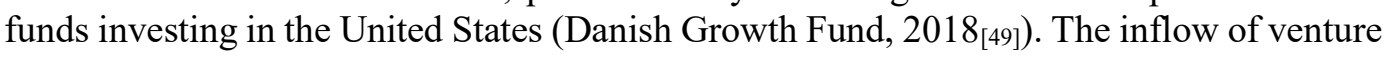
capital is much smaller, implying that venture capital investments in Danish businesses are close to the EU average and rank below Finland and Sweden (Figure 17, Panel B).

More worryingly, the market for growth capital is among the smallest across EU countries (Figure 18). Growth capital covers private equity investments (often minority investments) in relatively mature companies that are looking for primary capital to expand and improve operations or enter new markets to accelerate the growth of the business (Invest Europe, $\left.2018_{[50]}\right)$. A weak equity market for firms at this stage in their development is a likely contributing factor for young firms growing slower and upscaling less frequently than in other countries. 
Figure 17. Denmark raises plenty of venture capital but the majority is invested abroad
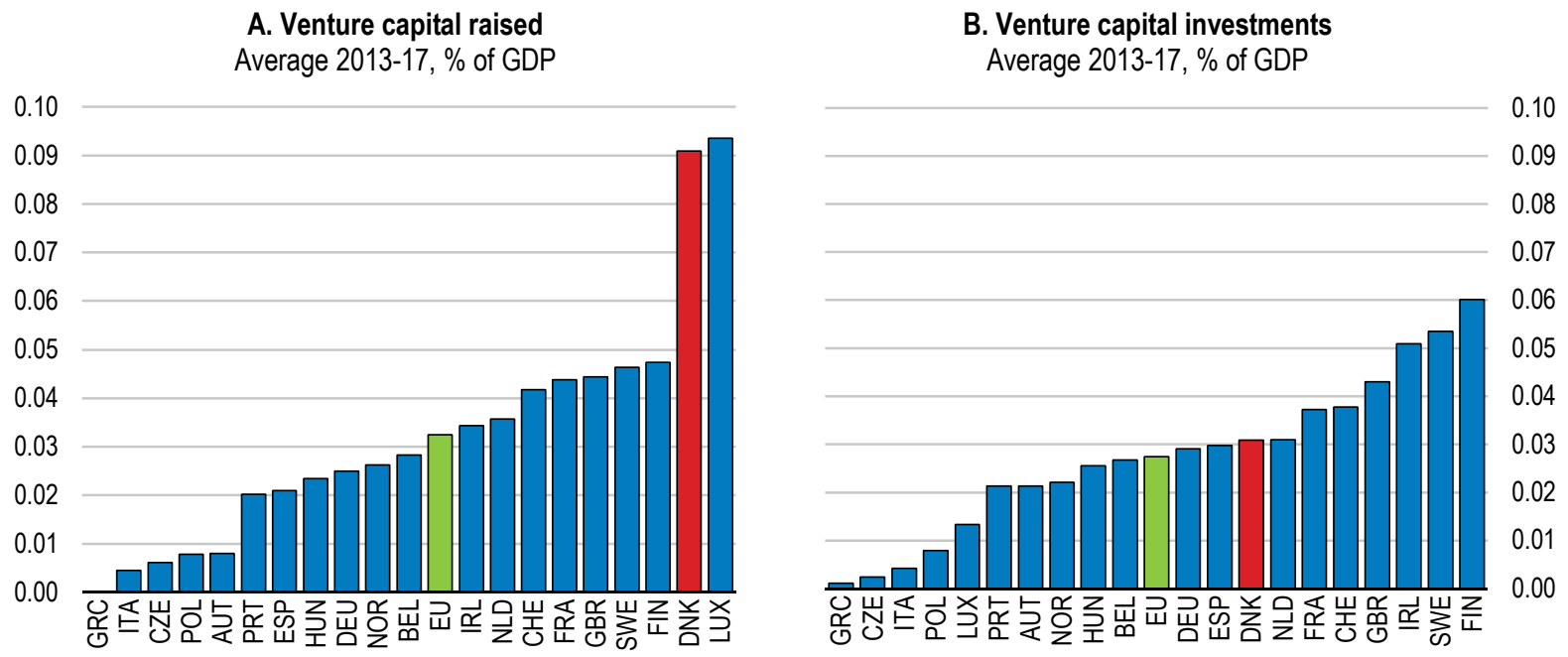

Note: Panel A records venture capital according to the location of the managing office and includes both domestic and foreign investments (industry statistics). Panel B records venture capital according to the location of the firms in the portfolio (market statistics) financed either by domestic or foreign venture capital funds. Source: Invest Europe, European Private Equity Activity Data 2017.

StatLink त्राज़ https://doi.org/10.1787/888933899147

Figure 18. Growth capital for businesses to expand is scarce
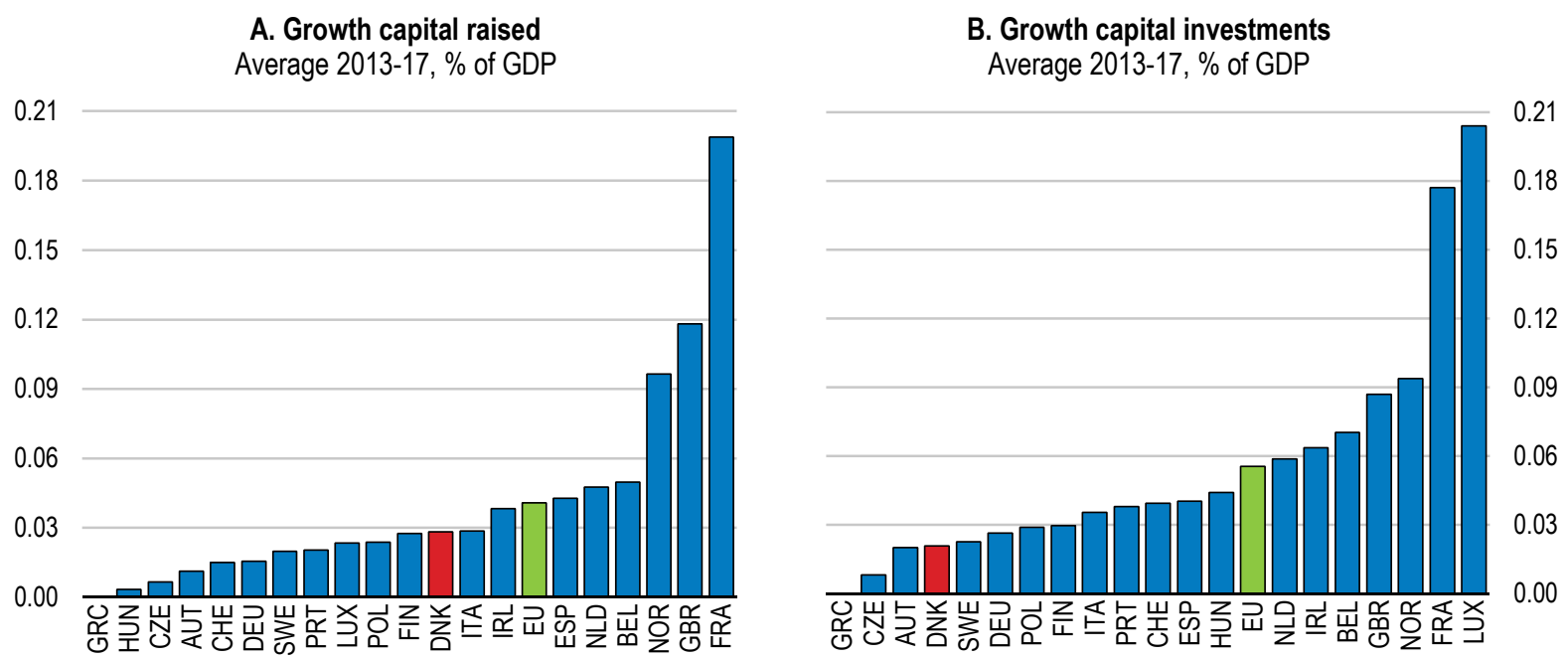

Note: Panel A records growth capital according to the location of the managing office and includes both domestic and foreign investments (industry statistics). Panel B records growth capital according to the location of the firms in the portfolio (market statistics) financed either by domestic or foreign growth capital funds. Source: Invest Europe, European Private Equity Activity Data 2017. 
Public business promotion services can address possible market failures by providing risky capital to firms with no other financing options, including through funds-of-funds support. As in most OECD countries, support schemes in Denmark are strongly focused on entrepreneurship and early-stage support to commercialise innovations (OECD, 2018 [51]). In 2018, a welcome reform was approved to simplify the system significantly (Box 4). The new structure forms a good basis to initiate further measures to broaden financial as well as guidance support from startups to a stronger focus on survival and medium-term firm growth.

An alternative way to raise more capital is to enable pension funds to increase the share of investments in unlisted Danish equity, amounting to less than $2 \%$ of total assets in recent years (Insurance and Pension, 2018 ${ }_{[52]}$ ). The mandate of pension funds is to deliver high and stable returns on people's savings and should remain so. However, as pension funds have jointly accumulated savings reaching almost 200\% of GDP in 2018, sufficient resources are available to achieve risk diversification. This has allowed the funds to make sizeable and risky investments in large real estate projects, green energy and in firms in developing and emerging economies that seek to contribute to Sustainable Development Goals (SDGs).

At the same time, barriers for more risky investment have diminished in recent years as pension products have been transformed from delivering guaranteed returns to marketbased returns (Financial Supervisory Authority, 2017 ${ }_{[53]}$ ). Financial regulation of pension funds have also changed with the implementation of the European Solvency II directive in 2016. On the one hand, this replaces detailed regulation on portfolio composition with a prudence principle, providing more freedom in choice of investments. On the other hand, it has raised capital requirements and strengthened risk assessment, among others to combat shadow banking from emerging. In Sweden, pension funds have displayed larger appetite for investment in domestic equity (Copenhagen Economics, 2016[54]). Reviewing regulation for pension funds to identify remaining barriers for investments in the domestic equity market should be considered.

Pension funds have also joined forces with public resources in the Growth Fund to establish Danish Growth Capital I and II, a joint investment vehicle with resources of about $0.4 \%$ of GDP invested in entrepreneurs and SMEs through a fund-of-funds structure. Expanding this partnership may also be considered.

\section{Rebalancing taxation to foster investment and entrepreneurship}

Promoting more market-based financing and investment in new businesses and technologies should also be pursued through reforms of the tax system. At the same time, the tax system needs to adapt to ensure that it neither block disruptors, nor gives them undue advantages over incumbents. Steps have already been taken to include the collaborative economy in the regular tax system through automatic reporting of income (e.g. by an agreement with $\mathrm{AirBnB}$ ) and increased deductions to raise incentives to report income from such activities (Box 4). Adjusting the existing tax system step-by-step to new technologies is a sound approach that should be continued.

Denmark's social model is one of an expanded public sector financed by large tax revenues, which are, in terms of GDP, among the highest across OECD countries. The tax system is overall well-designed and efficient, with a limited use of tax expenditures compared to other countries, amounting to about 2.5\% of GDP in 2017 (Danish Ministry of Taxation, $\left.2018_{[55]}\right)$. A series of welcome tax reforms have shifted the tax mix more towards indirect taxes, including environmentally related taxes. As a result, the average tax wedge, the 
difference between the gross pay of the employer and the disposable income of the individual, is close to the OECD average (Figure 19, Panel A), partly reflecting very low social security contributions in Denmark. Likewise, the corporate income tax (CIT) rate has been reduced in response to increasing international tax competition and currently stands at the OECD average of 22\% (Figure 19, Panel B).

Figure 19. The tax wedge and the corporate income tax rate are close to OECD averages

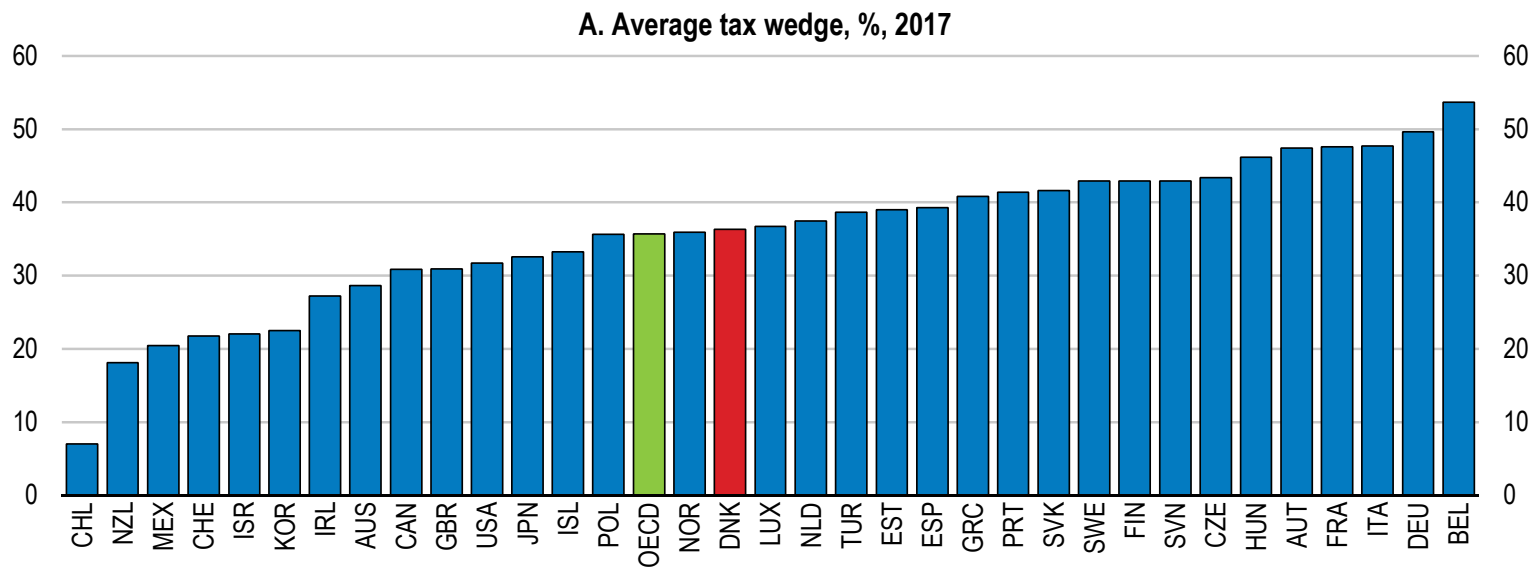

B. Corporate income tax rate, \%, 2018

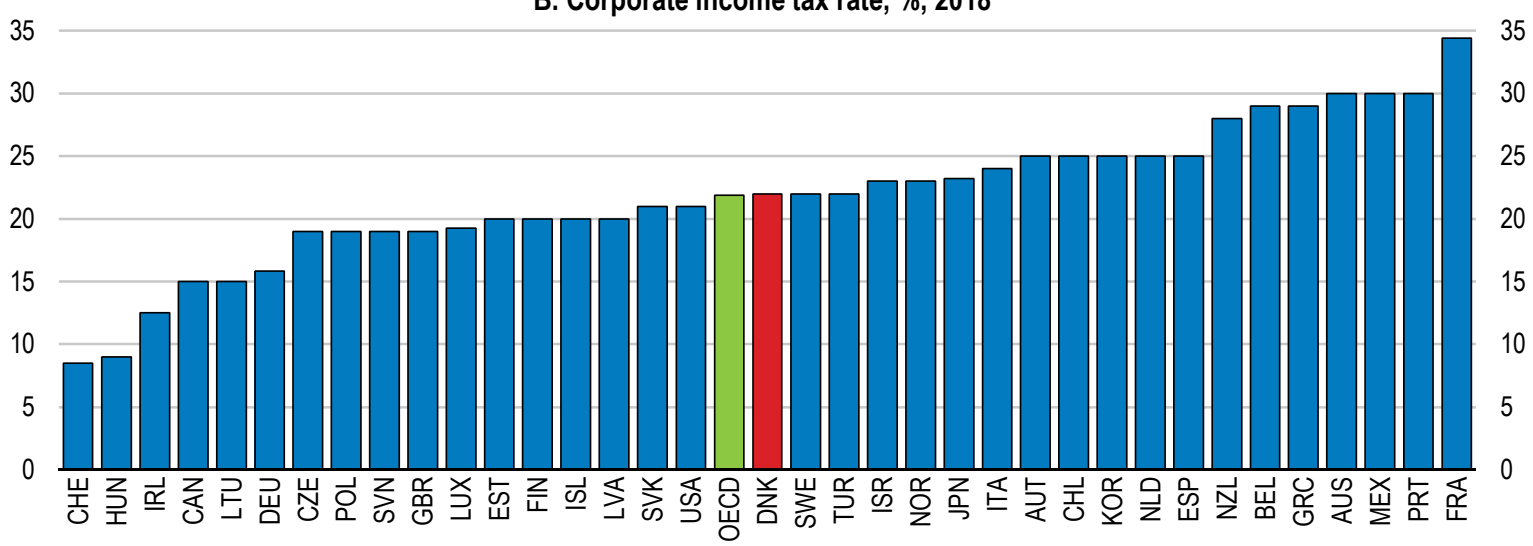

Note: The average tax wedge comprises income taxes plus employee and employer social security contributions (including any applicable payroll taxes) less cash benefits, illustrated for a single household with average wages.

Source: OECD Tax database.

\section{StatLink Anst https://doi.org/10.1787/888933899185}

Nevertheless, decisions to work and invest are also driven by marginal and not only average tax rates. At $56 \%$, the top marginal tax rate on labour income is among the highest across OECD countries (Figure 20). It affected almost $18 \%$ of employment in 2016, but only raised $2.7 \%$ of the total tax revenue. Reducing the top marginal tax rate would boost work incentives and also strengthen incentives for choosing higher-paying education fields with supply shortages (Kreiner, Munch and Whitta-Jacobsen, 2015 ${ }_{[56]}$ ) and entrepreneurship more broadly. Such reform has to be weighed against its implications for inequality. 
Calculations by the Government show that removing the top tax bracket could raise inequality by around one Gini point, which would add to the steady rise in inequality (around five Gini points since the early 1990s, reaching 26 in 2015). Still, compensatory measures could be taken through higher taxation of housing as well as by removing specific measures favouring high-income groups (see Key Policy Insights).

Figure 20. The top marginal tax rate and dividend taxation are high and aligned

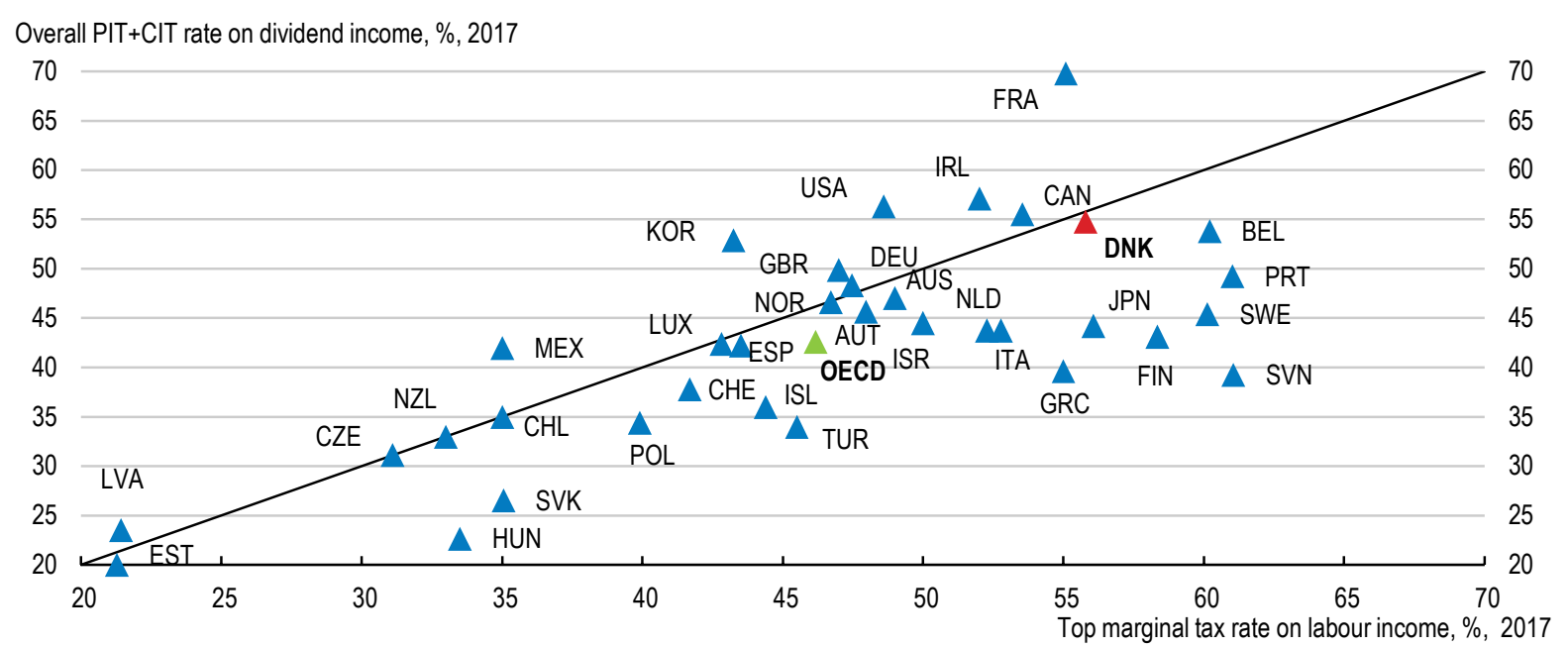

Note: The top marginal tax rate includes personal income tax and employee social security contributions (Allin rate). The overall personal and corporate income tax (PIT+CIT) rate on dividend income reports the overall tax rate on distributed profit, taking into account taxation prior to distribution and at the household level and showing the highest rates.

Source: OECD Tax database.

StatLink הत्ञाs https://doi.org/10.1787/888933899204

Marginal effective tax rates close to $60 \%$ on returns to savings in stocks and other assets also belong to the top across OECD countries (see Key Policy Insights). A business reform package from 2017 introduced tax measures to promote household investment in stocks and entrepreneurs (Box 4), but it will not mitigate the fundamental issue of high marginal tax rates on capital substantially. One element is a tax deduction (investorfradrag) provided to households (individual investors) for investments in unlisted entrepreneurship SMEs that comply with EU definitions and state aid regulation, e.g. being in the startup or growth phase and not in financial difficulties. While the objective to strengthen incentives to invest in startups and more risky projects is justified by market failures, individual households generally lack sufficient funds and information to achieve risk diversification. This is partly addressed by also making the tax deduction available for persons investing through specific investor funds (investorfradragsfonde), which can help to diversify the portfolio. In theory, such a policy could create a financing environment favourable to innovation and startups, but it is not without risks, with investors focussing more on the tax deductions than on returns to investment. Experience from France, which introduced a comparable tax credit, suggests that firms who benefit from the measure did not perform better than those who did not (Cour des comptes, 2015 [57]).

The business package also introduced a new lower tax bracket on dividends and capital gains through a tax-favoured stock account inspired by Sweden and the United Kingdom. 
These measures complicate the tax system significantly and a top statutory tax rate of $42 \%$ still discourages equity investments in startups by large individual investors. As the revenue raised from stock income taxation only amounts to about $2 \%$ of the total tax revenue, consideration should be given to reduce the top rate and simplify the tax scheme. Maintaining a high top dividend tax rate can partly be justified as a means to preserve neutrality across labour and capital income (Figure 20), preventing the manager-owner of a closely-held corporation from categorising income as capital rather than labour to reduce tax payments. Hence, the two tax rates should ideally be reduced in parallel to avoid the need for compensatory measures to prevent manipulation (IMF, 2018 [58] $_{\text {). }}$.

Lowering the high dividend taxation would support a stronger private equity market, but the corporate income tax has a larger impact on firms' investment decisions and access to capital. With the CIT rate being close to the OECD average and neighbouring countries, there is no pressing need to reduce the CIT rate further (Figure 19). A more fundamental reform to introduce an allowance for corporate equity (ACE) (Box 6) is currently being considered by the Government. This would be a welcome reform to reduce the debt-bias in corporate income taxation and remove the double taxation of normal returns (both at the corporate and personal income level). The effective average tax rate on new equity is currently more than 8 percentage points higher than on debt, a gap larger than the EU average (ZEW, 2016 $[59])$. Moreover, introducing an ACE could provide a useful boost to investment. The Government has estimated that an ACE could raise business investments by $6 \%$ in the medium term and lift GDP by $0.7 \%$ in the long run (Danish Ministry of Finance, 2017 $[60])$.

\section{Box 6. Reducing the tax bias to debt finance by an allowance for corporate equity}

Corporate income tax systems generally favour debt finance over equity finance by allowing deductibility of interest payments, while the compensation of equity is not considered as a deductible cost. There is little economic or administrative arguments for this asymmetry (De Mooij, 2012[61]). An allowance for corporate equity (ACE) has been advocated as an attractive measure to achieve tax neutrality with respect to corporate finance structure (Mirrlees et al., 2011 $1_{[62]}$ ). Implementation requires specifying the equity base used to compute the ACE and how it evolves over time as well as setting a "risk-free" rate of return on equity (e.g. the rate on medium-term government bonds).

Currently, Belgium, Italy, Portugal and Turkey apply variants of the ACE, while several other countries have experimented with it in the past (De Mooij, 2012 [61]). The main impediment to a wider adoption is a potentially large revenue loss associated with the narrowing of the CIT base. However, a key argument of the ACE is that it stimulates investment, which can raise economic efficiency and mitigate budgetary costs.

\section{The ACE poses advantages compared to a reduction in the CIT rate}

CIT reform often focus on reductions in the tax rate since the CIT has been found to be one of the most detrimental taxes for growth, especially in small open economies. Introducing an ACE can be a more favourable reform to growth for a number of reasons:

- The ACE effectively transforms the CIT into a tax on economic rents. By allowing a deduction for both interest and the normal return on equity, the ACE system charges no tax on projects with a return that matches the cost of capital. In principle, the ACE can thus remove the tax distortion on the level of investment. 
- Under the ACE the tax base does not depend on details of the depreciation schedule used. The ACE can thus offset distortions associated with misalignment between tax and accounting books (e.g. from accelerated depreciation).

- The economic benefits of the ACE will likely accrue primarily to employees. The main effect of the ACE is to boost investment, which will in turn increase labour productivity and wages.

\section{Implementation requires addressing financing and potential abuse issues}

Reforming the CIT system to apply an ACE represents a large reform with two main practical issues to be addressed:

- Tax revenue loss: The short-run fiscal cost can be reduced substantially by applying the ACE only to new investment (as in Italy and Portugal). This will not reduce the effect on investment, as applying the ACE on existing equity creates a windfall gain.

- Tax planning abuse by multinationals: Equity injections in ACE countries can be passed on as intra-group loans to another country, resulting in double tax deductions. An anti-avoidance framework targeting transactions between related parties is therefore needed (Hebous and Ruf, 2017[63]). Assessments suggest that such measures have been quite effective in Italy, while Belgium suffered from some abuse (Zangari, 2014 ${ }_{[64]}$ ) and recently reformed the ACE to improve its design. Ultimately, a co-ordinated ACE implementation across countries would address the problem.

The ACE not only reduces distortions and boosts growth, it should also benefit workers as the larger capital stock raises labour productivity and wages. The fiscal costs would nonetheless be considerable in the long run (a revenue neutral implementation would require around an 8.2 percentage points increase in the corporate income tax rate) (ZEW, 2016[59]). Alternative more growth-friendly financing should be preferred to avoid additional distortions from a higher corporate income tax rate. The Government envisages an ACE that only applies to new equity, which reduces the medium-term costs substantially, estimated to about $0.1 \%$ of GDP. Italy appears to have implemented this type of ACE quite successful, with an effective anti-avoidance framework to avoid strategic tax planning (Box 6).

Corporate tax reform should also consider limitations on the use of losses carried forward. Small and high-tech companies often experience years of loss making before generating high profits in case of success. To foster more investment in this segment, limitations on the use of losses carried forward in corporate income taxation could be relaxed (Danish Productivity Commission, 2014[65]; IMF, 2018[58]).

Financing the tax cuts could consider a rebalancing of the tax system toward higher tax rates on immovable property (see Key Policy Insights). In addition, a recent reduction in inheritance taxation on family-owned businesses (from 15\% to 5\%) should be cancelled, which is desirable not just for financing reasons. Research has shown that managerial quality and profit rates tend to be lower when the offspring takes over (Bloom and Van Reenen, 2010 [66]; Bennedsen and Nielsen, 2016 [67] $)$. Hence, such differentiated tax rates not only raises the risk of creating loopholes, but also lock in capital in poorly performing firms, harming reallocation to more productive use. Concerns for unwarranted firm liquidations can be addressed by giving family-owned businesses more time to pay 
inheritance tax liabilities and subordinating the liability to other claims on the business during this period.

\section{Fostering knowledge creation and $R \& D$ to boost business innovation}

Denmark is among the "innovation leaders", its innovation system ranking second among EU member States in 2017, behind Sweden and just ahead of Finland (European Commission, 2018 $[68]$ ). However, this very high performance masks a number of weaknesses in the application and commercialisation of innovation outputs. The innovation system is very efficient in some areas such as environment-related technologies where Denmark is a world leader. Innovation strategies launched by the recent Governments put an emphasis on innovation driven by societal challenges such as green growth or health, which will be key for future growth (OECD, 2016[69]]). In May 2018, the Government appointed a growth team of CEOs in green energy and environmental technology to make recommendations to improve the business environment with the objective to use the green transition to boost growth and innovation. Yet, it is also crucial to sustain innovation and productivity growth in other areas, especially given recent evidence that innovation and productivity can provide synergies with environmental goals (Albrizio et al., 2014 ${ }_{[70]}$; Johnstone and Kozluk, 2018 $[71]$ ).

\section{Strong innovation leaders mask weaknesses}

R\&D spending relative to GDP has significantly expanded over the past 20 years and is now among the highest across the OECD, close to the 3\% target set by the Government for 2020 (Table 2). Denmark was the OECD country with the highest proportion of researchers in total employment in 2016. Although the budget was cut by $7 \%$ of total spending in 2016, public expenditure on R\&D remains among the highest in OECD countries relative to the size of the economy. While the budget was raised again in 2017 and 2018 by $1 \%$ and $2 \%$, respectively, these back and forth modifications of public research funding should be avoided to ensure stability. 
Table 2. Denmark ranks high on most innovation measures

Innovation capabilities and performance indicators, 2016 or latest available year

\begin{tabular}{|c|c|c|c|c|c|c|c|}
\hline & $\begin{array}{c}\text { Gross domestic } \\
\text { expenditure on } \\
\text { R\&D as a \% of } \\
\text { GDP }\end{array}$ & $\begin{array}{l}\text { Researchers } \\
\text { per th. } \\
\text { employment }\end{array}$ & $\begin{array}{c}\text { Public } \\
\text { expenditure on } \\
\text { R\&D as a } \% \text { of } \\
\text { GDP }\end{array}$ & $\begin{array}{c}\text { Higher } \\
\text { education } \\
\text { expenditure on } \\
\text { R\&D as a \% of } \\
\text { GDP }\end{array}$ & $\begin{array}{c}\text { Business } \\
\text { expenditure on } \\
\text { R\&D as a \% of } \\
\text { GDP }\end{array}$ & $\begin{array}{c}\text { Top-cited } \\
\text { publications per } \\
\text { mil. population } \\
\text { (2015) }\end{array}$ & $\begin{array}{c}\text { Triadic patent } \\
\text { families per } \\
\text { mil. } \\
\text { population }\end{array}$ \\
\hline Denmark & 2.87 & 14.92 & 0.97 & 0.91 & 1.89 & 385.4 & 49.7 \\
\hline Finland & 2.75 & 14.27 & 0.91 & 0.69 & 1.81 & 255.3 & 52.1 \\
\hline Germany & 2.93 & 9.19 & 0.93 & 0.53 & 2.00 & 166.4 & 55.7 \\
\hline Netherlands & 2.03 & 9.24 & 0.88 & 0.64 & 1.16 & 305.8 & 76.7 \\
\hline Norway & 2.03 & 11.55 & 0.95 & 0.66 & 1.08 & 255.1 & 18.4 \\
\hline Sweden & 3.25 & 14.39 & 0.98 & 0.87 & 2.26 & 291.8 & 62.2 \\
\hline OECD & 2.34 & 8.32 & 0.66 & 0.41 & 1.62 & 144.8 & 40.0 \\
\hline Maximum & 4.25 & 14.92 & 0.98 & 0.91 & 3.64 & 442.3 & 144.0 \\
\hline Minimum & 0.36 & 1.11 & 0.20 & 0.13 & 0.11 & 4.8 & 0.2 \\
\hline
\end{tabular}

Note: Maximum (minimum) corresponds to the best (worst) performing country in the sample of OECD countries for which the indicator can be observed. OECD total is a weighted average, relying on estimates for countries for which the indicator is not available. Top-cited publications are the $10 \%$ most cited papers by scientific field and type of document (articles, reviews and conference proceedings). Triadic patent families are a set of patents filed at the three major patent offices: the European Patent Office (EPO), the Japan Patent Office (JPO) and the United States Patent and Trademark Office (USPTO), counted according to the country of residence of the inventor and to the date when the patent was first registered.

Source: Calculations based on OECD MSTI database; OECD STI Scoreboard 2017.

Looking at the scientific and innovation outcomes of R\&D inputs, research has a high scientific impact, with one of the highest level of top-cited scientific publications per million population (Table 2). Five of Denmark's universities ranked in the top 500 of the Academic Ranking of World Universities (Shanghai ranking, 2015). The outcomes in terms of intellectual property rights are relatively lower, ranking only in the top middle range for triadic patent families per million population, and also showing a relatively low level of trademark and design right applications $\left(\mathrm{OECD}, 2015_{[72]}\right)$. Compared to the very high level of research spending, this points to relatively low technological and commercial applications of research by businesses.

Indeed, although business expenditure on R\&D is well above the OECD average (Table 2), few Danish firms consider themselves as innovative (Deloitte/Kraka, 2017 ${ }_{[73]}$ ). Only 12\% report introducing new-to-market product innovation (OECD, 2017 $[40]$ ). Companies indicate that $7 \%$ of their turnover is provided through sales of innovative (either new-tofirm or new-to-market) products, which places Denmark below the EU average (European Commission, 2018 $\left.{ }_{[68]}\right)$. Performance in terms of high-tech product exports is also below EU average, whereas knowledge-intensive service export performance is slightly above the EU average but has been decreasing over the recent years (European Commission, $\left.2018_{[68]}\right)$.

\section{Business $R \& D$ and innovation are highly concentrated}

The high level of overall business expenditure on R\&D masks a high degree of heterogeneity across firms. In all countries, business $R \& D$ is generally concentrated in a small portion of the business population, typically in large firms (OECD, 2017 [40] $)$. This pattern tends to be particularly marked in Denmark, where only about $25 \%$ of the business enterprise expenditure in R\&D are attributable to SMEs, less than in most OECD countries. 
According to new experimental OECD indicators, the 50 largest R\&D performers in Denmark account for more than $70 \%$ of all business R\&D expenditure (Figure 21 ). The top Danish business R\&D investor, Novo Nordisk, spends more than five times more on R\&D than any other corporate group headquartered in Denmark (Table 3).

Figure 21. Business R\&D is highly concentrated in a small number of firms

Top 50 and top 100 business R\&D performers, as a percentage of domestic business R\&D expenditure, 2014

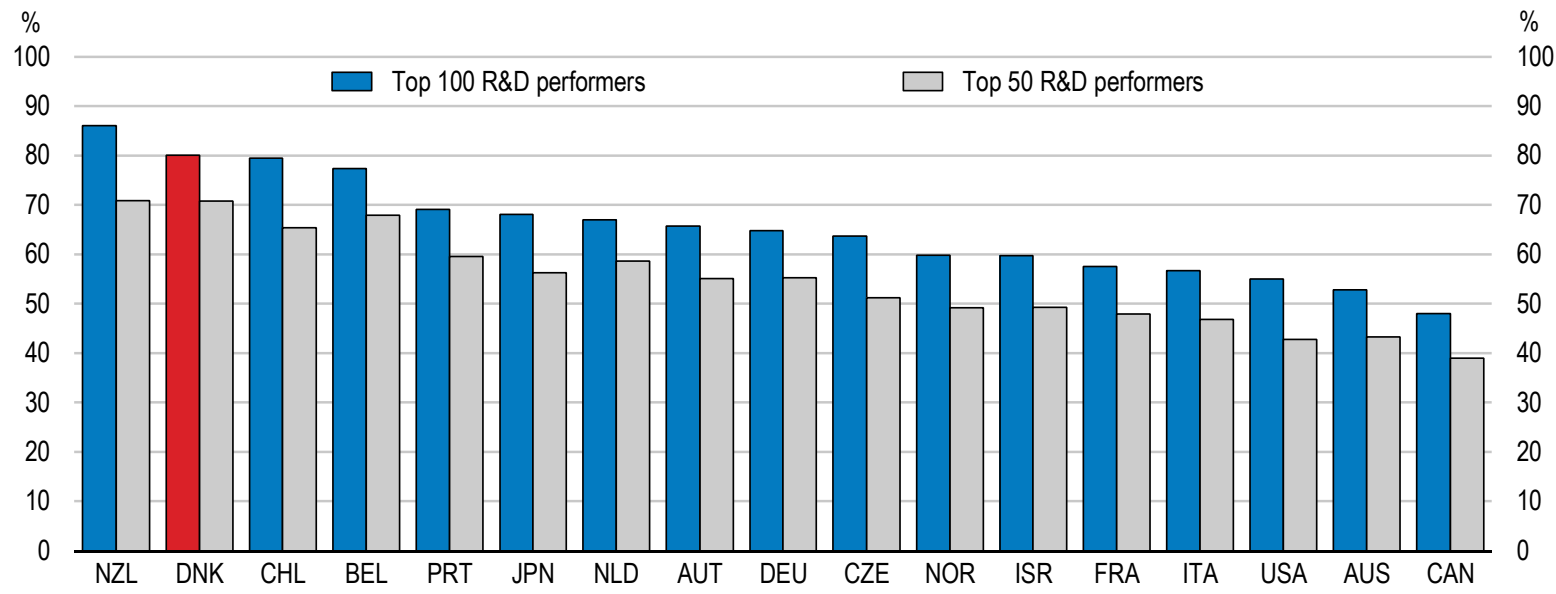

Note: Experimental indicator based on a distributed approach to the analysis of microdata across different jurisdictions. For more information, see http://oe.cd/microberd. For Austria, Belgium, Germany, France and Italy figures refer to 2013. For Portugal, figures refer to 2012

Source: OECD STI Scoreboard 2017.

StatLink त्गाIs https://doi.org/10.1787/888933899223

Business research and innovation is moreover highly concentrated in a few industrial sectors and technological areas. Among the top 30 Danish corporate R\&D investors, ten operate in the pharmaceutical and biotechnology sector, including three in top five (Table 3). This concentration is also prominent on the innovation output side, featuring a high and increasing level of specialisation in environment-related technologies (Figure 22). These high levels of concentration and specialisation result in Denmark being at the forefront of innovation in certain technologies such as health and environment, with a number of health- and environment-related patents compared to its population among the highest in OECD countries. 
Table 3. Danish R\&D investors is strongly dominated by pharmaceutical companies

Danish companies among the top 2500 R\&D investors worldwide, 2017

\begin{tabular}{lrrl}
\hline \multicolumn{1}{c}{ Company } & World Rank & R\&D (EUR million) & \\
\hline NOVO NORDISK & 68 & 1931.7 & Pharmaceuticals \& Biotechnology \\
DANSKE BANK & 287 & 416.1 & Banks \\
H LUNDBECK & 330 & 350.7 & Pharmaceuticals \& Biotechnology \\
DANFOSS & 383 & 296.8 & Industrial Engineering \\
LEO PHARMA & 441 & 253.7 & Pharmaceuticals \& Biotechnology \\
NOVOZYMES & 468 & 235.2 & Pharmaceuticals \& Biotechnology \\
VESTAS WIND SYSTEMS & 487 & 225.0 & Alternative Energy \\
FERRING PHARMACEUTICALS & 654 & 155.3 & Pharmaceuticals \& Biotechnology \\
GRUNDFOS & 702 & 143.1 & Gas, Water \& Multiutilities \\
WILLIAM DEMANT & 107.9 & Health Care Equipment \& Services \\
GN STORE NORD & 890 & 106.5 & Technology Hardware \& Equipment \\
ASCENDIS PHARMA & 898 & 98.9 & Pharmaceuticals \& Biotechnology \\
ARLA FOODS & 950 & 87.0 & Food Producers \\
LEGO & 1032 & 78.3 & Leisure Goods \\
COLOPLAST & 1128 & 72.1 & Health Care Equipment \& Services \\
SIMCORP & 1192 & 63.5 & Software \& Computer Services \\
CHR HANSEN & 1313 & 62.1 & Pharmaceuticals \& Biotechnology \\
NKT & 1338 & 58.2 & Electronic \& Electrical Equipment \\
BAVARIAN NORDIC & 1406 & 54.7 & Pharmaceuticals \& Biotechnology \\
ALK ABELLO & 1471 & 51.4 & Pharmaceuticals \& Biotechnology \\
TDC & 1525 & 41.6 & Fixed Line Telecommunications \\
MHI VESTAS OFFSHORE WIND & 1793 & 36.0 & Alternative Energy \\
BANG \& OLUFSEN & 1993 & 35.6 & Leisure Goods \\
KMD & 2008 & 34.4 & Software \& Computer Services \\
\hline NILFISK HOLDING & 2053 & 33.8 & Real Estate Investment \& Services \\
ROCKWOOL INTERNATIONAL & 2086 & 31.9 & Construction \& Materials \\
ZEALAND PHARMA & 2180 & 29.0 & Industrial Transportation \\
DSV & 2267 & 28.5 & Industrial Engineering \\
FLSMIDTH & 2313 & 27.6 & Software \& Computer Services \\
\hline SITECORE HOLDING II & 2335 & & \\
\hline
\end{tabular}

Note: Companies headquartered in Denmark among the top 2500 corporate R\&D investors worldwide. World rank corresponds to the company rank in terms of $R \& D$ expenditure of corporate investors worldwide. $R \& D$ expenditure are consolidated at the group level and based on information taken from the companies' latest published accounts, corresponding either to calendar year 2017 or to financial year ending on 31 March 2018. Industry corresponds to the 3-digit Sector in the Industry Classification Benchmark developed by Dow Jones and FTSE.

Source: EU R\&D Scoreboard data.

By contrast, Denmark is lagging behind in other technological areas such as ICT-related technologies (Figure 23; Figure 24). This may partly be a consequence of being a small economy, which has made the choice to specialise in certain technological areas. However, with innovation efforts concentrated in some sectors, Denmark may miss other technologies that will be key in the future, for example to step in the future waves of digital transformation. Widening the scope of innovation and allowing more firms to invest in these technological areas is therefore crucial to prepare for the future, especially as new ICT-related technologies can help address challenges in other areas such as health and energy. 
Figure 22. Denmark's patents are highly specialised in environment technologies

Revealed technological advantage (RTA) in environment technologies, 2002-05 and 2012-15

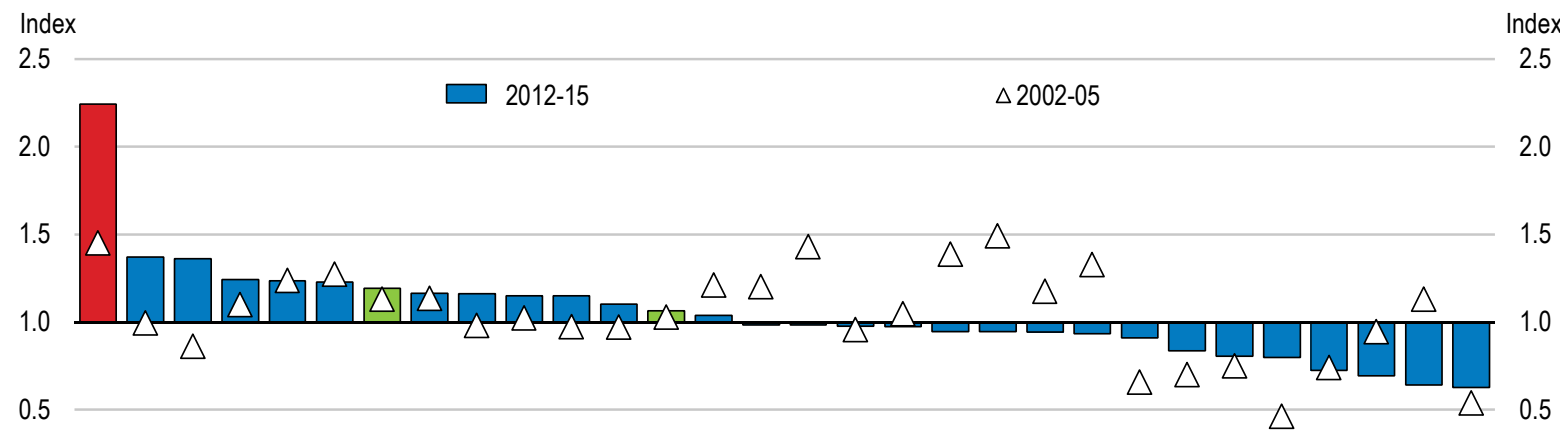

0.0 y

Note: Index based on IP5 patent families. The revealed technological advantage index is calculated as the share of patents of an economy in a particular technology area relative to the share of total patents belonging to the economy. The RTA index is equal to zero when the economy has no patent in a given field, equals 1 when the economy's share in the technology field is equivalent to its share in all fields, and rises above 1 when specialisation is observed. Data refer to IP5 families, by filing date, according to the inventors' residence using fractional counts.

Source: OECD STI Scoreboard 2017.

StatLink त्गा5म https://doi.org/10.1787/888933899242

Figure 23. Denmark's relative performance in patent filings is unequal across different technological areas

IP5 patent families by technology per thousand population, 2012-2015

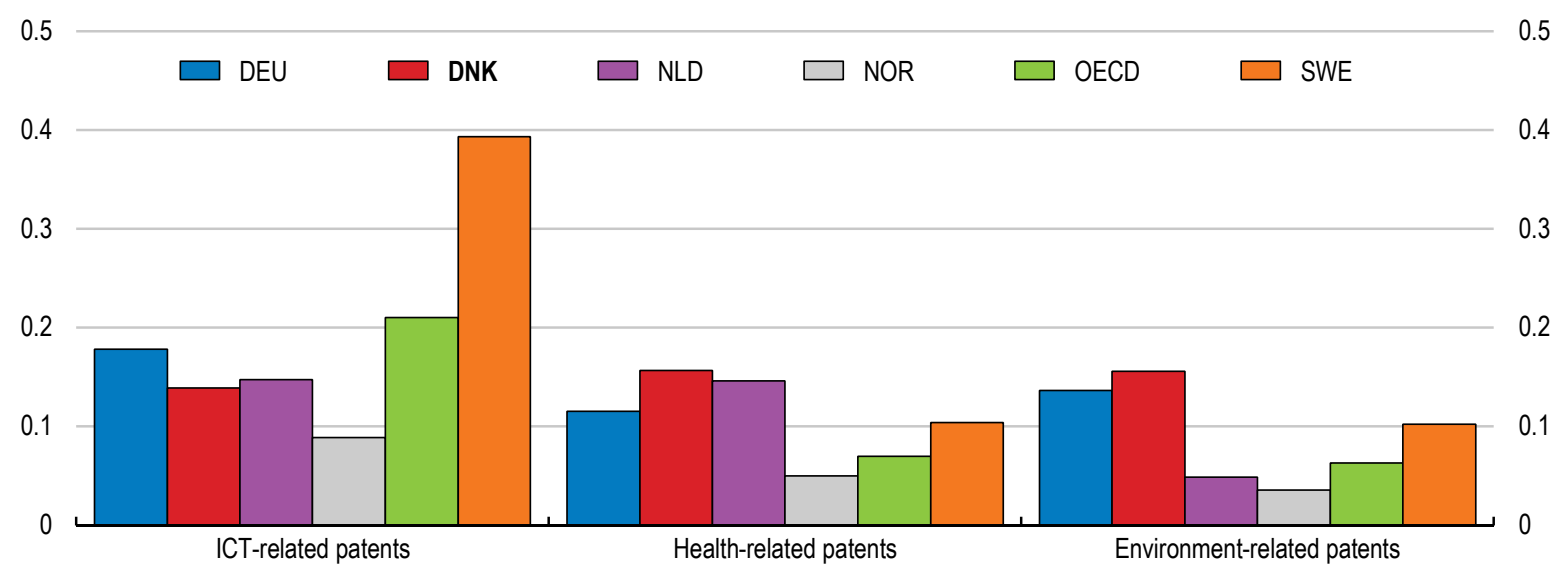

Note: Data refer to IP5 families, by filing date, according to the inventors' residence using fractional counts. The figures refer to patent families filed in 2012-2015 and population in 2015.

Source: Patent data from OECD STI Scoreboard 2017, and population series from OECD MSTI Database 2017. 
Figure 24. Information industries productivity and innovation performance relative to other sectors are lower than in most countries

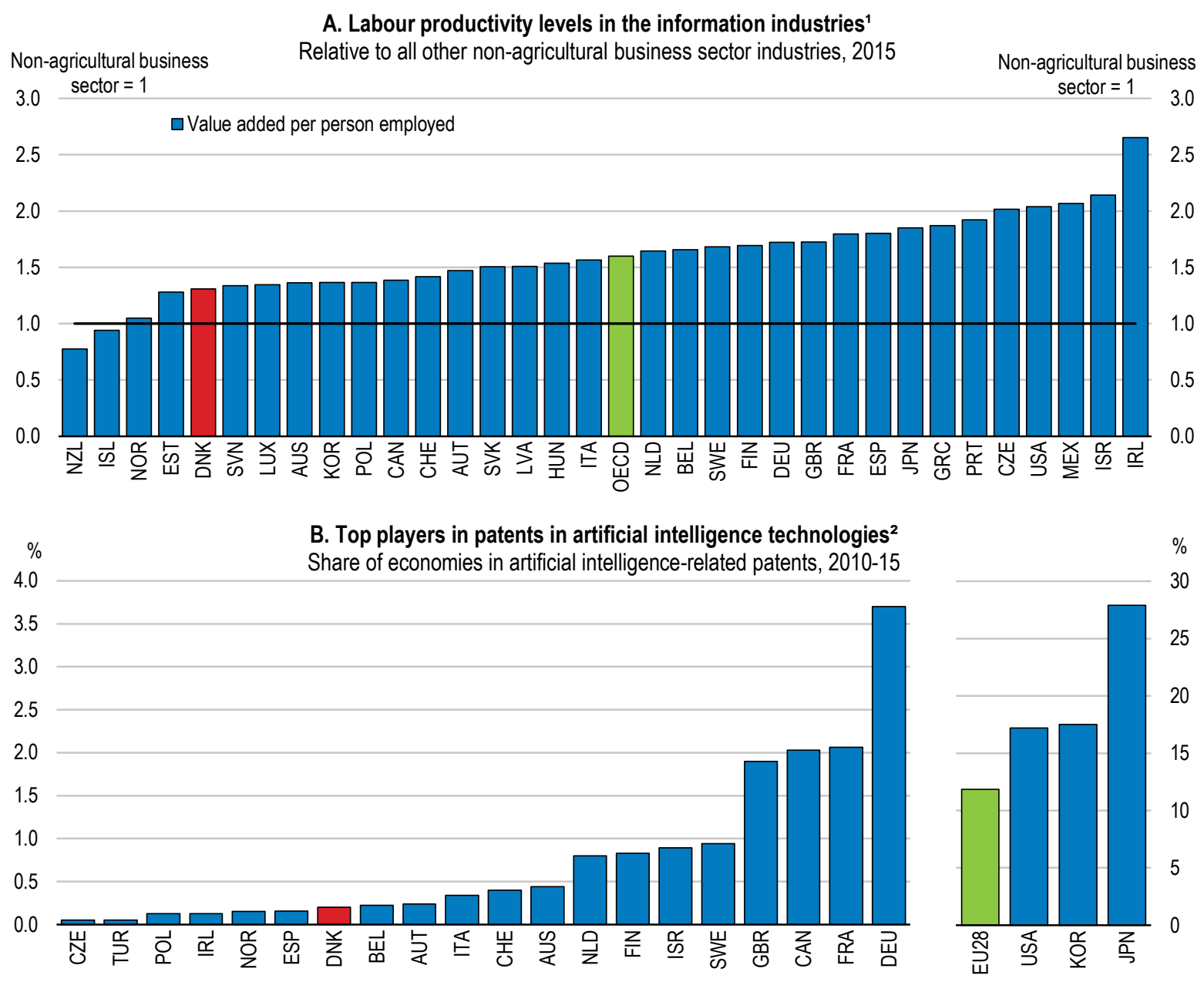

Note: Panel A: Information industries are defined according to ISIC Rev.4: "Computer, electronic and optical products" (Division 26), "Publishing, audiovisual and broadcasting" (58 to 60), "Telecommunications" (61) and "IT and other information services" $(62,63)$. Panel B: Data refer to the number of IP5 patent families in artificial intelligence (AI), by filing date and inventor's country.

Source: OECD STI Scoreboard 2017.

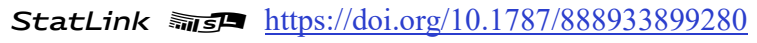

\section{Improving instruments to foster innovation within firms}

Denmark stands below the OECD median in terms of the overall generosity of its public support to business innovation as a percentage of GDP (Figure 25). Direct government funding of business R\&D mainly benefits large firms, partly because SMEs and young innovative firms are less likely to undertake R\&D-based forms of innovation. Initiatives like the creation of the Market Development Fund in 2012, which aimed to help firms to bring their new products to the market by supporting the development process just before commercialisation, have been effective in raising innovation returns in SMEs (Irisgroup, $\left.2015_{[74]}\right)$. A recent political agreement plans to simplify the existing range of business support schemes (Box 4), which will merge the Market Development Fund with the 
Innovation Fund from 2019. This merger of the different funds is welcome as it will likely simplify public support for innovation, but the reform should make sure that the innovation expertise support provided to businesses is maintained.

Figure 25. The policy mix in public support for business $R \& D$ increasingly relies on fiscal incentives, although they remain at a moderate level

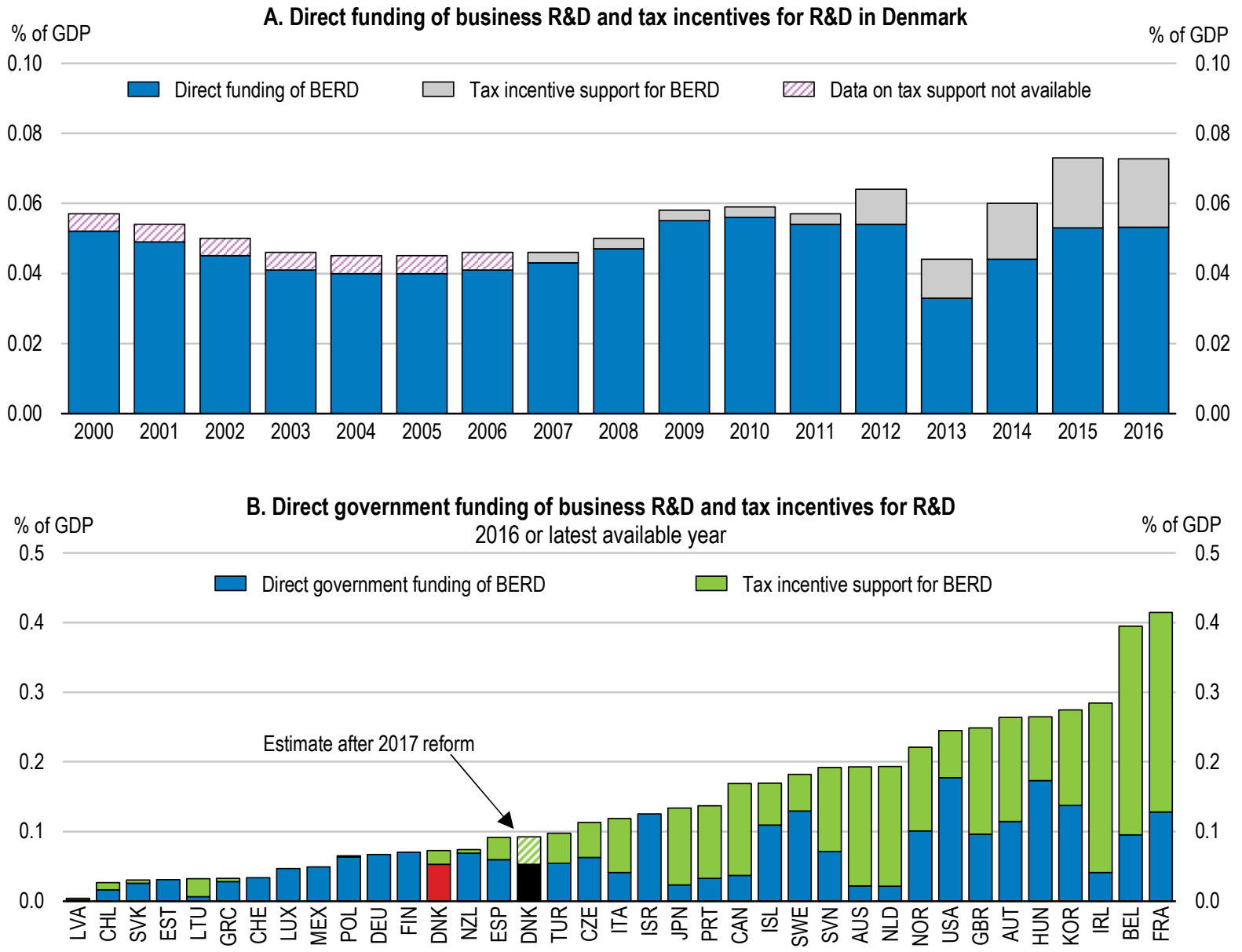

Note: Panel B shows two bars for Denmark, the first one (red bar) corresponds to the actual cost of public support to business R\&D relative to GDP in 2016, whereas the second one (black bar) shows the estimated cost after the full implementation of the 2017 reform (from 2026), based on the projections of the Danish Government (2017 [75]).

Source: OECD, R\&D Tax Incentive Indicators, http://oe.cd/rdtax.

StatLink त्ञाs https://doi.org/10.1787/888933899299

Although direct government funding of business R\&D still constitutes the bulk of public support to business $R \& D$, an increasing share of public support is provided through $R \& D$ tax incentives (Figure 25, Panel A). The current level of tax incentive support for business R\&D is, however, well below the OECD median (Figure 25, Panel B). Indeed, the current general tax deduction scheme offers an accelerated depreciation for machinery and equipment related R\&D expenditure, but until 2018 no enhanced tax deductions (i.e. higher than $100 \%$ ) or credits was offered for current $R \& D$ expenditures, whereas these typically constitute the largest cost component in other countries. Since 2012, a scheme for loss- 
making firms has been in place (skattekreditordningen), where companies receive a refundable tax credit corresponding to $22 \%$ (corresponding to the corporate income tax rate) of any deficit-related R\&D expenses up to a ceiling of EUR 3.4 million. This type of scheme tends to shift the support towards young firms facing liquidity problems in the startup phase, when R\&D activities have not yet resulted in income $\left(\mathrm{CPB}, 2014_{[76]}\right)$. This is welcome as it avoids the common criticism made to R\&D tax credits that, although they avoid the "picking winners" problem, which can be associated with direct grants, they may nevertheless favour incumbents at the expense of new firms (OECD, 2013 ${ }_{[4]}$; Bravo-Biosca, Criscuolo and Menon, 2016 $\left.{ }_{[77]}\right)$.

Recent reform (Box 4) will increase R\&D tax incentives by introducing enhanced tax allowance for current $R \& D$ expenditure. The enhanced tax allowance rate will gradually increase from $1.5 \%$ in 2019 to $10 \%$ in 2026 (Box 4). The estimated annual cost of this reform is EUR 60 million (approximately $0.02 \%$ of GDP) (Danish Government, 2017 ${ }_{[75]}$ ). Although this would roughly represent a doubling of the current support provided through $\mathrm{R} \& \mathrm{D}$ tax incentives, the tax allowance rate will remain relatively low by international standards (Figure 25). While an assessment of the reform is needed, the Government should potentially consider increasing further the support through R\&D tax incentives. The schemes should be carefully designed to take into account heterogeneity among potential R\&D performers (Appelt et al., 2016 $6_{[78]}$ ). Incremental R\&D tax credits based on the increase in R\&D over time should be considered as volume-based credits, although they have the advantage of simplicity, tend to benefit mainly large firms. Raising the ceiling on the scheme for loss-making firms could also be considered in order to reach significant impact in terms of shifting public support to young innovative firms. This may also require an increase in direct public funding, as even if the $R \& D$ tax incentives contain refunds for loss-making companies, young firms may not fully benefit from the schemes if they lack the upfront funds to start an innovative project (Busom, Corchuelo and Martinez-Ros, $\left.2014_{[79]}\right)$.

\section{Improving cooperation between universities and the business sector}

Given the high weight of public institutions in R\&D expenditure, linkages between public and private innovation actors are a key factor to enhance the economic returns from research expenditure. Evidence shows that more intensive collaboration between firms and universities is associated with higher productivity outcomes at the firm level (Danish Productivity Commission, 2013 [80]; Andrews, Criscuolo and Gal, 2015 [81]). Weak collaboration and spillovers from public research to businesses constitute an important barrier for business investments in intangible assets (Thum-Thysen et al., 2017 ${ }_{[41]}$ ).

Collaboration between universities and industry needs strengthening in Denmark. The share of higher education research financed by industry stood at $2.6 \%$ in 2015 , well below the 5.6\% OECD average (Figure 26). Commercialisation of the institutions' research results, which is a good indicator of knowledge transfers from public research institutions to the rest of the research community, is also limited. The share of patent applications from public research institutions has more than doubled between 2003 and 2013, but remains below the OECD average (OECD, 2016 $\left.6_{[69]}\right)$. 
Figure 26. Private funding of public $R \& D$ is very low

Share of higher education sector research financed by industry, 2015

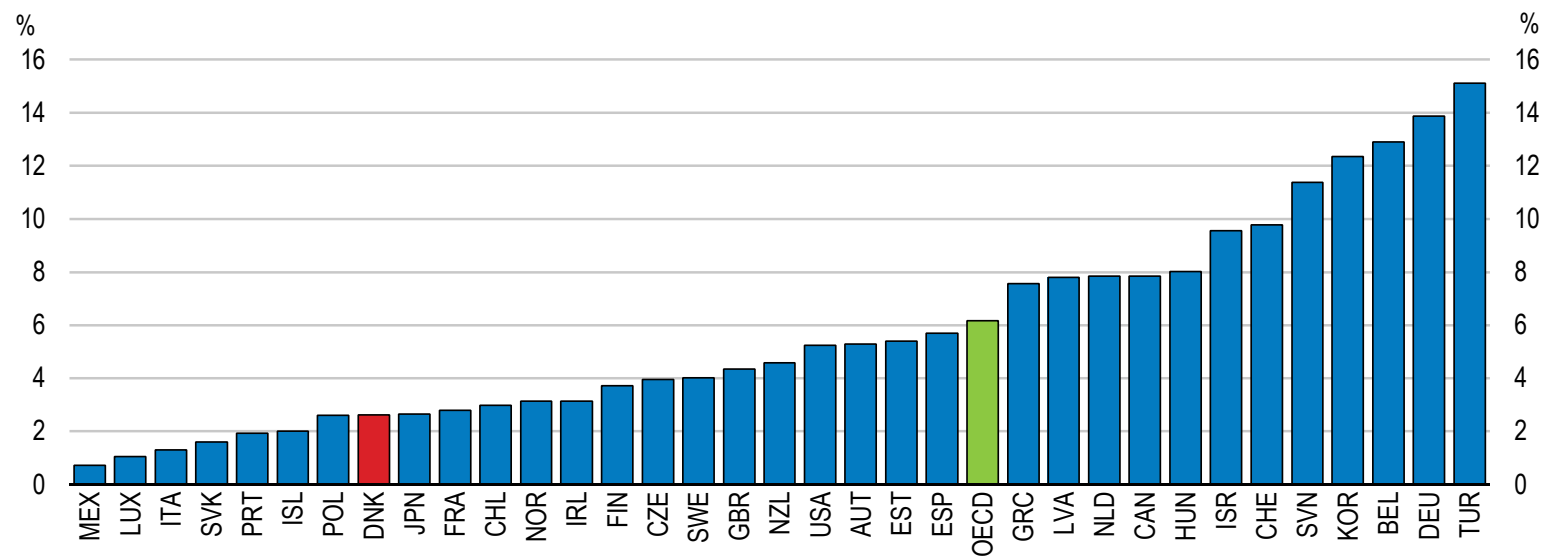

Source: OECD Main Science and Technology indicators.

StatLink ज्ञाs https://doi.org/10.1787/888933899318

In December 2017, a new research and innovation strategy was launched, including initiatives to strengthen research in technology and technology transfers from universities to business. This includes an inspection of technology transfers efforts from universities, as well as the legislation surrounding these transfers, with the aim to remove any possible barriers (Danish Ministry of Higher Education and Science, 2018 ${ }_{[82]}$ ). This initiative is welcome as strengthening the intellectual property right policies of universities would help give researchers stronger incentives to commercialise their research (Grimpe and Mitchell, $\left.2016_{[83]}\right)$.

\section{Enabling businesses to thrive in the digital age}

The digital transformation not only offers new technological and business opportunities, it also facilitates communication and knowledge sharing, which in turn leads to a higher pace of innovation and technological change. Digitalisation brings opportunities for the business sector and is likely to be a major driving force of future productivity growth. Digital technologies also pose new challenges for taxation, digital security and data privacy, which have to be addressed in order to favour trust in these technologies without which a large uptake cannot take place.

\section{Boosting digital adoption in firms to spur productivity growth}

Although Denmark is a highly digitalised country, the use and implementation of new digital technologies by businesses remains a challenge, especially for small firms. The diffusion of basic digital technologies such as broadband connection or having a website is almost complete. Firms are relatively less advanced in the adoption of more advanced technologies such as the use of enterprise resource planning or customer relationship management software, radio frequency identification technology or big data analysis (Figure 27, Panel A) (Statistics Denmark, 2018 ${ }_{\text {[84] }}$; Højbjerre Brauer Schultz, 2017 [85]). These technologies are likely to boost productivity, not only within the adopting firm but also in other firms thanks to spillover effects (Andrews, Nicoletti and Timiliotis, 2018[86]). 
As in most OECD countries, SMEs are lagging behind in ICT usage (Figure 27, Panel B) (OECD, 2017 $[17]$; Danish Ministry of Industry Business and Financial Affairs, 2017 $[87]$ ), which might be due not only to lower investment capacity but also to lower ability to use and benefit from technologies.

Figure 27. Adoption of digital technologies is uneven across technologies and firm size

A. Share of businesses adopting different digital technologies, 2017
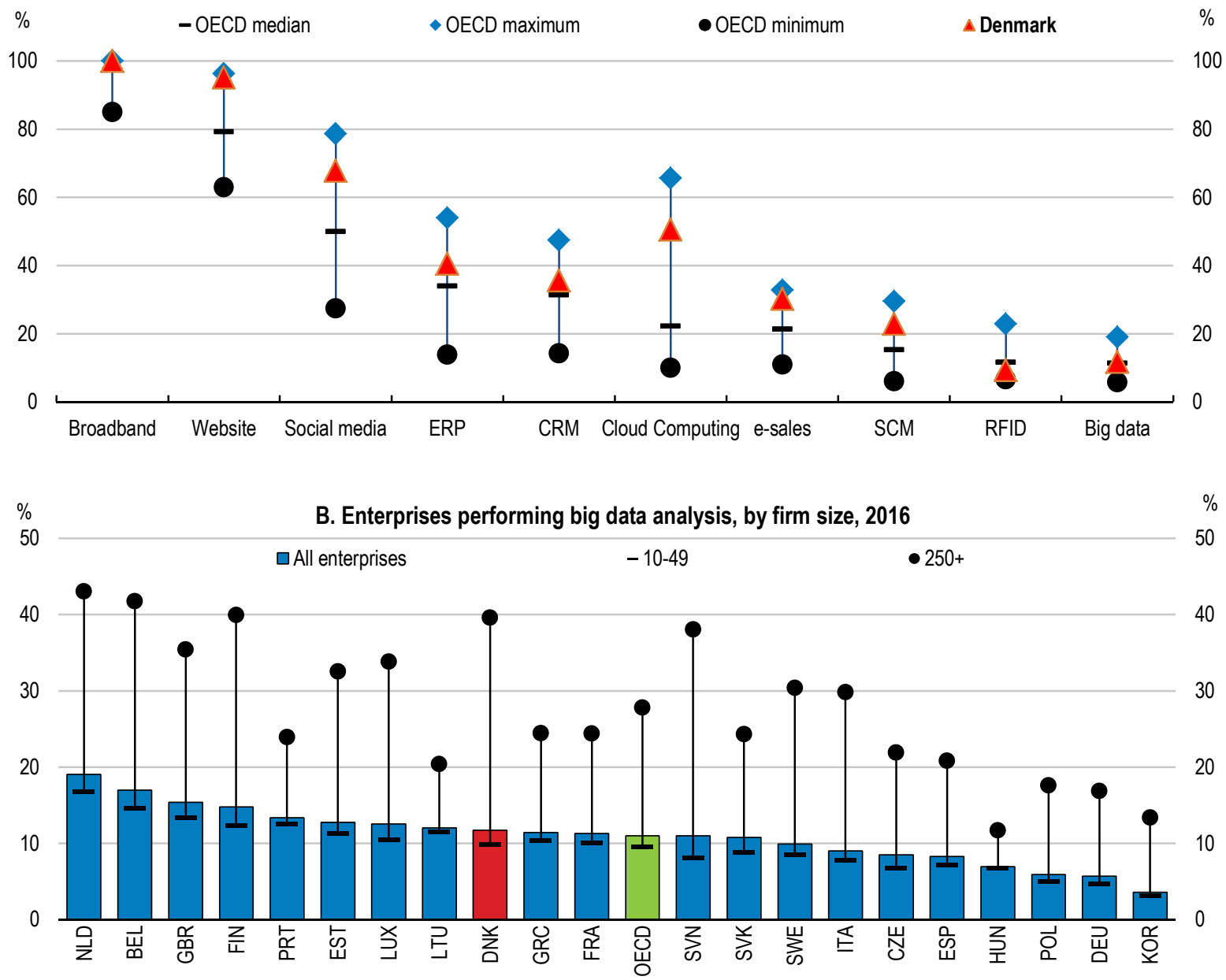

Note: In Panel A, data cover 26 OECD countries and correspond to the share of businesses with ten or more employees with broadband connection (fixed or mobile); with a website or home page; using social media; using Enterprise Resource Planning (ERP) software; using Customer Relationships Management (CRM) software; purchasing cloud computing services; receiving orders over computer networks; sharing electronically SCM information with suppliers and customers; using Radio Frequency Identification (RFID) technology; and having performed big data analysis (2016 data).

Source: OECD ICT Access and Usage by Businesses Database; OECD Digital Economy Outlook 2017.

StatLink त्राजम https://doi.org/10.1787/888933899337

Indeed, a number of studies conducted on firm level data suggest sizeable potential productivity impacts from adopting new ICT and digital technologies (OECD, 2018 $\left.{ }_{[88]}\right)$. In the case of Denmark, all three components of ICT spending (hardware, software and communication equipment) have generally increased productivity at the firm level (Box 5). 
This is in line with previous results, showing that Danish ICT intensive firms are more likely to engage in innovation activities and have higher productivity for the period 20072010, with a significant part of this being explained by ICT-induced innovation (Fosse, Jacobsen and Sørensen, 2013 [89]). Likewise, among Danish firms with at least 20 employees the more digitalised firms generate a larger share of value added from exports and have $6 \%$ higher productivity than less digitalised firms on average, controlling for differences in size, industry, and capital stock (Danish Ministry of Industry Business and Financial Affairs, $\left.2017_{[87]}\right)$.

Given that differences in technology adoption are likely to result in differences in productivity performance, policy makers should aim to reduce obstacles to technology investments and digital diffusion. Ensuring global connectivity for all is an important first step, but fostering complementary investments in knowledge-based capital such as R\&D, digital and managerial skills, and organisational change, especially in SMEs are also necessary. Findings from recent analysis suggest that even if expected gains are lower than in other countries, there is scope for policy to raise firms' incentives to adopt digital technologies, in particular by further reducing employment protection legislation (Box 7).

\section{Box 7. How much scope for structural reform to boost digital adoption in firms in Denmark?}

\section{Overview of the framework}

Recent OECD research has identified structural and policy factors that may accelerate the adoption of digital technologies by firms (Andrews, Nicoletti and Timiliotis, 2018 $8_{[86]}$ ). The study analyses three sets of digital technologies that are far from a complete diffusion rate and that are likely to be relevant for productivity growth within firms: Cloud Computing (distinguishing standard and advanced use), Enterprise Resource Planning (ERP) software and Customer Relationship Management (CRM) systems.

The policy factors considered include managerial practices, education and training, product market regulations (PMR), employment protection legislation for regular contract (EPL), insolvency regimes and risk capital markets. Economic effects of policy reforms are captured by comparing industries that are naturally more or less exposed to them (depending for example on the level of firm turnover rate or knowledge intensity), following Rajan and Zingales $\left(1998_{[90]}\right)$. The industry-level data applied covers 25 European countries.

\section{Effect of reforms on digital adoption rates}

This framework can be used to tentatively simulate the potential benefits of changes in selected structural and policy factors on adoption rates of various digital technologies. Figure 28 presents the estimated gains in adoption of high versus low exposed industries of a move to the best practice observed in the sample for Denmark and other countries included.

Compared to other countries, Denmark has relatively low scope to boost digital adoption through reforms to reduce administrative burdens for startups. Some sizeable gains in terms of digital adoption may be achieved by reducing the strictness of employment protection on regular contracts, i.e. the regulation of individual and collective dismissals, or increasing the (perceived) quality of management schools, even if expected gains are lower than in the other countries. Reducing EPL to the level of the United Kingdom would for example 
reduce the difference in adoption rate of ERP software between highly exposed industries and marginally exposed industries by around 1.2 percentage point.

\section{Figure 28. Potential increase in digital adoption rate from structural policy reforms}

Differential impact between industries with high and low exposure to the policy

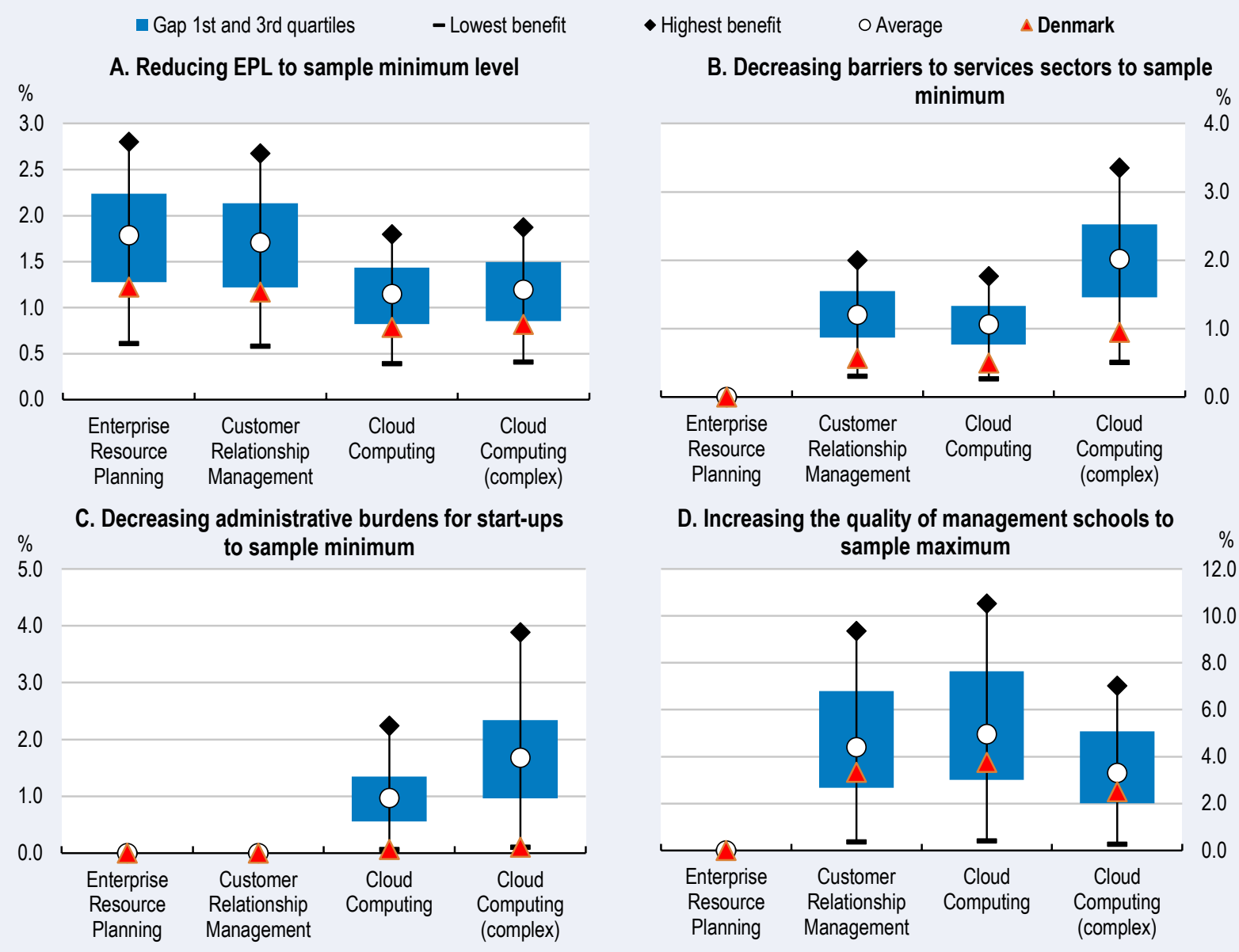

Note: The graphs show the ceteris paribus differential increase in digital adoption rates from decreasing EPL (Panel A), barriers to services sectors (Panel B), and administrative burdens for startups (Panel C) to sample minimum; or increasing the quality of management school (Panel D) to sample maximum between industries with high (i.e. 75th percentile) and low (i.e. 25th percentile) turnover rates (Panel A, B, C) or knowledge intensity (Panel D). Effects that are not significant are reported as nil.

Source: Calculations based on Andrews, Nicoletti and Timiliotis (2018[86]).

StatLink त्ञाज https://doi.org/10.1787/888933899356

\section{Fostering high-quality digital infrastructure}

The broadband infrastructure is highly developed, ranging in the top quartile of OECD countries for fixed and mobile subscriptions per inhabitant (Figure 29). This enables a widespread use of digital technologies, with few differences across age groups, gender or geographical areas $\left(\mathrm{OECD}, 2017_{[17]}\right)$. Yet, with respect to the deployment of high-speed connection (such as fibre-subscriptions) or machine-to-machine subscriptions, Denmark 
ranks below neighbouring countries. The Government has taken a number of initiatives aiming at increasing the coverage and speed of broadband connection, which take as a point of departure that broadband development should be market-driven and regulation should be technology-neutral. These initiatives are welcome, although complementary initiatives may be necessary to allow the deployment of most advanced technologies, where Denmark is lagging. For instance, the deployment of Internet Protocol version 6 needs to be strengthened in the longer term to allow the uptake of the next wave of digital technologies (Box 8).

Figure 29. Digital access is high, but deployment of the latest technologies is low

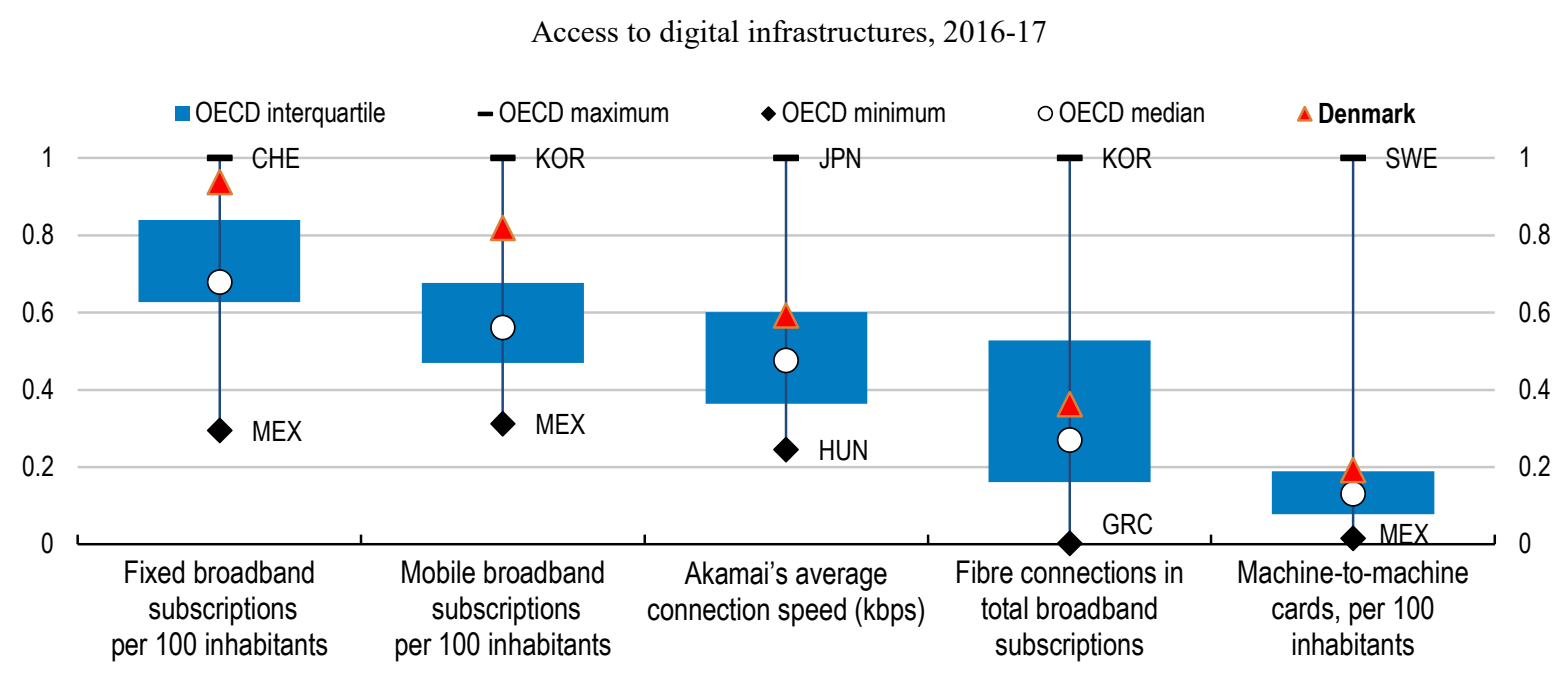

Source: OECD Broadband statistics. 
Box 8. Preparing for the next waves of digital innovation with the deployment of IPv6

Encouraging the deployment of Internet Protocol version 6 (IPv6) is crucial to prepare the country for future disruptions (Figure 30), as this technology will be key to support the proliferation of connected devices and sensor networks and the uptake of the Internet of Things (OECD, 2017 $[17])$.

Figure 30. IPv6 adoption is very low in Denmark

Country adoption of Internet Protocol version 6 (IPv6), 2016

$\%$

60

50

40

30

Google

$\square$ Google $\square$ APNIC $\square$ Akamai 5

西

7

20

10

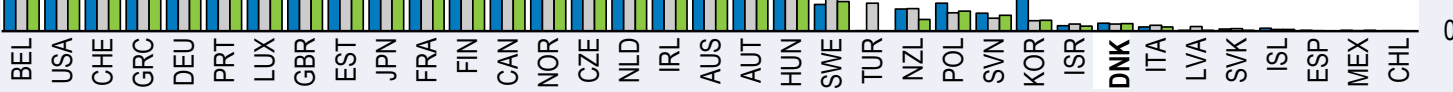

Note: Country adoption of IPv6 in 2016 according to three different methodologies.

Source: OECD Digital Economy Outlook 2017.

StatLink Ants https://doi.org/10.1787/888933899394

The Government can play a role as a large user by requiring equipment that is compatible with this new standard, which may in turn facilitate the development of human capital related to the deployment of this technology and indirectly stimulate private investment (OECD, 2014[91]). In the United States, for example, the Government has mandated adoption of IPv6 first within the Department of Defence and later in other federal agencies. In Sweden, the Government has established a goal that all Swedish authorities and municipalities should be reachable over IPv6 and launched a program of informational awareness in the public sector, providing practical information on how to deploy on IPv6 (OECD, 2014[91]; Hersaeus and Svahn, 2011 [92]).

\section{Favouring superior digitalisation of the public sector and open government data}

Although the public sector is highly digitalised in terms of interactions of individuals with e-government services, further initiatives on digital government are needed to improve current practices and procedures regarding open government data (Figure 31). In 2012 Denmark launched a basic-data initiative, focusing on providing free and easy access to basic data registries such as geographic and real property data, both for public sector units and businesses. While more data is gradually being made available, other countries have managed to make a wider range of government data freely accessible in one platform. For 
instance, Canada, France and the United Kingdom provide access to data on prices, quantities and outcomes in areas such as transport, law and justice and agriculture.

Figure 31. Denmark is a frontrunner in e-government use but lags in data openness
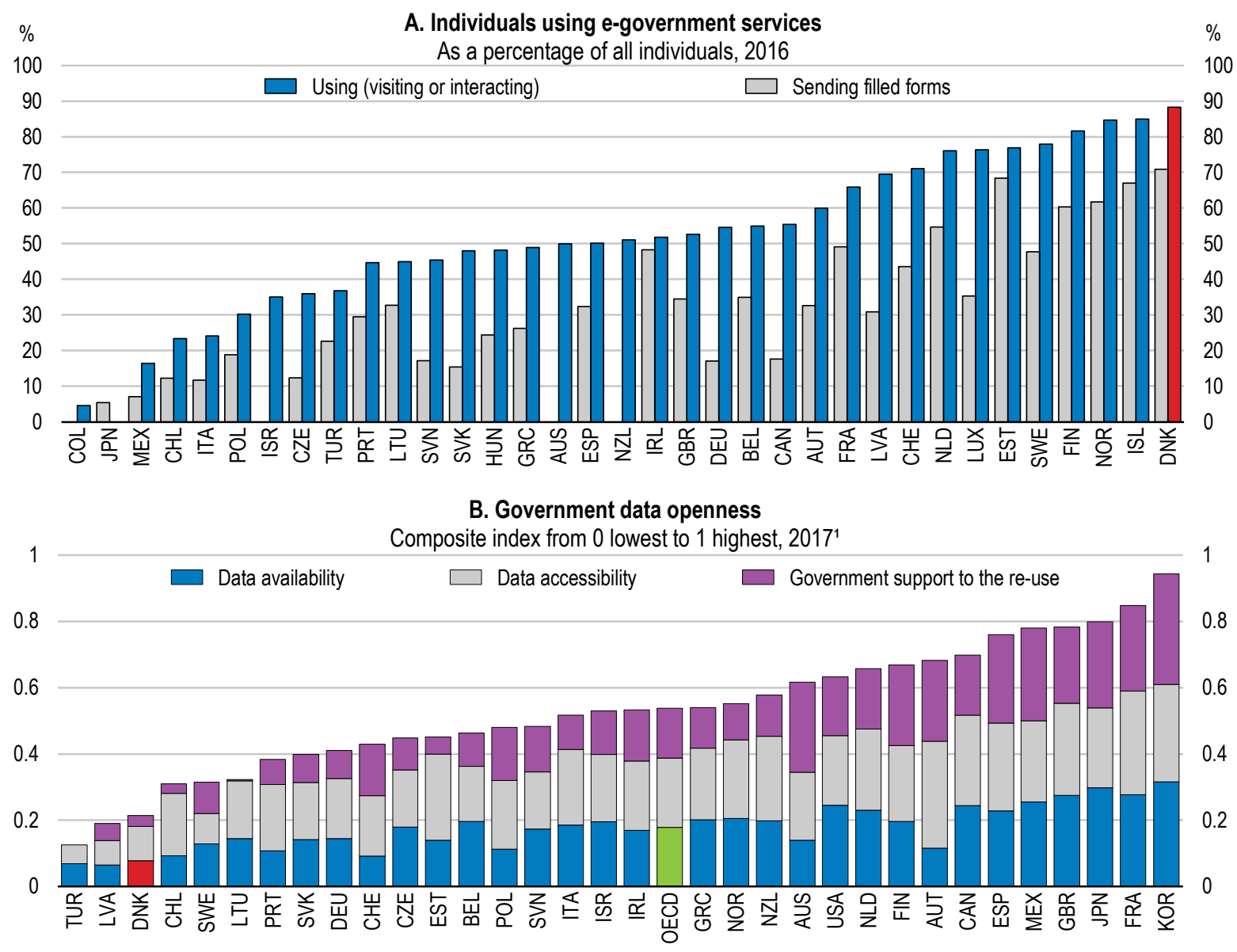

1. Responses represent countries' own assessments of current practices and procedures regarding open government data. Data refer only to central/federal governments and exclude open government data practices at the state/local levels.

Source: OECD Digital Economy Outlook 2017; OECD Survey on Open Government Data.

\section{StatLink 세에 https://doi.org/10.1787/888933899413}

Recent digital initiatives by the Government (Box 4) aim at fostering further open access to public-sector basic data, in particular by making more public data available (e.g. weather data) and investing in technologies (e.g. cloud computing and artificial intelligence) to reuse these data. This should create new opportunities for research or innovation, including by businesses. Indeed, given the long history of building register-based data and the wealth of data collected, Denmark should do more in this area since it could foster innovative services to the benefit of households. Early adopters of open government data initiatives, such as Korea, France, the United Kingdom or the United States have been able to introduce and implement a large range of policies to promote data availability, accessibility and reuse. One concrete initiative is to organise, as is the case in France, working groups with private sector and civil society organisations to discuss platform design. 


\section{Favouring trust in the new digital economy}

Public acceptance of innovation and new technologies is in general high. Denmark has the highest share of positive views of robots and Artificial Intelligence among EU countries (European Commission, 2017 [93]). Nonetheless, fostering the diffusion of new technologies will require investments to address security and privacy issues associated with these technologies. While Danes generally have a positive attitude towards new technologies, they tend to be more concerned than the EU average by security issues and the treatment of their personal information on the Internet (Figure 32) (OECD, 2017 $7_{[17]}$; European Commission, 2017 [93]). This represents an obstacle to the uptake of new types of services enabled by the digital technologies, in particular e-commerce.

Figure 32. Use of personal information on the Internet is a concern in Denmark

As a percentage of internet users, 2016

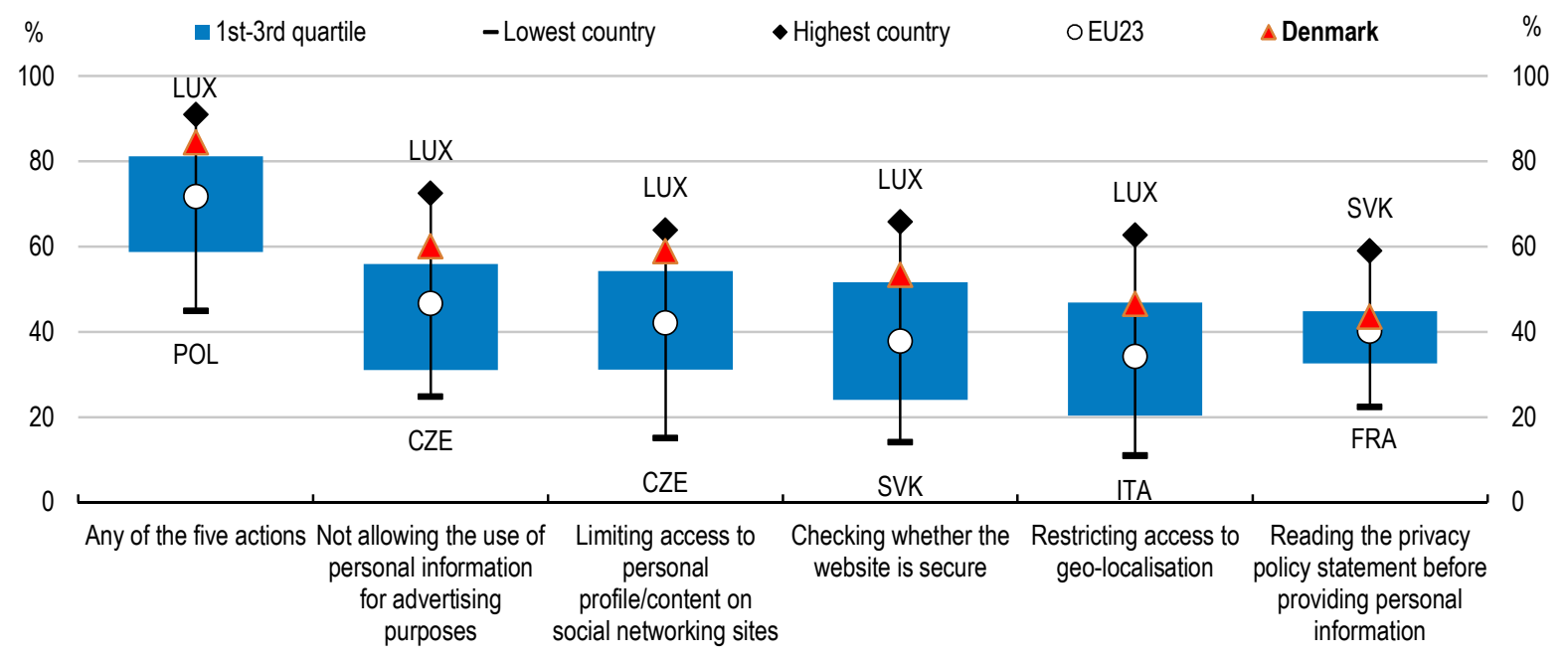

Note: The sample contains 23 EU countries covered in the Eurostat, Digital Economy and Society Statistics, Comprehensive Database and represents individuals aged 16-74. For example, in Slovakia, 60\% of internet users aged 16-74 are reading the privacy policy statement before providing personal information.

Source: OECD calculations based on OECD STI Scoreboard 2017.

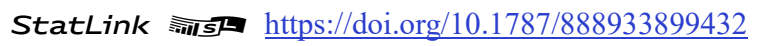

The 2018 Digital Growth reform package (Box 4) contains a number of initiatives to strengthen cyber security in companies, including the creation of a single digital point of entry for reporting of IT security incidents to public authorities. The Government also launched a national strategy for cyber and information security, focusing particularly on institutions that perform functions that are critical to society. The successful implementation of this new strategy will be crucial to increase trust in digital technologies and to pave the way for better awareness of cybersecurity issues in the business sector, which is missing especially in small firms (Figure 33). Furthermore, the Government has appointed an expert group to provide recommendations on ethical and responsible use of data by businesses and announced the intention to set up a permanent Data Ethical Council (Box 4). 
Figure 33. Formally defined security policies are mostly present in large firms

As percentage of enterprises in each employment size class, 2015

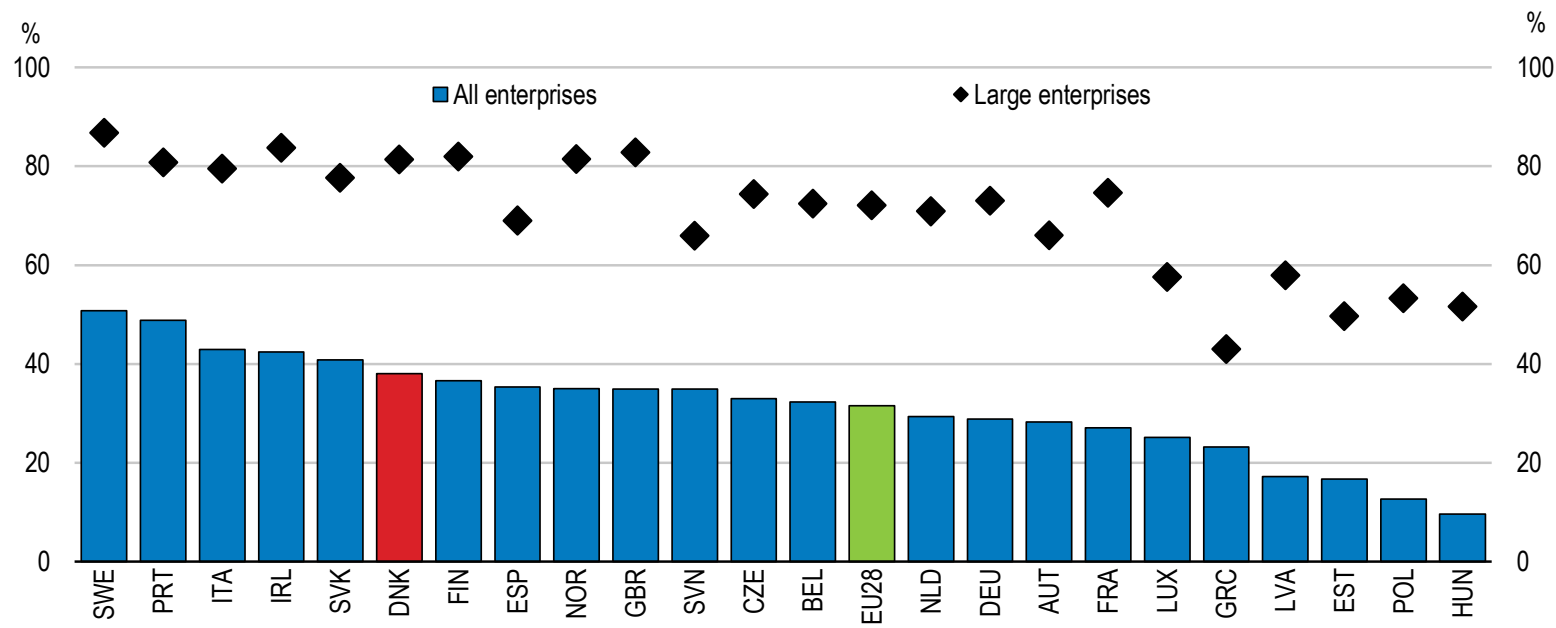

Source: OECD STI Scoreboard 2017.

StatLink त्ञाज https://doi.org/10.1787/888933899451

Overlooking the social consequences of disruptive technologies is likely to bring resistance to innovation, with uncertain political and economic consequences (OECD, 2017 ${ }_{[17]}$; Korinek and Stiglitz, 2017 [94] $)$. Trust in the new technologies can also be increased through social measures that accompany disruptions. Given its extensive welfare system, Denmark is in a good place to play a pioneering role in developing social safety nets for the new economy. Inclusion and cooperation with social partners have so far supported the digital transformation well, with for example the world's first collective agreement for the platform economy recently signed between a Danish platform for cleaning in private homes (Hilfr.dk) and the largest trade union (3F) (Fagbladet 3F, 2018 ${ }_{[95]}$ ). The Government also has a role to play and should pursue efforts to integrate these new types of business models into its tax and labour laws, as already initiated with the strategy for the collaborative economy in 2017. This approach will help increase trust and in turn facilitate the uptake of new types of services provided by these new technologies.

\section{Building skills to keep up with technological disruption}

New technologies and globalisation are changing labour markets, creating new forms of work and new skill needs in a "technology-rich environment" (Andrews and Westmore, 2014 [96]; Pellegrino and Zingales, 2017 [97]; Bloom et al., 2012 [98]), but also displacements and a need for adapting labour market policies (OECD, 2017[99]). Automation and disruptive technologies could fundamentally change many jobs in the future, albeit only a relatively low share of around $10 \%$ are estimated to face high risk of automation in Denmark (Nedelkoska and Quintini, 2018 ${ }_{[100]}$ ), reflecting the already high level of digitalisation. Polarisation of the labour market has been observed in Denmark as in most OECD countries, with indications of skill mismatches as tertiary graduates have dominated the rise in low-skill jobs (see Key Policy Insights). 


\section{Skills for the future}

New technologies and their increasing use in the business sector have in particular raised the demand for complementary skills, such as management and communication skills (OECD, 2016 [101]; OECD, 2017 [29]; OECD, 2016 [102]). The rapid pace of innovation calls for moving towards a more flexible education system. Curricula need to target the future demands of the labour market and provide students with general skills, which will enable them to adapt to a changing work environment.

Denmark is currently facing difficulties to meet labour demand for certain skills, with a comparatively low share of high-skilled labour in the private sector. Skills shortages are observed in various knowledge areas such as education and training, mathematics and computer and electronics (Figure 34$)\left(\right.$ OECD, $\left.2017_{[103]}\right)$. 
Figure 34. Knowledge areas and skills in shortage and surplus in Denmark

2015

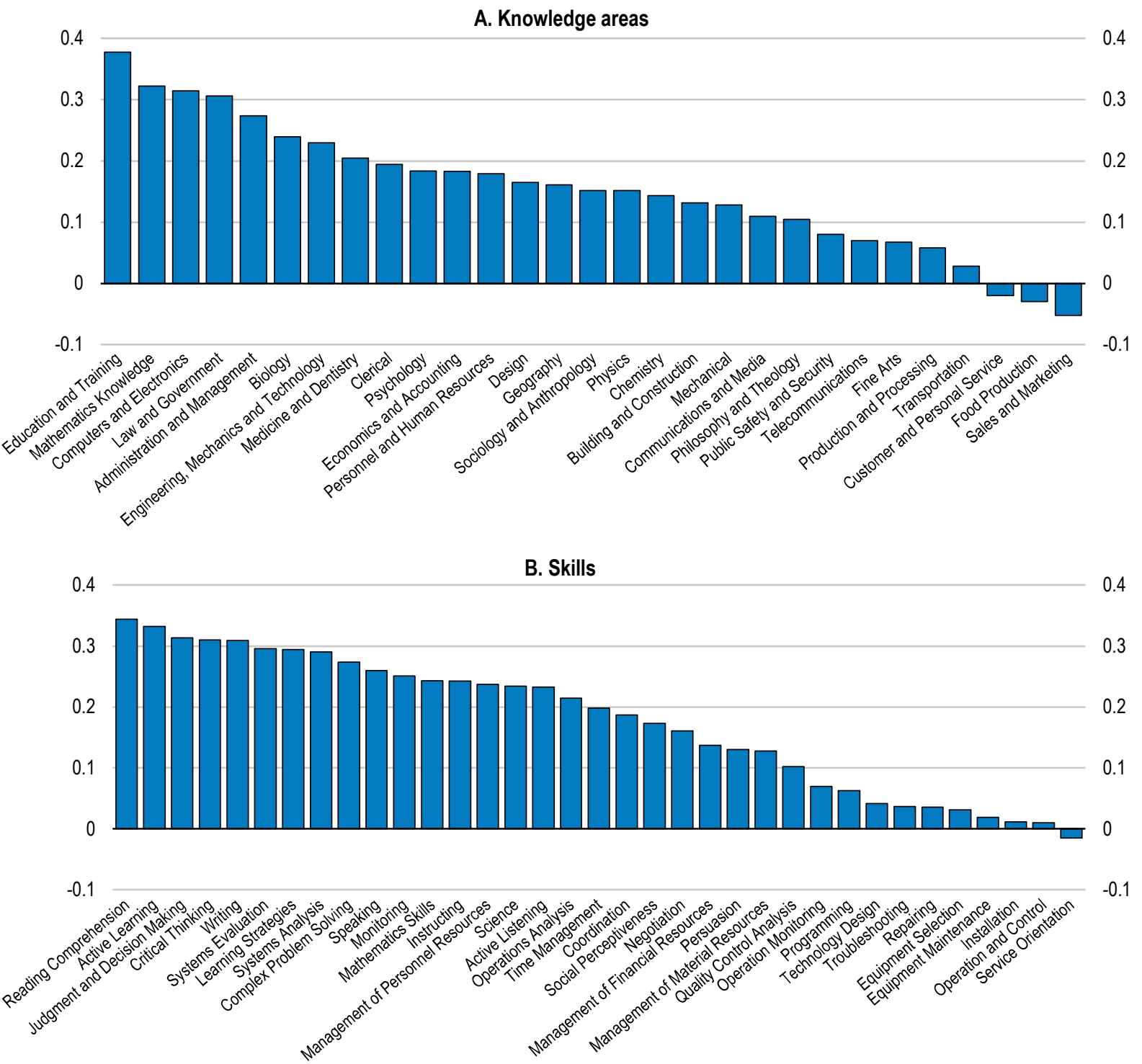

Note: Positive values represent shortages (e.g. unsatisfied demand in the labour market for the analysed dimension). Negative values represent surpluses (supply exceeds demand in the labour market for the analysed dimension). Results are presented on a scale that ranges from -1 to +1 . The maximum value represents the strongest shortage observed across OECD (31) countries and knowledge areas.

Source: OECD Skills for Jobs database (2018).

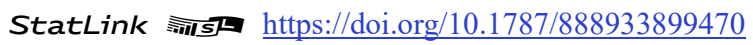

Around one fourth of all job openings in the private sector requires skills in IT and science, technology, engineering and mathematic (STEM) (Højbjerre Brauer Schultz, 2018 [104]). While the share of the adult population with tertiary education is slightly above the OECD average (OECD, 2017 $7_{[105]}$ ), fewer students are choosing STEM as their field of education than in other OECD countries (Figure 35). At the same time, a relatively high share of 
youth enters the labour market with low qualification levels (Deloitte/Kraka, 2017[73]; Maibom, Rosholm and Svarer, 2014 [106]; Andersen, 2017 [107]).

Figure 35. The share of STEM graduates is low

Tertiary educated adults with STEM as a \% of 25-64 year-old non-students, 2015 or latest available year

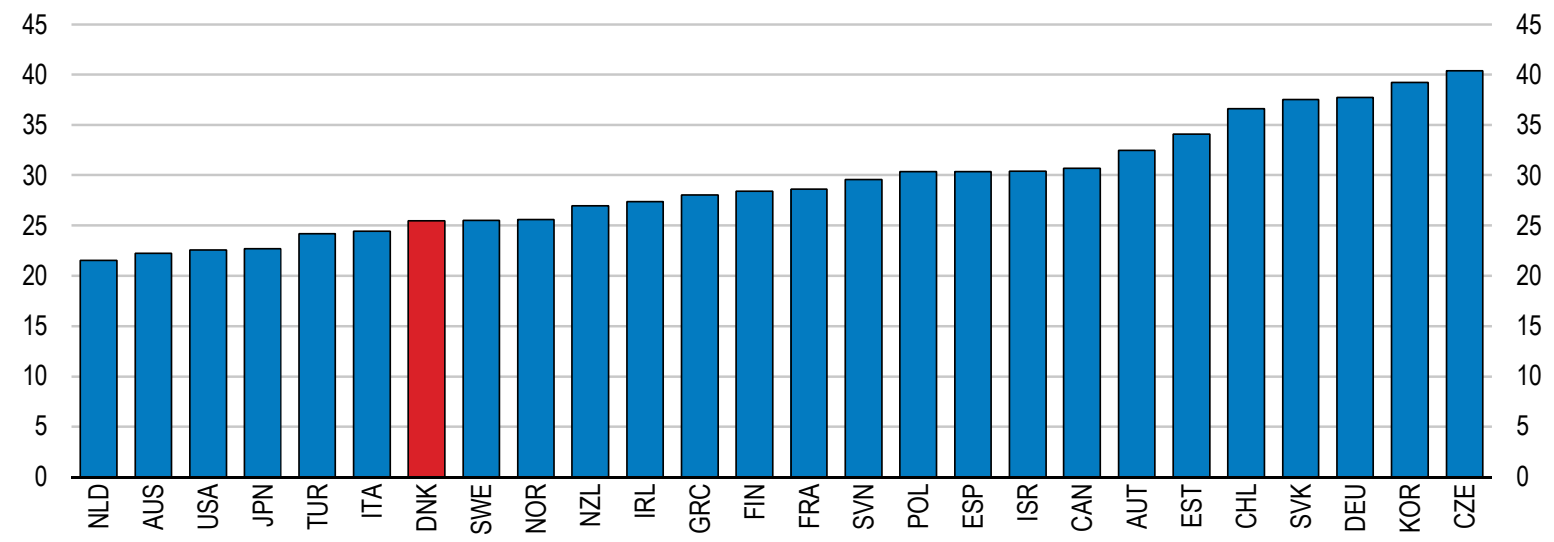

Note: STEM refers to science, technology, engineering and mathematics subjects. Source: OECD Survey of Adult Skills (PIAAC) (2013; 2016).

StatLink הत्ञाs https://doi.org/10.1787/888933899489

The share of firms facing difficulties in filling vacant positions of ICT specialists is among the highest in OECD countries (Figure 36). Businesses' difficulties to attract ICT specialists is likely related to the fact that the returns of ICT-task intensive jobs, and returns to skills in general, are low compared to other countries (Figure 37). This partly reflects the relatively low wage dispersion in Denmark and low income inequality in general. At the same time, labour market and productivity returns may also be higher in other sectors such as health and social sciences (Danish Ministry of Finance, 2014 $\left.{ }_{[108]}\right)$.

\section{Figure 36. ICT skills shortage is significant and increasing}

Percentage of firms reporting they had hard-to-fill vacancies for jobs requiring ICT specialist skills $\%$
10

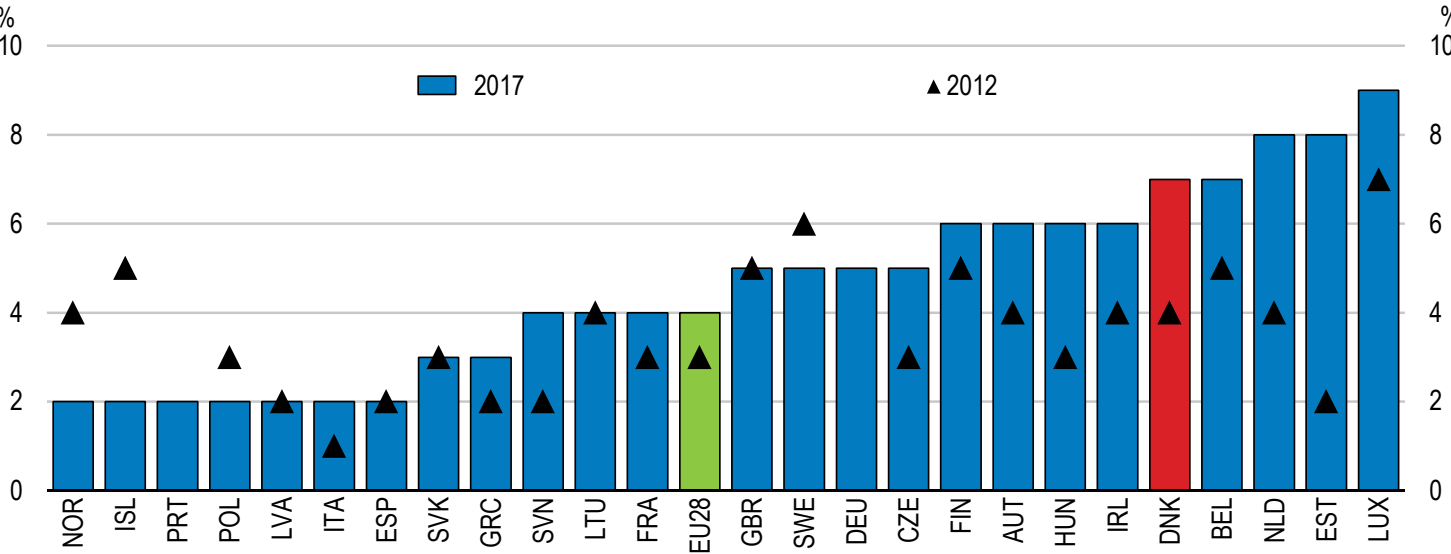

Note: All enterprises with 10 or more employees, excluding the financial sector.

Source: Eurostat, Information Society database, 2018. 
Figure 37. Labour market returns to ICT tasks are relatively low

Percentage change in hourly wages for a 10\% increase in ICT task intensity, 2012

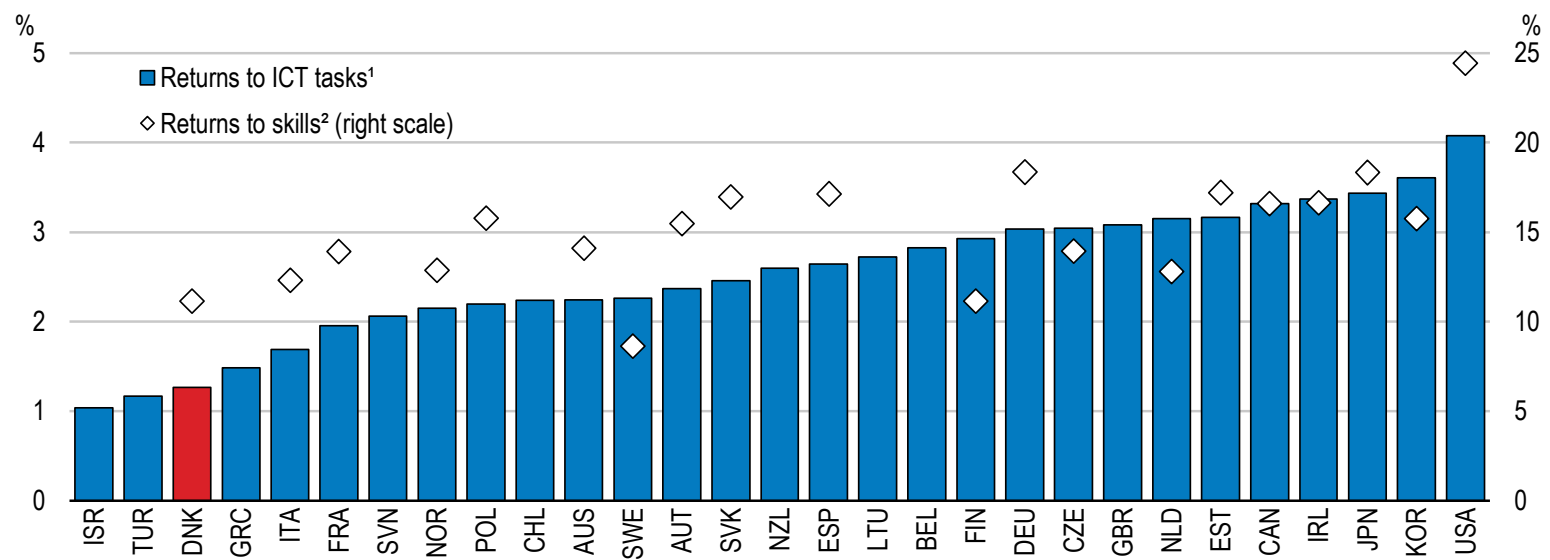

1. Percentage change in hourly wages for a $10 \%$ increase in ICT task intensity. The detailed methodology can be found in Grundke et al. (2018[109]). Labour market returns to task intensities are based on OLS wage regressions (Mincer equations) using data from the OECD Survey of Adult Skills (PIAAC).

2. Percent increase in hourly wages for a standard deviation increase in numeracy. Data show the coefficients on numeracy scores from country-specific regressions of log hourly wages (including bonuses) of wage and salary earners (in PPP corrected USD) on proficiency scores standardised at the country level.

Source: OECD STI Scoreboard 2017, based on the Survey of Adult Skills (PIAAC) database; OECD Employment Outlook 2015.

\section{StatLink त्ञातs https://doi.org/10.1787/888933899527}

Overall, a possible skill shortage of 110000 persons (around 4\% of total employment is projected by 2025 (Iversen, Stephensen and Hansen, 2016 $6_{[10]}$ ), including a shortage of workers with a vocational education. In order to address this issue, the education and tax systems need to encourage students to choose fields of education that are in line with their abilities, to complete education in a reasonable time, but also to focus on occupations in high demand. The quality and relevance of the vocational education system needs strengthening. Graduates with vocational education are on average 28 year old, among the oldest across European countries (OECD, 2017 $\left.7_{[105]}\right)$, and dropout rates are relatively high.

The Government has initiated a wide scale reflection on how to improve the education system and make it more relevant for the labour market by reforming the university funding system and better targeting labour market demand and future skill needs in education (Danish Ministry of Higher Education and Science, 2018 [111]). An agreement was passed in December 2017 to reform university funding based on quality and outcomes of students (with a basic allocation of $25 \%$ fixed upon the present budget level, an activity allocation of $67.5 \%$ and an outcome-oriented allocation of $7.5 \%$ ), which will be effective from January 2019. In April 2018, the Government also launched a Technology Pact (Box 4) aiming to raise the number of STEM graduates in collaboration with companies, educational and research institutions.

While these initiatives are welcome, they will take time to materialise into tangible outcomes. Further reforms could be considered, including raising the share of funding attributed to programmes reaching good labour market outcomes. Complementary measures on the education system would help supporting labour market demand, such as evaluating the supply of tertiary educations to simplify and reduce the large number of 
specialised entrances (currently more than 1000 programmes are offered) and providing clear information on employment opportunities for prospective students as recommended

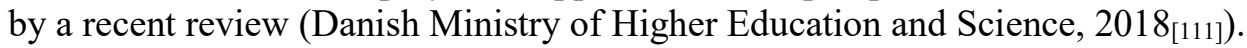

Sizeable public resources are allocated to education, elevated by the absence of tuition fees and provision of very generous student grants (830 EUR per month per student before taxes in 2019), exceeding levels in other Nordic countries. Such high levels of grants are likely to exceed the level justified by market failures and have distortive implications for society, as highlighted in recent analysis by the Danish Economic Councils $\left(2018_{[112]}\right)$. Reducing student grants and relying more on favourable student loans should be considered. Such reform could free resources for e.g. more investment in the quality of education, for instance increasing teaching hours or other measures to reduce dropout (Danish Ministry of Higher Education and Science, $2018_{[111]}$ ). It would also raise labour supply by motivating students to complete education in designated time and could enhance incentives to choose education fields in stronger demand and with higher wages.

Concerns prevail that universal access to education and social mobility would suffer from reducing student grants to higher education. Yet, analyses by the Danish Economic Councils $\left(2018_{[112]}\right)$ suggest that the impact would be very limited in Denmark, as a $10 \%$ reduction in the grants level is estimated to only reduce the share completing tertiaryeducation from $75 \%$ to $74.7 \%$ of the group of youth having completed upper secondary school. To secure equal access to education for all and avoiding indebtedness, an extended repayment period linked to subsequent income and labour market status could be considered as in e.g. Australia and the New Zealand (OECD, $\left.2017_{[105]}\right)$. The Government has recently established an expert group, which will examine the grant system and its effect on educational attainment and social mobility, expected to finish its work during 2019.

\section{Ensuring effective upskilling and lifelong learning}

Fostering upskilling and lifelong learning is critical to help employees at risk of automation or disruptive change to acquire the new skills needed, which are likely to be different from the ones acquired in past training and accumulated firm-specific human capital (Nedelkoska and Quintini, 2018 $8_{[100]}$ ). The participation rate of Denmark's adult population in lifelong learning (formal or non-formal education and training) remains among the highest in the OECD countries, but it has been decreasing over the past five years, falling behind other Nordic countries (Figure 38). While this might indicate low incentives for the unemployed to undertake training in a context where employment opportunities improve, it is crucial to continue efforts and to cooperate with employers to maintain high participation in lifelong learning in a cost-efficient way. In this view, the tripartite agreement reached between the Government and social partners in October 2017 to build a strengthened and more flexible adult education and training system is welcome (see Key Policy Insights). 
Figure 38. Participation in life-long learning is high but decreasing

Percentage of adult population (age 25 to 64 ) participating in learning

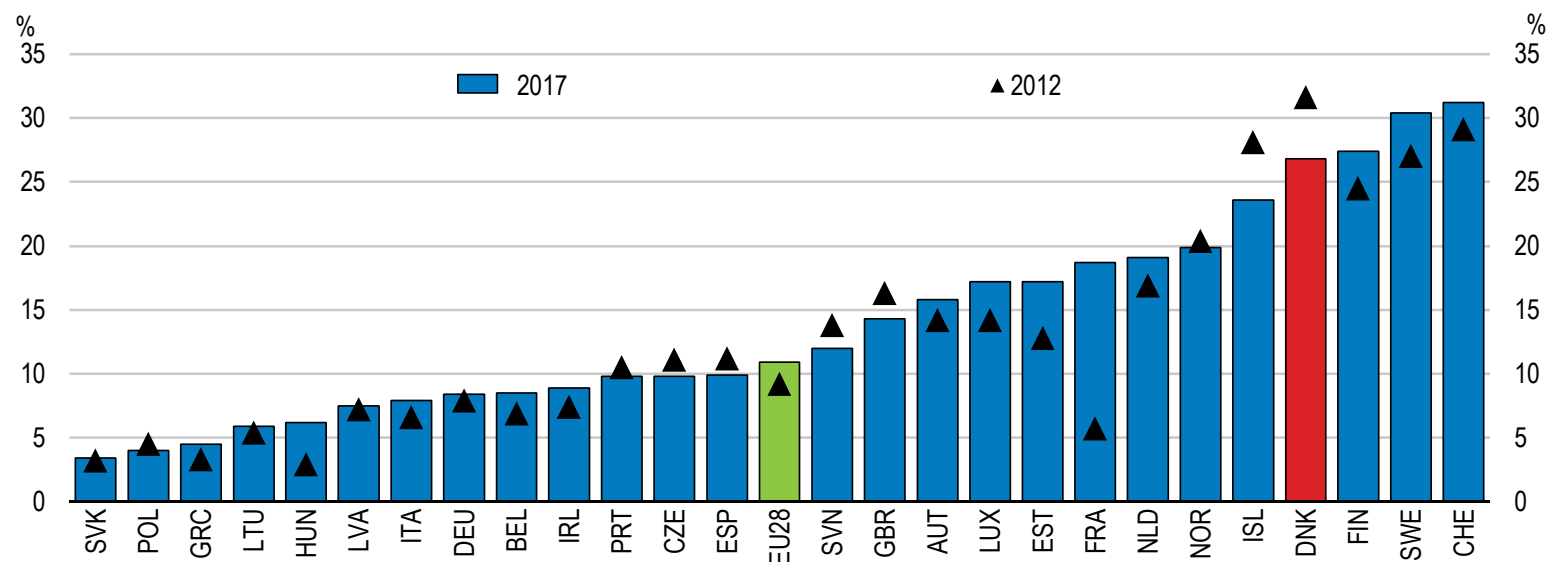

Note: The indicator measures the share of the population aged 25 to 64 who stated that they received formal or non-formal education and training in the four weeks preceding the survey (numerator). The denominator consists of the total population of the same age group, excluding those who did not answer to the question 'participation in education and training'. Adult learning covers formal and non-formal learning activities, both general and vocational, undertaken by adults after leaving initial education and training.

Source: Eurostat, based on the EU Labour Force Survey.

StatLink Ants https://doi.org/10.1787/888933899546

\section{Easing access to skilled foreign workers}

Danish firms are increasingly relying on foreign workers to satisfy labour demand. The number of immigrants who have come to Denmark for work reasons has increased significantly since the 2000 s, which has played an important role in avoiding the capacity constraints experienced in previous upturns (see Key Policy Insights). These foreign workers are mainly EU citizens who can reside and work in Denmark under EU regulations

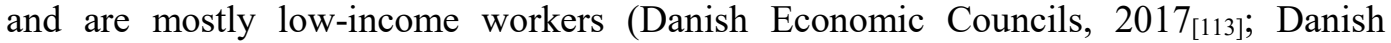
Ministry for Economic Affairs and the Interior, 2017 $\left.{ }_{[114]}\right)$. However, as economic conditions have improved, especially in Eastern European countries, recruitment is becoming more difficult. Attracting high-skilled foreign workers, from EU and non-EU countries, is essential as it not only can help to address the skills shortage, but may also boost productivity within firms (Malchow-Møller, Munch and Skaksen, 2017 [115]).

Restrictions on access for non-EU workers have contributed to raise the average qualification profile of immigrants. For example, $44 \%$ of foreign-born adults were tertiary educated in 2017 (Figure 39). Nonetheless, the proportion of high-skilled immigrants in the working-age population remains relatively low compared to other countries. The proportion of foreign-born workers with a tertiary education is similar to Sweden, but in total they represent a much higher share of the working-age population in Sweden $(12 \%$ versus 6\%) (Figure 39). 
Figure 39. A large proportion of foreign-born adults are highly educated, but they represent a small proportion of the total population

Tertiary-educated foreign-born adults, 2017

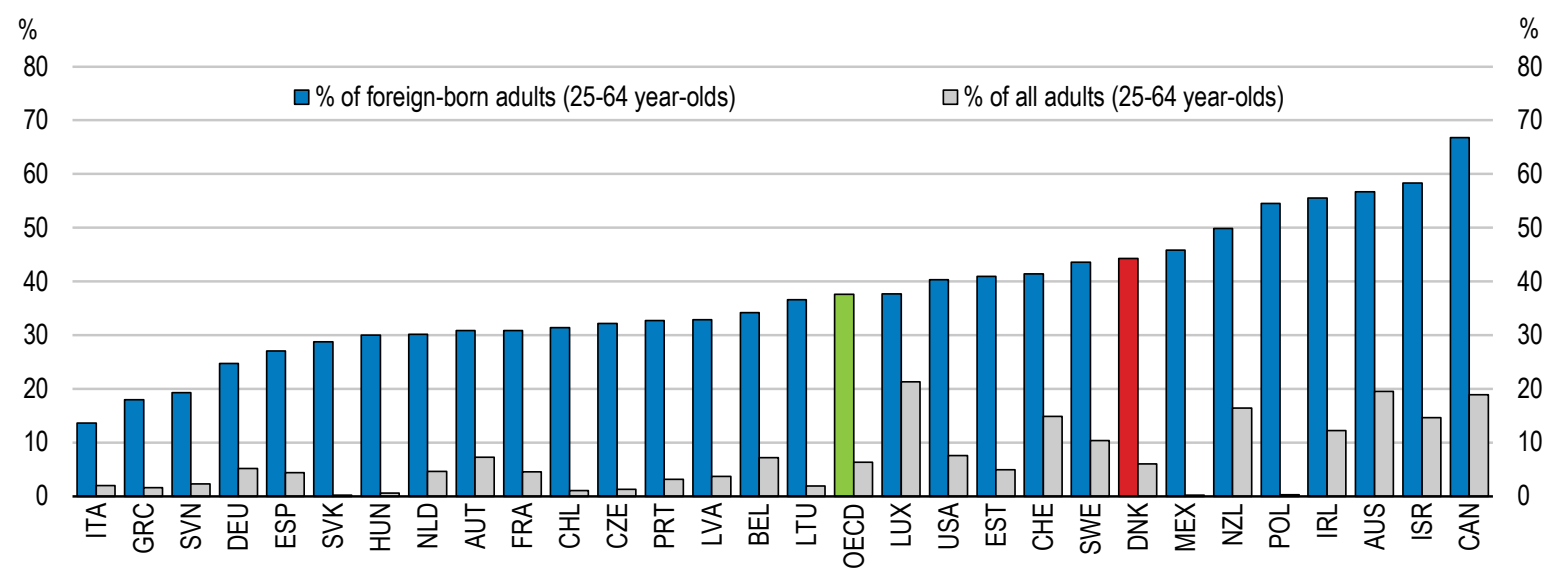

Source: Calculations based on OECD Education at a Glance 2018.

StatLink 제으 https://doi.org/10.1787/888933899565

Recent policy changes have tightened the entry conditions for non-EU workers. In 2016, the Green Card scheme was abolished and the wage floor for entering through the "Pay Limit Scheme" was raised (beløbsordningen, allowing access to the Danish labour market to foreigners who have been offered a job with a yearly salary of minimum EUR 57000 without any requirement on educational background or professional field). Stricter rules for salary calculation (exclusion of fringe benefits) and additional requirements to use a Danish bank account were introduced in 2017, which tend to significantly raise the administrative burden on firms and workers. Preliminary evaluations show that the two tightenings have resulted in a decline in entry and procedures have become more lengthy and complicated (Danish Ministry of Finance, 2018 ${ }_{[116]}$; Danish Ministry of Immigration and Integration, $\left.2018_{[117]}\right)$. In addition, instability in the legislation creates uncertainty for foreigners who envisage working in Denmark as well as for the firms who envisage recruiting them.

The Government is currently exploring options for revising the visa schemes to ease access for high-skilled non-EU workers. Other countries have moved in the same direction by loosening entry conditions on existing schemes or creating new ones (OECD, 2017 ${ }_{[118]}$ ). For example, in Japan the waiting period for permanent residence has been reduced for topscoring foreigners in its points-based system. Recent changes have also been introduced to attract investors and entrepreneurs in Australia, Canada, Chile, France, Korea, Spain and New Zealand.

In a context of tightening capacity constraints and ageing, incentives to attract foreign workers should be strengthened. Denmark should assess whether the current visa schemes for non-EU workers sufficiently address skill needs and take necessary steps. The Pay Limit Scheme is the most used, reaching 6000 permits in 2017, yet the visa permit system offers a number of options, which may be simplified and made more efficient. In this context, lowering the top marginal income tax rate, as discussed above, would also raise the incentives for high-skilled foreign workers to come and work in Denmark. 
Box 9. Recommendations

(Key recommendations are in bolded text)

Competition and regulation

- Provide greater power to competition authorities to impose administrative fines and structural remedies within constitutional constraints.

- Develop clearer standards for exemptions from the Competition Act and involve competition authorities in their determination.

- Proceed with revisions of regulatory frameworks to make them technology-neutral and monitor fast evolving sectors to swiftly respond to emerging market failures.

Taxation and access to finance

- Reduce top marginal tax rates on labour and capital incomes. Withdraw reduced inheritance taxation for family-owned businesses.

- Implement an allowance for corporate equity (ACE) in the corporate income tax, accompanied by a sufficient anti-avoidance framework.

- Review financial regulation for pension funds to remove barriers for investments in the domestic equity market, including innovative startups and SMEs through investment funds.

Innovation

- Broaden public support to business $R \& D$ through well-designed $R \& D$ grants and tax credits for incremental $R \& D$ expenses.

- Improve collaboration between universities and businesses by reducing the complexity of the system regulating cooperation, and improving intellectual property right policies of universities.

Technology adoption

- Deploy key enabling technology standards in the public sector and make government data more available and usable.

- Raise awareness and education for digital risk management in businesses.

Skills

- Reduce student grants for tertiary education and rely more on student loans. Link repayment conditions to subsequent income and labour market status.

- Assess whether the current visa schemes for non-EU workers sufficiently address skill needs and consider simplifying entry procedures. 


\section{References}

Adalet McGowan, M., D. Andrews and V. Millot (2017), "Insolvency Regimes, Technology Diffusion and Productivity Growth: Evidence from Firms in OECD Countries", OECD Economics Department Working Papers, No. 1425, OECD Publishing, Paris, http://dx.doi.org/10.1787/36600267-en.

Albrizio, S. et al. (2014), "Do Environmental Policies Matter for Productivity Growth? Insights from New Cross-Country Measures of Environmental Policies", OECD Economics Department Working Papers, No. 1176, OECD Publishing, Paris, https://doi.org/10.1787/5jxrjncjrcxp-en.

Andersen, T. (2017), “The Danish labor market, 2000-2016”, IZA World of Labor, No. 404.

Andrews, D., C. Criscuolo and P. Gal (2016), "The Best versus the Rest: The Global Productivity Slowdown, Divergence across Firms and the Role of Public Policy", OECD Productivity Working Papers, No. 5, OECD Publishing, Paris, http://dx.doi.org/10.1787/63629cc9-en.

Andrews, D., C. Criscuolo and P. Gal (2015), "Frontier Firms, Technology Diffusion and Public Policy: Micro Evidence from OECD Countries", OECD Productivity Working Papers, No. 2 , https://doi.org/10.1787/5jrq12q2jj7b-en.

Andrews, D., G. Nicoletti and C. Timiliotis (2018), "Digital technology diffusion: A matter of capabilities, incentives or both?", OECD Economics Department Working Papers, No. 1476, OECD Publishing, Paris, http://dx.doi.org/10.1787/7c542c16-en.

Andrews, D. and B. Westmore (2014), "Managerial Capital and Business R\&D as Enablers of Productivity Convergence", OECD Economics Department Working Papers, No. 1137, OECD Publishing, Paris, http://dx.doi.org/10.1787/5jxx3d441knr-en.

Appelt, S. et al. (2016), "R\&D Tax Incentives: Evidence on design, incidence and impacts", OECD Science, Technology and Industry Policy Papers, No. 32, OECD Publishing, Paris, http://dx.doi.org/10.1787/5jlr8fldqk7j-en.

Arquié, A., L. Demmou and I. Stefanescu (2018), "Labour Productivity Growth and Finance: The Role of Intangible Assets", OECD Economics Department Working Papers, No. forthcoming, OECD Publishing, Paris.

Bennedsen, M. and K. Nielsen (2016), Ejerledelse i Danmark: De økonomiske konsekvenser af ejerskifte i Danmark (Governance of family firms in Denmark: The economic consequences of ownership change in Denmark), Copenhagen Business School.

Berlingieri, G., P. Blanchenay and C. Criscuolo (2017), "The great divergence(s)", OECD Science, Technology and Industry Policy Papers, No. 39, OECD Publishing, Paris, http://dx.doi.org/10.1787/953f3853-en. 
Berlingieri, G., S. Calligaris and C. Criscuolo (2018), "The Productivity-Wage Premium: Does Size Still Matter in a Service Economy?", AEA Papers and Proceedings, Vol. 108, pp. 328333.

Bessen, J. (2017), "Information Technology and Industry Concentration", Boston School of Law, Law and Economics Research Paper, No. 14-41.

Bloom, N. et al. (2012), "Management Practices Across Firms and Countries", NBER Working Papers, No. 17850.

Bloom, N. and J. Van Reenen (2010), "Why Do Management Practices Differ across Firms and Countries?", Journal of Economic Perspectives, Vol. 24/1, pp. 203-224.

Bravo-Biosca, A., C. Criscuolo and C. Menon (2016), "What drives the dynamics of business growth?”, Economic Policy, Vol. 31/88, pp. 703-742.

Busom, I., B. Corchuelo and E. Martinez-Ros (2014), "Tax incentives... or subsidies for business R\&D?”, Small Business Economics, Vol. 43, pp. 571-596.

Calligaris, S., C. Criscuolo and L. Marcolin (2018), "Mark-ups in the Digital Era", OECD Science, Technology and Industry Working Papers, No. 2018/10, OECD Publishing, Paris, http://dx.doi.org/10.1787/4efe2d25-en.

Calvino, F., C. Criscuolo and C. Menon (2016), "No Country for Young Firms?: Start-up Dynamics and National Policies", OECD Science, Technology and Industry Policy Papers, No. 29, OECD Publishing, Paris, http://dx.doi.org/10.1787/5jm22p40c8mw-en.

Copenhagen Economics (2018), Analysis of market conditions and competitiveness in the Danish market for micro IPOs, Copenhagen.

Copenhagen Economics (2016), Gevinster for Danmark ved reduktion i barrierer for børsnoteringer og øvrig risikovillig kapital (Returns to Denmark from reductions in barriers for IPOs and other risk capital), Copenhagen.

Cour des comptes (2015), La dépense fiscale ISF-PME, Paris.

CPB (2014), "A Study on R\&D Tax Incentives: Final report”, European Commission Taxation Papers, No. 52, Luxembourg.

Crouzet, N. and J. Eberly (2018), Understanding Weak Capital Investment: The Role of Market Concentration and Intangibles, Paper presented at the Jackson Hole Economic Policy Symposium, August 2018.

Danish Economic Councils (2018), Dansk Økonomi, forår 2018 (Danish Economy, Spring 2018), Copenhagen.

Danish Economic Councils (2017), Dansk Økonomi, forår 2017 (Danish Economy, Spring 2017), Copenhagen.

Danish Economic Councils (2017), Produktivitet 2017 (Productivity 2017), Copenhagen. 
Danish Economic Councils (2016), Dansk Økonomi, efterår 2016 (Danish Economy, Fall 2016), Copenhagen.

Danish Entrepreneurship Panel (2017), Anbefalinger til regeringen (Recommendations to the Government), Copenhagen.

Danish Government (2018), Redegørelse om vaekst og konkurrenceevne 2018 (Report on Growth and Competition 2018), Copenhagen.

Danish Government (2017), Aftale om erhvervs- og ivcerkscetterinitiativer (Agreement on business and entrepreneurship initiatives), Copenhagen.

Danish Government (2017), Kommissorium for Disruptionsrådet - Partnerskab for Danmarks fremtid (Mandate of the Disruption Council - A partnership for Denmark's future), Copenhagen.

Danish Growth Fund (2018), Benchmark af venturemarkedet 2018 (Benchmark of the venture captial market 2018), Hellerup.

Danish Ministry for Economic Affairs and the Interior (2017), Økonomisk Redegørelse, December 2017 (Economic Survey, December 2017), Copenhagen.

Danish Ministry of Business and Growth (2012), Rapport fra Udvalget om erhvervsobligationer som finansieringskilde for små og mellemstore virksomheder (Report on corporate bonds as a financing source for SMEs).

Danish Ministry of Finance (2018), "Analyser af ordninger til international rekruttering (Analysis of schemes for international recruitment)", Økonomisk Analyse, Copenhagen.

Danish Ministry of Finance (2017), "BNP-virkning ved ACE (GDP effect of an ACE)", Økonomisk Analyse, Copenhagen.

Danish Ministry of Finance (2016), "Produktivitet og konkurrence (Productivity and Competition)", Økonomisk Analyse, Copenhagen.

Danish Ministry of Finance (2014), Finansredegørelse 2014 (Economic Report 2014), Copenhagen.

Danish Ministry of Higher Education and Science (2018), Danmark - klar til fremtiden: Regeringens mål for dansk forskning og innovation (Denmark - Ready to seize future opportunities), Copenhagen.

Danish Ministry of Higher Education and Science (2018), Udvalg om bedre universitetsuddannelser: Universitetsuddannelser til fremtiden (Report from Committee on Better University Educations), Copenhagen.

Danish Ministry of Immigration and Integration (2018), Erfaringsopsamling efter cendring af beløbsordningen den 1. juli 2017 (Experiences after the change of the Pay Limit Scheme by 1 July 2017), Copenhagen. 
Danish Ministry of Industry Business and Financial Affairs (2017), "Digitalisering og produktivitet - Vækstpotentiale i danske virksomheder (Digitalisation and Productivity)", Erhvervs- og vakstpolitisk analyse.

Danish Ministry of Taxation (2018), Skatteøkonomisk Redegørelse 2018 (Tax Report 2018), Copenhagen.

Danish Productivity Commission (2014), Skat og produktivitet (Tax and Productivity), Copenhagen.

Danish Productivity Commission (2013), Danmarks produktivitet - hvor er problemerne? (Denmark's Productivity - Where Are the Problems?), Copenhagen.

Danish Productivity Commission (2013), Konkurrence, internationalisering og regulering (Competition, Internationalisation and Regulation), Copenhagen.

Danmarks Nationalbank (2017), "Danes are Front-Runners in Electronic Payments", Analysis, No. 6, Danmarks Nationalbank, Copenhagen.

Danmarks Nationalbank (2016), Danske udstedelser af erhvervsobligationer er på niveau med euroomrädet (Danish corporate bond issues are close to the euro area level).

De Mooij, R. (2012), "Tax Biases to Debt Finance: Assessing the Problem, Finding Solutions", Fiscal Studies, Vol. 33/4, pp. 489-512.

Deloitte/Kraka (2017), Small Great Nation - Muligheder og udfordringer (Small Great Nation Opportunities and challenges).

Égert, B. and A. Vindics (2018), "Mark-ups and Product Market Regulation in OECD Countries: What do the Data Whisper?", mimeo.

European Commission (2018), Country Report Denmark 2018.

European Commission (2018), European Innovation Scoreboard 2018.

European Commission (2018), Regulated professions database, http://ec.europa.eu/growth/toolsdatabases/regprof/.

European Commission (2017), "Investment in the EU Member States: An Analysis of Drivers and Barriers", European Economy, Institutional Paper, No. 062, Brussels.

European Commission (2017), Special Eurobarometer 460: "Attitudes towards the impact of digitisation and automation on daily life".

European Investment Bank (2017), EIB Investment Report 2017/2018: From recovery to sustainable growth, Luxembourg.

Fagbladet 3F (2018), "Historisk overenskomst: Rengøringsplatform indgår overenskomst med $3 \mathrm{~F}$ (Historical collective agreement: Cleaning platform reaches agreement with United Federation of Danish Workers)". 
Financial Supervisory Authority (2017), Markedsudvikling 2016: Livsforsikringsselskaber og tvcergående pensionskasser (Market development 2016), Copenhagen.

Fosse, H., J. Jacobsen and A. Sørensen (2013), ICT, Innovation and Productivity Growth, Copenhagen Business School.

Gordon, R. (2012), "Is U.S. Economic Growth Over? Faltering Innovation Confronts the Six Headwinds", NBER Working Paper, No. 18315.

Grimpe, C. and J. Mitchell (2016), RIO country report 2015: Denmark, European Commission, Luxembourg.

Grundke, R. et al. (2018), "Which skills for the digital era?: Returns to skills analysis", $O E C D$ Science, Technology and Industry Working Papers, No. 2018/09, OECD Publishing, Paris, http://dx.doi.org/10.1787/9a9479b5-en.

Havrylchyk, O. (2018), "Regulatory Framework for the Loan-Based Crowdfunding Platforms", OECD Economics Department Working Papers, No. 1513, OECD Publishing, Paris, http://dx.doi.org/10.1787/24ad924a-en.

Hebous, S. and M. Ruf (2017), "Evaluating the effects of ACE systems on multinational debt financing and investment", Journal of Public Economics, Vol. 156, pp. 131-149.

Hersaeus, E. and R. Svahn (2011), "Deploying IPv6-Internet Protocol version 6 Practical guidance", Swedish Post and Telecom Agency Report, No. 2011:18, Stockholm.

Højbjerre Brauer Schultz (2018), Virksomheders efterspørgsel efter STEM-kompetencer (Firms' demand for STEM skills), Copenhagen.

Højbjerre Brauer Schultz (2017), Barrierer for virksomheders dataanvendelse (Barriers for use of data by businesses), Copenhagen.

IMF (2018), "Capital Income Tax Reform Options in Denmark", IMF Country Report, No. $18 / 178$.

IMF (2018), "Investment Slowdown in Denmark: Diagnosis and Policy Option", IMF Country Report, No. 18/178.

Insurance and Pension (2018), Investeringspolitisk redegørelse (Investment Policy Report), Hellerup.

Invest Europe (2018), European Private Equity Activity Report 2017.

Irisgroup (2015), Midtvejsevaluering af Markedsmodningsfonden (Mid-term evaluation of the Market Development Fund).

Iversen, A., P. Stephensen and J. Hansen (2016), Mismatch på det danske arbejdsmarked (Mismatches in the Danish labour market), DREAM report, Copenhagen. 
Johnstone, N. and T. Kozluk (2018), "Effects of Vintage-Differentiated Environmental Regulations: Evidence from Survival Analysis of Coal-Fired Power Plants", OECD Economics Department Working Papers, No. forthcoming, OECD Publishing, Paris.

Korinek, A. and J. Stiglitz (2017), "Artificial Intelligence and Its Implications for Income Distribution and Unemployment", NBER Working Paper, No. 24174.

Kreiner, C., J. Munch and H. Whitta-Jacobsen (2015), "Taxation and the long run allocation of labor: Theory and Danish evidence”, Journal of Public Economics, Vol. 127, pp. 74-86.

Kristoffersen, M., M. Spange and S. Malthe-Thagaard (2017), "Diffusion of new knowledge benefits firms' productivity", Analysis, No. 18, Danmarks Nationalbank, Copenhagen.

Maibom, J., M. Rosholm and M. Svarer (2014), "Can Active Labour Market Policies Combat Youth Unemployment?”, Nordic Economic Policy Review, pp. 217-256.

Malchow-Møller, N., J. Munch and J. Skaksen (2017), "Do Foreign Experts Increase the Productivity of Domestic Firms?", Scandinavian Journal of Economics, Vol. forthcoming.

Malchow-Møller, N., J. Munch and J. Skaksen (2015), "Services trade, goods trade and productivity growth: evidence from a population of private sector firms", Review of World Economics, Vol. 151/2, pp. 197-229.

Mirrlees, J. et al. (2011), Tax by Design: The Mirrlees Review, Oxford University Press, Oxford.

Nedelkoska, L. and G. Quintini (2018), "Automation, skills use and training", OECD Social, Employment and Migration Working Papers, No. 202, OECD Publishing, Paris, http://dx.doi.org/10.1787/2e2f4eea-en.

OECD (2018), Achieving Inclusive Growth in the Face of Digital Transformation and the Future of Work, OECD report to G-20 Finance Ministers, http://www.oecd.org/g20/summits/buenosaires/OECD Achieving $\% 20$ inclusive $\% 20$ growth $\% 20$ in $\% 20$ the $\% 20$ face $\% 20$ of $\% 20$ FoW.pdf.

OECD (2018), Competition Assessment in Light of Digitalisation: A Synthesis, OECD, Paris.

OECD (2018), Financing SMEs and Entrepreneurs 2018: An OECD Scoreboard, OECD Publishing, Paris, http://dx.doi.org/10.1787/fin_sme_ent-2018-en.

OECD (2018), Going Digital: Making the transformation work for growth and well-being, http://www.oecd.org/going-digital/.

OECD (2018), OECD Economic Surveys: Germany 2018, OECD Publishing, Paris, http://dx.doi.org/10.1787/eco surveys-deu-2018-en.

OECD (2018), Tax Challenges Arising from Digitalisation - Interim Report 2018: Inclusive Framework on BEPS, OECD/G20 Base Erosion and Profit Shifting Project, OECD Publishing, Paris, http://dx.doi.org/10.1787/9789264293083-en.

OECD (2018), Taxi, ride-sourcing and ride-sharing services - Note by Denmark, OECD, Paris. 
OECD (2017), Algorithms and Collusion: Competition Policy in the Digital Age, OECD

Publishing, Paris, http://www.oecd.org/daf/competition/Algorithms-and-colllusioncompetition-policy-in-the-digital-age.pdf.

OECD (2017), Education at a Glance 2017: OECD Indicators, OECD Publishing, Paris, http://dx.doi.org/10.1787/eag-2017-en.

OECD (2017), Getting Skills Right: Skills for Jobs Indicators, Getting Skills Right, OECD Publishing, Paris, http://dx.doi.org/10.1787/9789264277878-en.

OECD (2017), International Migration Outlook 2017, OECD Publishing, Paris, http://dx.doi.org/10.1787/migr_outlook-2017-en.

OECD (2017), Key Issues for Digital Transformation in the G20, Report prepared for a joint G20 German Presidency/OECD conference, http://www.oecd.org/sti/ieconomy/key-issuesfor-digital-transformation-in-the-g20.pdf.

OECD (2017), OECD Digital Economy Outlook 2017, OECD Publishing, Paris, http://dx.doi.org/10.1787/9789264276284-en.

OECD (2017), OECD Economic Surveys: Belgium 2017, OECD Publishing, Paris, http://dx.doi.org/10.1787/eco surveys-bel-2017-en.

OECD (2017), OECD Economic Surveys: Switzerland 2017, OECD Publishing, Paris, http://dx.doi.org/10.1787/eco surveys-che-2017-en.

OECD (2017), OECD Employment Outlook 2017, OECD Publishing, Paris, http://dx.doi.org/10.1787/empl outlook-2017-en.

OECD (2017), OECD Science, Technology and Industry Scoreboard 2017: The digital transformation, OECD Publishing, Paris, http://dx.doi.org/10.1787/9789264268821-en.

OECD (2016), Big Data: Bringing Competition Policy to the Digital Era, OECD Competition Committee Background Note, http://www.oecd.org/daf/competition/big-data-bringingcompetition-policy-to-the-digital-era.htm.

OECD (2016), Getting Skills Right: Assessing and Anticipating Changing Skill Needs, Getting Skills Right, OECD Publishing, Paris, http://dx.doi.org/10.1787/9789264252073-en.

OECD (2016), OECD Economic Surveys: Denmark 2016, OECD Publishing, Paris, http://dx.doi.org/10.1787/eco_surveys-dnk-2016-en.

OECD (2016), OECD Science, Technology and Innovation Outlook 2016, OECD Publishing, Paris, https://doi.org/10.1787/sti in outlook-2016-en.

OECD (2016), "Skills for a Digital World: 2016 Ministerial Meeting on the Digital Economy Background Report", OECD Digital Economy Papers, No. 250, OECD Publishing, Paris, http://dx.doi.org/10.1787/5jlwz83z3 wnw-en. 
OECD (2015), Competition Law and Policy in Denmark: A Peer Review, OECD Publishing, Paris, http:/www.oecd.org/daf/competition/COMP A\%20Peer\%20Review Denmark web 2015. pdf.

OECD (2015), OECD Science, Technology and Industry Scoreboard 2015, OECD Publishing, Paris, https://doi.org/10.1787/sti scoreboard-2015-en.

OECD (2014), "The Economics of Transition to Internet Protocol version 6 (IPv6)", OECD Digital Economy Papers, No. 244, OECD Publishing, Paris, http://dx.doi.org/10.1787/5jxt46d07bhc-en.

OECD (2013), OECD Economic Surveys: Denmark 2013, OECD Publishing, Paris, http://dx.doi.org/10.1787/eco surveys-dnk-2013-en.

Pellegrino, B. and L. Zingales (2017), "Diagnosing the Italian Disease”, NBER Working Papers, No. 23964.

Rajan, R. and L. Zingales (1998), "Financial Dependence and Growth", American Economic Review, Vol. 88/3, pp. 559-586.

Smeets, V. and F. Warzynski (2018), "The Effect of ICT on Industry Dynamics, Firm Growth and Productivity", OECD Economics Department Working Papers, No. forthcoming, OECD Publishing, Paris.

Statistics Denmark (2018), IT-anvendelse i virksomheder 2017: Virksomhedernes digitalisering (ICT use in enterprises 2017: Digitalisation), Copenhagen.

Thompson, J. and K. Boschmans (2018), “Alternative Financing Instruments for SMEs and Entrepreneurs: The case of capital market finance", OECD SME and Entrepreneurship Papers, No. 10, OECD Publishing, Paris, http://dx.doi.org/10.1787/dbdda9b6-en.

Thum-Thysen, A. et al. (2017), "Unlocking Investment in Intangible Assets", European Economy Discussion Paper, No. 047.

Zangari, E. (2014), "Addressing the Debt Bias: A Comparison between the Belgian and the Italian ACE Systems", European Commission Taxation Papers, No. 44, Luxembourg.

ZEW (2016), "The Effects of Tax Reforms to Address the Debt-Equity Bias on the Cost of Capital and on Effective Tax Rates", European Commission Taxation Papers, No. 65, Luxembourg. 